(C) 2018. This manuscript version is made available under the CC-BY-NC-ND 4.0 license http:// creativecommons.org/licenses/by-nc-nd/4.0/

\title{
A depositional model for spherulitic carbonates associated with
}

\section{alkaline, volcanic lakes}

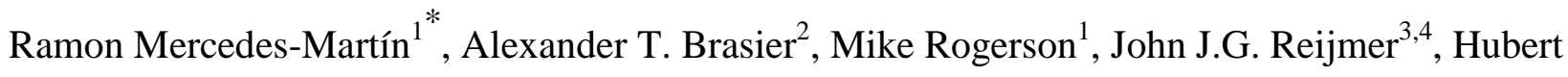 \\ Vonhof $^{5}$ and Martyn Pedley ${ }^{1}$
}

1. School of Environmental Sciences, University of Hull, Cottingham Road, HU6 7RX, Hull, UK. (* Email: r.mercedes@hull.ac.uk).

2. School of Geosciences, Meston Building, University of Aberdeen, Old Aberdeen, Scotland, UK. AB24 3UE.

3. Faculty of Earth and Life Sciences, VU University of Amsterdam, De Boelelaan 1085, 1081HV Amsterdam, The Netherlands.

4. College of Petroleum Engineering and Geosciences, King Fahd University of Petroleum and Minerals, Dhahran 31261, Saudi-Arabia

5. Max Planck Institut für Chemie, Hahn-Meitnerweg 1, 55128 Mainz, Germany.

\begin{abstract}
The South Atlantic Aptian 'Pre-salt' reservoirs are formed by a combination of spherulitic carbonates and $\mathrm{Mg}$-rich clays accumulated in volcanic alkaline lake settings with exotic chemistries. So far, outcrop analogues characterised by metre-thick successions deposited in lacustrine scenarios are elusive so disentangling the genesis of spherulitic carbonates represents a major scientific challenge with business impact. In particular the controls on spatial distribution and the environment of spherulitic facies formation remain poorly constrained, little studied, and hotly debated. To shed light on this conundrum, a spherulitic carbonate-rich, alkaline volcanic lacustrine succession has been analysed at outcrop scale: the Carboniferous East Kirkton Limestone (Scotland). Despite clays being very scarce and limited to layers of amorphous $\mathrm{Mg}$-Si minerals, a diverse array of spherulitic calcitic
\end{abstract}


components were formed, including coated grains, crusts, and build-ups. This setting enables the mechanisms of spherulitic calcite development and the patterns of sediment accumulation to be explored in a geobiological and hydrochemical scenario similar to the 'Pre-Salt' subsurface occurrences but divorced from clay influence. The integration of logs, borehole data, outcrop photomosaics and petrographic observations collectively allowed the reconstruction of a depositional model for the East Kirkton lacustrine succession. In this model, calcite spherule nucleation took place at the sediment-water interface in the littoral zone, driven by the co-occurrence of 1) high alkalinity, 2) Ca-Mg rich hydrochemistry, and 3) microbial-derived colloidal exopolymeric substances. These environmental conditions permitted the coeval development of spherulitic cementstone build-ups and spherulitic grainstone-packstone within the wave-agitated zone, and the accumulation of floatstones and laminites of spherulitic grains in deeper lake regions by means of downslope reworking. This model is consistent with the previously documented microbial bloom occurrences and highlights the need to better understand the complex 'microbe-solution' interactions before any reliable facies model is envisaged.

Keywords: spherule, spherulitic, calcite, alkaline, lacustrine, volcanic, Carboniferous, Presalt

Running title: A depositional model for spherulitic lacustrine carbonates

\section{INTRODUCTION}

Spherulitic textures from alkaline and volcanic-influenced lacustrine environments have risen to prominence following their discovery in abundance in the Cretaceous subsurface rift lake deposits of the South Atlantic (Terra et al., 2010; Luiz-Dias, 1998; Rezende and Pope, 2015; Wright and Barnett, 2015; Saller et al., 2016). Spherules are defined as components formed 
by calcitic fibro-radial spherulitic polycrystals sensu Verrecchia et al., 1995. They are well known from a wide variety of carbonate environments including soils, lakes, hyper-saline lagoons, and marine tidal flat settings (Buczynski and Chafetz, 1993; Verrecchia et al., 1995; Braissant et al., 2003; Spadafora et al., 2010; Pueyo et al., 2011; Arp et al., 2012; Wanas 2012; Bahniuk et al., 2015). However they rarely contribute the most abundant carbonate grain in a deposit, and relevant outcrop examples of spherulitic limestone are scarce meaning that the petrography of such carbonates is poorly constrained. Discoveries of the South Atlantic 'Pre-Salt' hydrocarbon reservoirs of Brazil and Angola (Guardado et al., 2000; Moreira et al., 2007; Carminatti et al., 2008; Cazier, et al., 2014) promoted interest in deciphering the mechanisms capable of producing voluminous spherulitic carbonate deposits in volcanic and lacustrine settings (e.g., Mercedes-Martín et al., 2015; Wright and Tosca, 2016), placing the need to build facies models for these systems beyond the ability to understand their mode of formation.

Lacustrine depositional models have recently been proposed for the Aptian 'Pre-Salt' spherule-bearing succession of the Angolan margin of the Kwanza Basin (Saller et al., 2016), and the Brazilian margin of the Campos and Santos Basins (Wright and Barnett, 2015; Sabato Ceraldi and Green, 2016). These models commonly display the occurrence of spherulitic calcitic components intermingled within stevensite clays in deep lake environments. The 'shrubby' spherulitic boundstones generally occupied the shallow lake settings where coeval clay minerals were less abundant (Sabato Ceraldi and Green, 2016; Saller et al., 2016). Calcite spherule formation has previously been explained from both end-member perspectives: a biotically-influenced origin (e.g., Verrecchia et al., 1995; Arp et al., 2012), versus an abiotic mechanism (e.g., García-Ruiz, 2000; Wright and Barnett, 2015). In the case of the 'Pre-Salt' deposits, the abiotic hypothesis has been built on the assumption that the abundant smectite clays (stevensite) present in very alkaline lakes encouraged spherulitic 
calcite particle generation in association with 'clay-gel phases' (Wright and Barnett, 2015; Tosca and Wright, 2015).

To elucidate the mechanisms forming these carbonates a better understanding of the biochemistry and the source of the carbonate-precipitating waters is required. In the case of volcanic-influenced alkaline lakes, the chemical composition of these waters depends on at least three factors: 1) the balance between runoff and evaporation, commonly related to whether the basin is internally or externally draining; 2) the chemical composition of the basement and coeval extrusive rocks; and 3) the degree to which water can interact with these rocks (Bertani and Carozzi, 1985; Rowe and Brantley, 1993; Romero and Melack, 1996; Carroll and Bohacs, 1999; Bohacs et al., 2000; Narcisi, 2001; Bowser and Jones, 2002; Radke et al., 2002; Kebede et al., 2005; Ayenew, 2008; Bergner et al., 2009; GierlowskiKordesch, 2010; Pecoraino et al., 2015; Rogerson et al., 2017). A recurrent issue for these systems is how much carbonate can be deposited, given the mass flux of calcium and magnesium being supplied to surface systems (Renaut and Jones, 1997; Guido and Campbell, 2011). In addition, alkaline lakes are favourable habitats for a broad assemblage of microbial communities, including both benthic and planktonic microbes. Biological productivity in these lakes can be extremely high (Melack, 1981; Galat et al., 1990; Jones et al., 1998; Grant and Jones, 2000; Stockner et al., 2000; Kandianis et al., 2008). The organisms in the lakes may control carbonate precipitation directly (Stabel, 1986, Chafetz and Buczynski, 1992, Arp et al., 2001; Dittrich and Obst, 2004; Dupraz et al., 2009; Pedley et al., 2009), or indirectly by stimulating calcite crystal nucleation through the production and / or consumption of extracellular polymeric substances (hereafter EPS) (Trichet and Défarge, 1995; Arp et al., 1999; Dupraz et al., 2009; Decho, 2010). Several researchers have attempted to distinguish these bio-mediating processes from abiotic carbonate precipitating mechanisms (Burne and Moore, 1987; Kelts and Talbot, 1990; Kempe et al., 1991; Merz, 1992; Pedley, 1992; Jones 
and Renaut, 1995; Chafetz and Guidry, 1999; Schneider and Le Campion-Alsumard, 1999), but the division remains controversial.

The present study examines a spherule-rich carbonate deposit formed in a volcanic and claypoor lacustrine setting: the Lower Carboniferous East Kirkton Limestone in Scotland (Rolfe et al., 1993; Walkden et al., 1993). The East Kirkton Limestone displays an abundant assemblage of spherulitic calcite fabrics. Thus, a detailed petrographic study of such components and the sedimentological analysis of the spherule-bearing facies at East Kirkton can 1) help to better constrain the environmental conditions underpinning the formation and accumulation of these carbonates, and 2) provide an analogue case for other spherulitic carbonate occurrences like those in the Cretaceous 'Pre-Salt' lakes of the South Atlantic.

\section{GEOLOGICAL BACKGROUND}

Half-grabens and intervening highs in the Midland Valley of Scotland were generated during the Early Carboniferous by N-S oriented fault systems, with a right lateral strike-slip component (Rippon et al., 1996). The Carboniferous strata are divided into the Inverclyde (Tournasian) and Strathclyde (Viséan) Groups (Whyte, 1993; Read et al., 2002; FIG. 1). The Strathclyde Group comprises a varied succession of sedimentary and volcanic rocks, characterised by carbonaceous beds and coals. It is interpreted as largely fluvial and lacustrine in origin but affected by sporadic marine incursions (Browne and Monro, 1989). Basaltic volcanism (basanite type) increased during Strathclyde Group deposition (Whyte, 1993; FIG. 1) leaving the Midland Valley divided into a series of semi-enclosed continental basins. They were filled by fluvial, deltaic and lacustrine-lagoonal deposits (Fig. 1, 2A; Read et al., 2002). Sediments of the West Lothian Oil Shale Formation (Upper Viséan) were deposited in a large stratified freshwater lake complex developed under a humid tropical 
climate and collectively referred to as Lake Cadell (Greensmith, 1968) (Fig. 2B). The accumulation of planktonic and benthic microorganisms gave rise to oil-shale deposits under exorheic, meromictic, and deep (50 to 100m) conditions (Loftus and Greensmith, 1988; Parnell, 1988). The East Kirkton Limestone formed within this lake complex (FIG. 2B, C), comprising black shales, laminated limestones, tuffaceous clastic carbonates, and massive limestones all yielding spherulitic calcite textures (Rolfe et al., 1993; Walkden et al., 1993; Read et al., 2002, FIG. 2B). The East Kirkton Limestone displays well-exposed quarried faces and relatively undisturbed depositional geometries. Exquisitely preserved skeletons of amphibians, fishes, plants and ostracods have also been found at this locality (Smithson, 1989; Clarkson et al., 1993; Rolfe et al., 1993; Scott et al., 1993; Walkden et al., 1993). Palynological evidence shows that the East Kirkton lake was surrounded by an extensive woodland dominated by gymnosperms, pteridosperms and, later on, by lycopods (Rolfe et al., 1993; Scott et al., 1993).

\section{MATERIAL AND METHODS}

Fieldwork including sedimentary logging (sections EK-1 and 2) and sampling at East Kirkton Limestone Quarry was carried out in August 2014 (Fig. 2C; Fig. 3), with consent of Scottish Natural Heritage and West Lothian Council. Thirty eight thin sections were examined using Olympus BH2 and Nikon Microphot FX microscopes, and 45 polished slabs were also optically studied. Seven of these specimens came from borehole cores named BH-1, BH-2 and BH-3 stored at the British Geological Survey (BGS) at Keyworth, UK. Thin sections were imaged with a flat-bed scanner, and textures were mapped. Eight cuttings were carbon coated and imaged by Scanning Electron Microscopy (SEM) with a Zeiss EVO60 at the 
University of Hull. False colour Back-Scattered Electron images (BSE) were taken on thinsections to obtain micro-scale resolution compositional maps enabling delineation of different mineral phases (carbonate, clay, volcanic) and their features. An Oxford Instruments Pelitercooled type X-Max 80 EDX system was used to determine the abundance of specific elements through Energy Dispersive X-ray Spectroscopy (EDX) in thin-sections and cuttings. X-ray powder diffraction data were collected from ground samples mounted in stainless steel sample holders. A PANAlytical Empyrean diffractometer operating in Bragg-Brentano geometry with copper $\operatorname{K} \alpha 1(\lambda=1.54060 \AA)$ and a PIXEL detector was used for data collection. Sediment particle morphologies were described following Blott and Pye (2008). The term 'oncoid' is used sensu Flügel (2004): 'unattached, rounded, calcareous nodules exhibiting concentric layers and overlapping laminae around a core'. Photograph-based outcrop panels were annotated to recognise the architectural relationships within the sedimentary succession recorded from field $(\mathrm{EK} 1,2)$ and borehole core data $(\mathrm{BH}-1$, 2 and 3). Existing BGS borehole log annotations were also integrated to complement the absence of core record from BH-1, 2 and 3. Paleontological and sedimentological descriptions from previous works (Clarkson et al. 1993; Rolfe et al., 1993), and other log observations (illustrated in Goodacre, 1999) were also combined with the new results in this study.

\section{FACIES DESCRIPTIONS}

Six facies have been identified and characterised on the basis of lithology and/or sedimentary attributes. These facies are listed in Table 1, illustrated in Figs. 4, 5 and 6, and their outcrop architecture shown in Fig. 7: (1) Laminites, (2) Spherulitic grainstone-packstone , (3) 
Spherulitic cementstone, (4) Volcanic and intraclastic calcareous tuffs, (5) Intraclastic wackestone-floatstone, and (6) Shales.

\section{TABLE. 1 HEREABOUTS}

\subsection{Facies 1: Laminites}

Laminites are organised in 5 to $50 \mathrm{~cm}$-thick, dark brown to yellowish, tabular and laterally continuous beds. Laminites are made up of a sub-millimetre alternation of carbonate, organic and silica laminae (Fig. 3, 4; Table 1) packaged into couplets of up to $4 \mathrm{~cm}$-thick carbonaterich layers alternating with up to $3 \mathrm{~cm}$-thick organic or fine-grained silica-rich layers. Microscopic deformation of laminae couplets (convoluted) and macroscopic evidence of softsediment deformation (slumps) is common in the central region of the quarry, decreasing in abundance towards the SSE (Fig. 3A to D). Laminites yielded a diversity of fossils such as amphibians, scorpions, eurypterids, myriapods, ostracods, plant and wood remains (Wood et al., 1985; Clarkson et al. 1993; Rolfe et al. 1993; Ruta and Clack, 2006). Spherulitic components (see Section 6) were recognised within organic laminae (Fig. 4D, E), the latter pinching out towards the edges of the grains (Fig. 4E). Spherulitic grains were less commonly found in association with carbonate laminae. 'Spherulitic laminites' are laminites notably rich in spherulitic components (Fig. 4D, E). The laminite facies was recorded in boreholes BH-1 to 3 and in EK-1 and 2 (Fig. 7). This facies is equivalent to the 'Laminated limestones' of Rolfe et al. (1993).

Carbonate laminae (Fig. 4A) are made of $30 \mu \mathrm{m}$ to $1000 \mu \mathrm{m}$-thick pale to dark brown, wrinkled to flat, continuous micritic to microsparitic calcite bands. Individual sparitic calcite crystals can be up to $100 \mu \mathrm{m}$ in diameter, having rhombohedral shapes and mosaic fabrics. Remains of fish scales are present but scarce. Evidence of micro-faulting and microdisruption was also recognised in some intervals. Walkden et al. (1993) recorded average 
element concentrations of 5920 ppm for $\mathrm{Mg}, 10962$ ppm for $\mathrm{Sr}, 7585$ ppm for $\mathrm{Fe}$, and 387 ppm for Mn.

Organic-rich laminae (Fig. 4A, B, D, E) are made up of $7 \mu \mathrm{m}$ to $1500 \mu \mathrm{m}$-thick dark brown, wrinkled to undulated, continuous, particulate detritus-rich laminae. Backscatter electron imaging revealed irregular darker patches of iron oxide minerals up to $50 \mu \mathrm{m}$ in diameter, euhedral pyrite crystals 5-6 $\mu \mathrm{m}$ in diameter, and framboidal pyrite aggregates of up to $20 \mu \mathrm{m}$ diameter (Fig. 4C). Ostracod carapaces and plant remains were also recorded.

Silica laminae (Fig. 4B, D) are composed of up to $350 \mu \mathrm{m}$-thick dark brown, spatially irregular amorphous vitreous silica bands conformably interlayered with carbonate and organic laminae. Silica is glassy in cross-polarized light, and laminae show inclusions of single euhedral and patchy subhedral calcite crystals and cracks filled by calcite (Fig. 4B) (McGill, 1994).

\subsection{Facies 2: Spherulitic grainstone-packstone}

This facies consists of 5 to $80 \mathrm{~cm}$-thick, grey, spatially discontinuous layers of grainstonepackstone exhibiting poorly to moderately sorted spherulitic grains (FIG. 5A, see Section 6), ranging from fine to coarse sand size, and well-rounded to angular texture (Fig. 5B). Subangular volcanic lithoclasts averaging $2 \mathrm{~cm}$ in diameter and rare fragments of stacked fans (see Section 6) averaging $1 \mathrm{~cm}$ in diameter were also recognised. In some cases, a finer subcentimetre scale alternation of spherulitic grains (coated grains and intraclasts, see Section 6) was observed. Packstone matrix is composed of red-brown, fine-grained amorphous $\mathrm{Mg}-\mathrm{Si}$ phase rich in $\mathrm{Mg}, \mathrm{Al}$ and $\mathrm{Fe}$, as determined by X-ray diffraction and EDX spot analyses (see Facies 4). In some cases, millimetre-thick alternations of Spherulitic Crusts (see section 6) 
and $\mathrm{Mg}-\mathrm{Si}$ bands were recognised. Amorphous $\mathrm{Mg}-\mathrm{Si}$ phases are commonly replaced by ferroan blocky to granular calcite cements following vein-like structures (FIG. 5B). This facies was identified in the central part of the quarry (BH-2 and EK-1, Fig. 7) being very rare in the SE part.

\subsection{Facies 3: Spherulitic cementstone}

This facies is represented by up to 2 m-thick and $3 \mathrm{~m}$-wide, dark grey, un-fossiliferous carbonate units with distinctive dome-shaped to lenticular morphologies and limited lateral continuity towards the SSE of the quarry (FIG. 5C, D, E). According to Clarkson et al., (1993) this facies extended laterally at least $50 \mathrm{~m}$ to the west of BH-2 (Fig. 7). Two main metre-thick build-up intervals were identified in $\mathrm{BH}-2$ and EK-1, although tiny centimetre-thick layers were reported interbedded within Facies 1 (EK-1). This facies is sandwiched between Facies 1 and 4 (FIG. 5C, D), and in some outcrops it passes laterally into Facies 2 (seen in BH-2 and EK-1, Fig. 7). Spherulitic cementstone encompass a 'clotted' carbonate texture formed by calcite stacked fan fabrics (see Section 6) developing millimetre to centimetre-sized, crackle to mosaic pack-breccias filled by pale white quartz/chalcedony cements (FIG. 5F). This facies was only recorded in the NW and central part of the quarry and it is equivalent to the 'Massive limestones' of Muir and Walton (1957) and Rolfe et al. (1993).

\subsection{Facies 4: Volcanic tuffs and intraclastic calcareous tuffs}

This facies consists of $5 \mathrm{~cm}$ to $5 \mathrm{~m}$-thick, green to yellow, nodular and discontinuous beds of epiclastic tuffs interbedded throughout the entire succession, though more abundant and thicker units were identified at the top of the sequence (Fig. 7). These deposits can reach up 
to 7 m-thick in BH-1 and 3.3 m-thick in $\mathrm{BH}-2$. Volcanic tuffs display a fabric of coarsegrained lapilli clasts (up to $15 \mathrm{~mm}$ in diameter) floating in poorly sorted fine-grained vesicular or amygdaloidal ash with shards (FIG. 6A left). Lapilli clasts exhibit a porphyritic fabric of plagioclase, augite, olivine and magnetite phenocrysts (Fig. 6B). Calcite pseudomorphs after olivine are also present. EDX spot analyses of lapilli show abundance of $\mathrm{Al}$, Ti and $\mathrm{Ca}$, and minor amounts of $\mathrm{K}, \mathrm{Mg}$ and Fe (FIG. 6D). Petrographic and chemical analysis points to a basaltic to basanitic composition. Furthermore, centimetre to decimetrethick (averaging $20 \mathrm{~cm}$ in thickness), greenish to dark grey, heterogeneous layers of intraclastic calcareous tuffs were systematically recorded intercalated within Facies 1 in EK-1 and 2, and BH-1, 2 and 3 (Fig. 6A right; Fig. 7). These layers display sharp and erosive basal contacts, normal grading and load casts. Intraclastic calcareous tuffs comprise moderately sorted, poorly rounded, coarse sand to coarse pebble-sized fragments of volcanic tuffs, coarse sand-sized spherulitic grains and intraclastic carbonate laminae (Facies 1) embedded in submillimetre-thick patches of irregularly banded amorphous $\mathrm{Mg}$-Si minerals (kaoliniteserpentine group) as indicated by X-ray diffraction analyses (Fig. 6C). Fine grained intervals are normally made up of well sorted, very fine to medium sand-sized, dark black volcanic ash. Up to $6 \mathrm{~m}$-thick basaltic bodies are reported at the top of BH-1 though such rocks were not stored at Keyworth (borehole annotations are reprinted in Fig. 7). Overall, this facies is equivalent to the Geikie Tuff unit of Rolfe et al. (1993).

\subsection{Facies 5: Intraclastic wackestone-floatstone}

This facies comprises centimetre to decimetre-thick (up to $15 \mathrm{~cm}$-thick) continuous, nodular to tabular wackestone to floatstone layers (Fig. 6E, F) commonly observed in the upper parts of EK-2 and BH-3, but decreasing in abundance towards the NW of the quarry (FIG. 7). In some cases normal graded beds (wackestone grading to floatstone), and macroscopic and 
microscopic evidence of soft-sediment deformation was identified (slumps and convolute beds). Carbonate allochems comprise millimetre-sized contorted laminae intraclasts (Facies 1), peloids, fish scales, ostracod shells, and very rare spherulitic components floating in a micritic matrix. SEM BSE analyses reveal abundant euhedral pyrite framboids (up to $6 \mu \mathrm{m}$ in diameter), and kerogenous matter both within laminae intraclasts and the carbonate matrix. This facies is partially equivalent to the Little Cliff Shale of Rolfe et al. (1993).

\subsection{Facies 6: Shales}

This facies is constituted by up to $6 \mathrm{~m}$-thick, blue-grey, laterally variable, organic-rich shales (Fig. 5E). They were recognised in the upper parts of BH-1, BH-3 and EK-2, thinning laterally northwards (Fig. 7). It contains sporadic thin continuous horizons of centimetrethick ironstone bands, and a wide array of fossiliferous remains such as bivalves (Curvirimula scotica), fish scales and skeletons (actinopterygians, acanthodians, and sharks), ostracod shells (Carbonita), arthropod cuticles, spores, lycopsids (Lepidodendron), and other foliage remains (Rolfe et al., 1993; Clarkson et al., 1993). Shales alternate with Facies 5 as seen in EK-2 (Fig. 6E) though Facies 4 can also be sporadically interbedded within shales (e.g. BH-1). This facies is comparable to the 'Little Cliff Shale' described by Rolfe et al. (1993). 
surfaces and/or abrupt facies changes. Four types were recognised across the carbonate system studied (labelled A, B, C, and D).

\subsection{Type-A Cycle}

The thickness of this asymmetrical cycle varies between 1 and $3 \mathrm{~m}$. It is composed of millimetre to centimetre-thick shaly layers (Facies 6) (FIG. 7, 8), followed by up to $2.5 \mathrm{~m}$ thick spherulitic cementstone build-ups (Facies 3) which is sharply overlain by up to $1 \mathrm{~m}$ thick beds of grainstone-packstone of spherulitic grains (Facies 2). Evidence for paleosols or paleokarst horizons is lacking, despite this cycle was appearing to locally develop on top of an erosional surface (as seen in EK-1). This type of cycle can contain up to $15 \mathrm{~cm}$-thick intraclastic calcareous tuff layers (Facies 4) intercalated within Facies 2, centimetre-thick levels of grainstone-packstone of spherulitic grains (Facies 2) and rare centimetre-thick spherulitic-shaly limestone beds (Facies 6) intermingled within Facies 3. Type-A cycles were exclusively recorded in the NW part of the quarry (EK-1 and BH-2, Fig. 7).

\subsection{Type-B Cycle}

This type of cycle is constituted by up to $1.5 \mathrm{~m}$-thick strata bounded by sharp surfaces and forming asymmetrical sequences (Fig. 7,8 ). They are constituted by a lower part of up to 1.1m-thick spherulitic laminite beds (Facies 1) grading upwards towards up to $40 \mathrm{~cm}$-thick of grainstone-packstone of spherulitic grains (Facies 2). Type-B cycles were only recognised in the central part of the quarry (EK-1) (Fig. 7).

\subsection{Type-C Cycle}

These basic accretional units are made up of 1 to $3 \mathrm{~m}$-thick packages bounded by sharp flooding surfaces. This asymmetrical cycle is composed by a lower portion of up to $1 \mathrm{~m}$-thick 
(typically $<25 \mathrm{~cm}$-thick) organic-rich shales (Facies 6) commonly overlain by up to $2 \mathrm{~m}$-thick upper portion constituted by coarse-grained calcareous tuffs (Facies 4) grading to spherulitic laminites (Facies 1) (Type-C1, Fig. 7, 8). Facies 4 tend to show basal sharp erosional surfaces or undulating contacts due to plastic buckling on top of shale beds. In some cycles, laminites are notably devoid of spherulitic grains defining Type-C2 cycles. Type-C1 cycles were recognised in the NW part of the quarry (BH-2, EK-1 and BH-1) while Type-C2 were identified in the SE region (BH-3 and EK-2) (Fig. 7).

\subsection{Type-D Cycle}

These elemental cycles are constituted by up to $6 \mathrm{~m}$-thick strata bounded by sharp facies contrasts or flooding surfaces (Fig. 7, 8). They are organised by a metre-thick lower shalerich package (Facies 6) or laminites with absence of spherulitic grains (Facies 1) occasionally alternating with centimetre-thick intraclastic calcareous tuff levels (Facies 4), and an upper interval formed by an alternation of intraclastic wackestone-floatstone (Facies 5) and shales (Facies 6). Type-D cycles were preferentially recorded in the upper and SSE part of the quarry (EK-2 and BH-3) (Fig. 7).

\section{PETROGRAPHY OF SPHERULITIC COMPONENTS}

Spherulitic components are characterised by a recurrent combination of several crystal fabrics: Fibrous Calcite, Spherulitic Calcite, and Subhedral Silica (Table 2).

The Fibrous Calcite (sensu Schroeder, 1972; Longman, 1980, or Mazzullo, 1980) (FIG. 9A) consists of needle-like and radially divergent crystals with length-to-width ratio of $\sim 9.2: 1$ (>6:1 according to Folk, 1965) and typically average lengths and widths of $\sim 83 \mu \mathrm{m}$ and $\sim 9$ 
$\mu \mathrm{m}$ respectively. In some cases, pervasive corrosion obliterated the characteristic fibrous terminations (FIG. 9A).

Spherulitic Calcite (sensu Schroeder, 1972; Davies, 1977, or Verrecchia et al., 1995) is made up of dense spheroidal to botryoidal coatings constituted by elongated, rectilinear fibro-radial calcite polycrystals with their $c$ axes radiating from a previous substrate, and exhibiting sweeping extinction (FIG. 9B, C, D; 10A, C). A characteristic feature of Spherulitic Calcite crystals is their epitaxial growth on top of Fibrous Calcite, or other Spherulitic Calcite bodies (Fig. 9A, 9F). Polycrystals in Spherulitic Calcite are between $80 \mu \mathrm{m}$ to $2 \mathrm{~mm}$-length -length and up to $\sim 10 \mu \mathrm{m}$-width.

Spherulitic Calcite coatings exhibit corrosion scars characterised by dentate or irregular surfaces (FIG. 9D, E). Younger generations of these fabrics were nucleated on previous surfaces, and sometimes they grew in optical and lattice continuity with the older crystals. In so doing they left subtle concentric lines between each growth stage (FIG. 9F). Trace element analyses indicate a $\mathrm{Mg}$ ferroan composition (average $\mathrm{Mg}$ content of 14345ppm), and $\mathrm{Sr}, \mathrm{Fe}$ and Mn concentrations averaging 11500, 3400 and 390ppm respectively (Walkden et al., 1993).

Subhedral Silica is recognised as up to $40 \mu \mathrm{m}$ diameter crystals that exhibit single-crystal and undulose extinction (FIG. 9A, C; 10D up) and partially seen replacing Fibrous Calcite, and less commonly replacing Spherulitic Calcite.

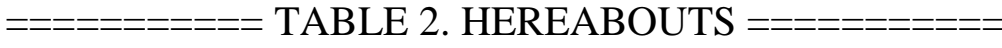

\subsection{Petrography of Spherulitic Coated Grains}

In two-dimensional sections, these grains display diverse sizes and morphologies (Table 2). Two types of particles were recognised according to their outlines. Around $85 \%$ are Type 1 
Coated Grains, described as circular to sub-circular (50 to $700 \mu$ m-diameter) with rounded to

Spherulitic Coated Grains are composed of Fibrous Calcite, and Spherulitic Calcite. Microscopy including SEM-EDX analyses revealed the absence of Mg-Si mineral inclusions within Spherulitic Calcite. Fibrous Calcite formed widespread calcite fringe coatings that nucleated on and grew normal to the core surface (FIG. 9A and 10D). Spherulitic Calcite was epitaxially nucleated upon Fibrous Calcite templates or on antecedent Spherulitic Calcite coatings. In some cases, pervasive corrosion of these crystals is later filled by Subhedral Silica. This adversely affected the continuity and terminations of fibrous crystals (FIG. 9A 
and 10D). Type 1 grains were dominated by Spherulitic Calcite adopting spheroidal coatings, whereas non-spheroidal, elongated Type 2 grains were normally made of Spherulitic Calcite displaying botryoidal fan-shaped coatings. 'Oncoidal' forms were represented by the $<5 \%$ of studied grains where concentric generations of Spherulitic Calcite grew in optical and lattice continuity around a core (FIG. 9F).

Some Spherulitic Calcite fibres experienced deflection during later stages of growth, and this is visible where crystals reached $>1 \mathrm{~mm}$ in length (FIG. 10A, B). These deviations imparted arcuate crystal terminations to the spherules. Some other grains have polished, and irregularly dentate outlines (FIG. 10C).

\subsection{Petrography of Spherulitic Crusts}

These crusts (FIG. 11; Table 2) are made up of a first generation of Fibrous Calcite fabrics nucleating from core nuclei, and a second phase constituted by Spherulitic Calcite. Spherulitic Calcite encapsulated carbonaceous filaments (mono-specific, dark brown, double walled filamentous structures and their fragments) (FIG. 11A to D). Preserved carbonaceous filaments displayed circular to prismatic outlines in transverse cross-sections $(\sim 50 \mu \mathrm{m}$ in diameter) and elongated, parallel and smooth outlines in longitudinal cross-sections (at least 4 $\mathrm{mm}$ in length). Outer boundaries of Spherulitic Calcite bundles overlap and are fused together, defining distinct planes (FIG. 11D). These planes display dissolution cavities filled by $\mathrm{Mg}$-Si minerals that in turn were replaced by younger Spherulitic Calcite (FIG. 11C, D). Spherulitic Crusts were overlain by filament-free Mg-Si-rich layers (FIG. 11A).

Circular to sub-circular abraded fragments of Spherulitic Crusts were found in Facies 1 and 4. In these cases, the tubular moulds left by the decay of the filamentous inclusions became filled by sparite (FIG. 11E, left) or amorphous Mg-Si minerals (FIG. 11E, right). Crusts were 
also seen growing around nuclei made of coated grains (FIG. 11F). Deflection of calcite fibres around algae objects was observed (Fig. 11F, inset)

\section{FIGURE. 11 HEREABOUTS}

\subsection{Petrography of Spherulitic Intraclasts}

Two types of Spherulitic Intraclasts were recognised: Type 1 (90\% in abundance), submillimetre-sized individual objects, and Type 2 (10\% in abundance), millimetre-sized tubiform objects (FIG. 12; Table 2).

Type 1 comprised elongated particles (100 to $500 \mu \mathrm{m}$ long) constituted by laterally stacked Spherulitic Calcite fans. Each intraclast measured up to 20-30 $\mu \mathrm{m}$ in width and most exhibited flat and smooth bases (Fig. 12A). Some bases had slightly irregular and corroded boundaries. Type 2 comprised individual tubiform particles reached $4 \mathrm{~mm}$ in length, and up to $2 \mathrm{~mm}$ in width, each exhibiting an outer layer of laterally and vertically-stacked Spherulitic Calcite. The latter have dimensions of 100 to $500 \mu \mathrm{m}$ in width (Fig. 12B, C). In some cases, corrosion cavities within Spherulitic Intraclasts were filled by Spherulitic Crusts (FIG. 12C, D, E). Spherulitic Calcite fans can rarely incorporate fragments of carbonaceous filaments. In such cases, calcite fibres around filaments displayed deflected growth trajectories (FIG. 12F).

\subsection{Petrography of Stacked Fans}

Carbonate 'clots' of Facies 3 (Spherulitic cementstones) are constituted by 'botryoidal-like' growths of laterally and vertically-stacked Spherulitic Calcite. Individual fans reach 100 to $1000 \mu \mathrm{m}$-thick, and 100 to $3000 \mu \mathrm{m}$ in width (FIG. 13; Table 2). Composites of laterally- 
aligned fans have lengths of several centimetres. Some Spherulitic Coated Grains served as initiation points for these fans. Scalloped solution pits and vertical cracks up to $200 \mu \mathrm{m}$ deep were observed on top surfaces (Fig. 13B, C). These corroded areas were successively epitaxially covered by lighter and turbid and pale brown Spherulitic Calcite (FIG. 13D). In some cases, chert replaced corroded fans (FIG. 13E). 10 to 50 $\mu$ m-thick continuous silica laminae separate some of the Spherulitic Calcite fans (FIG. 13C). Centimetre-sized crackle to mosaic pack-breccia interclast voids were filled with fibro-radial chalcedony cement (FIG. $13 \mathrm{~F})$.

Though Goodacre (1999) identified filamentous carbonaceous inclusions within stacked fans attributed to cyanobacterial remains, none were found in our samples, resulting in similar calcitic 'shrubby' textures to those illustrated in 'Pre-Salt' Campos Basin (Herlinger, 2016). However, intra-crystalline micro-porosity filled by kerogenous matter was observed in the calcite fans as suggested by EDX and BSE analyses (FIG. 13A).

\section{DISCUSSION}

\subsection{Geochemical considerations}

The occurrence of amorphous magnesium-silicate minerals in association with intraclastic calcareous tuffs (Facies 4) is not surprising. Alteration of Mg-rich silicates (e.g., pyroxene or olivine) from alkaline and ultramafic igneous rocks can have generated a range of $\mathrm{Mg} / \mathrm{Si}$-rich phyllosilicate phases such those recorded in East Kirkton and probably in the 'Pre-salt' lacustrine basins (Rogerson et al., 2017). According to XRD and EDX analyses such Mg-Si phases are compositionally similar to minerals of the kaolinite-serpentine group, $\left[(\mathrm{Mg}, \mathrm{Fe})_{3}\right.$ $\left.\mathrm{Si}_{2} \mathrm{O}_{5}(\mathrm{OH})_{4}\right]$. Weathering by infiltrating water may have triggered the hydrolysis of basaltic 
lavas favouring the formation of hydrous magnesium iron phyllosilicates (see Rogerson et al., 2017). A tropical and humid climate is supported by the abundant lycopod and fern vegetation surrounding the lake margins (Clarkson et al., 1993; Scott et al., 1993). Furthermore, water-rock interactions can have raised the $\mathrm{pH}$ and increased the alkalinity of the aqueous solutions sourcing the East Kirkton lake (Pecoraino et al., 2015; Deocampo and Renaut, 2016;). Enhanced susbtrate hydrolysis can release alkali cations in solution (Ca, Mg, Sr) encouraging elevated $\mathrm{CaCO}_{3}$ supersaturation in the lake waters (Rogerson et al., 2017). Moreover, the East Kirkton carbonates (laminites and spherulitic components) showed $\delta^{18} \mathrm{O}_{\text {calcite }}$ values of -11 to $-2 \%$, and $\delta^{13} \mathrm{C}_{\text {calcite }}$ values of 0 to $4 \%$ globally indicating precipitation in a meteoric-sourced, dysaerobic to anoxic, volcanic lake (Walkden et al., 1993). The lack of evaporite minerals and the depleted $\delta^{18} \mathrm{O}_{\text {calcite }}$ values questions whether the lake had persistent salinity departures.

\subsection{Diagenesis and trace element concentrations}

Subhedral Silica is usually replacing early Fibrous Calcite in those spherules encapsulating carbonaceous filaments. Filament decay may have generated favourable conduits for the circulation of silica fluids into the permeable organic cores producing enhanced silicification within and around Fibrous Calcite crystals soon after spherule formation (Fig. 14). In addition, amorphous silica lamina in laminite facies was interpreted as primary in origin via formation of silica gels because: 1) plastic deformation of slumped silica laminae show no evidence of fracturing, 2) silica laminae is cut by tiny perpendicular cracks leaving the overlying laminae unaffected (sensu McGill, 1994) (Fig. 4B).

\footnotetext{
Furthermore, the Spherulitic Calcite textures show no evidence of an original aragonite precursor neither the presence of neomorphic calcite fabrics selectively replacing aragonite.
} 
Strikingly, spherulitic fabrics contain high Mg and Sr concentrations as occur in the 'Pre-salt' shrubby carbonates where calcite was hypothesised to be directly precipitated from alkaline lake waters (Saller et al., 2016). Enhanced strontium uptake into calcite minerals originally precipitated in low-temperature alkaline experiments has been reported via initial formation of amorphous calcium carbonate (ACC) precursor phases (Littlewood, et al., 2017). The presence of dissolved $\mathrm{Mg}^{2+}$ ions can further stabilise ACC phases thus promoting $\mathrm{Sr}^{2+}$ incorporation (Rodríguez-Blanco et al., 2012) and favouring the direct transformation of ACC into calcite crystals (Loste et al., 2003; Rodríguez-Blanco et al., 2012) with highmagnesium contents (Raz et al., 2000; Wang et al., 2012). The initial formation of ACC can be achieved in moderate to high alkalinity environments with concomitant high $\mathrm{Mg}: \mathrm{Ca}$ contents (Wang et al., 2012) turning alkaline lake chemistries suitable for potential primary precipitation of high-Mg calcites.

\subsection{Sedimentology of spherulitic components}

The isopachous calcite rims of Fibrous Calcite grew upon organic cores in conditions favourable for crystal nucleation. Such conditions may have included elevated $\mathrm{pH}$ and high alkalinity linked to high $\mathrm{CaCO}_{3}$ supersaturation, perhaps coupled with active water agitation (e.g. Schroeder, 1972; Longman, 1980) and abundance of loose carbonaceous material to form cores (Fig. 14). The epitaxial growth of Spherulitic Calcite on top of Fibrous Calcite indicates that the crystalline substrate played a role in the development of these fabrics (Fig. 14). Indeed, the shape of the cores in Spherulitic Coated Grains (Type 1 and Type 2) seemingly dictated the final external morphology (FIG. 10C). Absence of evidence for clay or volcaniclastic inclusions within Spherulitic Calcite suggest that Spherulitic Coated Grains developed at the sediment-water interface rather than within the sediment. Absence of conspicuous biological inclusions further suggests that the type of microbial communities 
thriving at the time of spherule formation did not leave noticeable organic remains. Evidence of clay cavity-filling textures within spherules is here consistent with late corrosion processes. All of this evidence points to a depositional environment capable of forming packstone, grainstone and floatstone of Spherulitic Coated Grains regularly agitated by currents and supplied by plant debris (common nuclei) at or above the sediment-water interface.

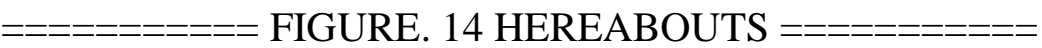

Conversely, Spherulitic Crusts tended to incorporate filamentous components into their crystal structure. Petrographic analysis suggests that Spherulitic Crusts grew within an intertwined framework of filamentous green algae (Cladophora-like) (FIG. 11C, 15). Deviation of the Spherulitic Calcite growth trajectories in proximity to algal fragments further suggests that crystallite trajectories were affected by the presence of these objects (Fig. 11F). Overlapping of crystal fans is compatible with competitive growth of Spherulitic Calcite bundles that ceased when remaining space was filled. Lack of sediment inclusions indicates that growth occurred above the sediment-water interface (Fig. 15). In the East Kirkton Lake, very rare $\mathrm{Mg}$-Si mineral occurrences were recognised and these were found overlaying spherulitic crusts (Fig. 10A). Such phyllosilicate layers were largely devoid of carbonaceous filaments, consistent with a cessation of algal production during $\mathrm{Mg}-\mathrm{Si}$ presence (Fig. 11A; 15).

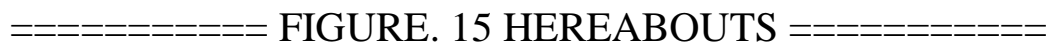

The Spherulitic Calcite forming Spherulitic Intraclasts are likely calcite encrustations on the external surfaces of subaquatic plants and algae or within internal cavities producing laterally-linked botryoids (Type 1) (FIG. 16). Similarly, tubular spherulitic aggregates may 
have originally encrusted macro-algal thallae (Type 2). Subsequent reworking of the organic templates may have generated intraclastic textures seen in thin sections (FIG. 12, 16). The predominance of packstone-grainstone textures supports the contention that water agitation was a factor in their accumulation. Similar fibro-radial crystals have been reported as forming attached to the trichomes of freshwater cyanobacterium Nostoc parmelioides (Freytet and Verrecchia, 1993), filling the axial voids of the freshwater algae Zarramenella minorica (Freytet et al., 1999), or the lysed cells of the green-alga Cladophoropsis (Arp et al., 2003).

\section{FIGURE. 16 HEREABOUTS}

Stacked Fan nucleation and growth likely required a static substrate (FIG. 17), and these facies may be partially analogous to stacked botryoidal micro-stromatolitic crusts (20 to $60 \mu \mathrm{m}$-thick) and globular aragonitic fans of Satonda Lake, Indonesia (Arp et al., 2003). The crusts of Arp et al. (2003) veneered the outer moulds of green algal filaments and were terminated by smooth, undulating surfaces. East Kirkton Stacked Fans, however, lacked noticeable organic filaments (although these are mentioned by Goodacre, 1999), which raises questions over the spatial organisation of active calcite growth and the microbes that will inevitably have been present within this site.

Petrography shows epitaxial Spherulitic Calcite nucleated on previously corroded fans (Fig. 13D), indicating that corrosion occurred during growth stages, and that sustainable conditions for Spherulitic Calcite growth re-emerged after short-lived dissolution events (FIG. 17). Lack of clay or volcaniclastic materials within Stacked Fans suggests that they may have formed in an agitated subaqueous environment. 


\subsection{Cyclostratigraphy and depositional model}

Cycle data was integrated with the sedimentological observations of spherule-bearing lithofacies (Fig. 7) and spherulitic components (Fig. 14 to 17). This allowed the reconstruction of the depositional model for the East Kirkton sedimentary succession (Fig. 18) and comparisons with the 'Pre-salt' cyclostratigraphic data.

\subsubsection{Littoral environment}

Type-A cycles characterise the shallower lake environments where carbonate production took place in moderate to high energy conditions, perhaps in the littoral to proximal sublittoral setting towards the lake centre. This environment was located on the NNW side of the quarry (Fig 7). Type-A cycles reflect an initial transgressive phase (Facies 6) overlain by a regressive spherule-dominated stage (Facies 2 and 3) (Fig 7). The sporadic occurrence of poorly sorted spherulitic grainstone to packstone on top of these cycles points to intermittent low-energy periods enabling co-occurrence with Mg-Si minerals. Spherulitic Coated Grains, Spherulitic Crusts, and Spherulitic Intraclasts were penecontemporaneously nucleated in this setting, which hosted the optimal conditions for nucleation and growth of Spherulitic Calcite (Fig. 18). Moreover, the fact that Facies 2 and 3 are laterally linked or intermingled suggest that they formed in close temporal association. The local erosional truncation underlying Type-A cycles likely reflects a phase of lake contraction followed by the development of spherulitic cementstone build-ups during a resumed lake re-flooding (Fig. 7, 8). Intermittent input of undersaturated waters into the lake (sensu Driscoll and Newton, 1985; Reuss et al., 1987) could explain some early dissolution features in spherulitic textures. McGill (1994) and Walkden et al. (1993) documented cathodoluminiscence banding in spherulitic components that would be coherent with $\mathrm{E}_{\mathrm{H}}-\mathrm{pH}$ variations of the fluids forming these grains. The shallow 


\subsubsection{Sublittoral to shallow profundal environment}

Type-B and C cycles define the littoral to sublittoral settings respectively, which were located in the central part of the quarry (Fig 7). Type-B cycles show an initial deepening phase (Facies 1), and a subsequent shallowing phase (Facies 2). More distal Type-C cycles ( $\mathrm{C} 1$ and C2) display a transgressive pulse (Facies 6), and a regressive stage formed by the stacking of Facies 1 and 4. Normal graded beds with erosive bases are best interpreted as pulses of downslope sediment gravity transport triggered by slumping processes (e.g., Lowe, 1979) generated during regressive intervals (Fig 7,8 ). The fold axes of slumps and convolute beds are similarly grouped sub-parallel to one another and parallel to the inferred paleo-slope strike suggesting that soft-sediment deformation (slumping and convolute laminae) was likely 


\subsubsection{Profundal environment}


Type-D cycles indicate sedimentation in a profundal lake setting under low energy conditions found predominantly in the SE part of the quarry (Fig. 7, 18). These cycles display an initial shale-rich deepening interval (Facies 6) followed by carbonate-rich shallowing intervals (Facies 5) (Fig 7). Graded and convolute beds are evidence for gravity flows and reworking of semi-consolidated layers from lake margins to depocentres. Preservation of pyrite framboids and fauna and flora indicates conditions of water stagnation and oxygen depletion. These features imply the bottom was well below lake wave base, which is reliable with earlier suggestions that the lake was of sufficient water depth to sustain sporadic meromictic conditions and support nektonic vertebrate life (Parnell, 1988; Loftus and Greensmith, 1988; Clarkson et al., 1993). Similar anoxic conditions were reported in the 'Pre-salt' lakes during the sag 2 microbial interval when organic-rich shales and marls were deposited in the deeper parts (Sabato Ceraldi and Green, 2016).

\subsection{Origin of Spherulitic Calcite: microbes versus stevensite}

Nucleation of Spherulitic Calcite is a phenomenon that has been linked to bacterial and cyanobacterial activity, as demonstrated through laboratory experimentation (Buczynski and Chafetz, 1993; Verrecchia et al., 1995; González-Muñoz et al., 2000; Braissant et al., 2003; Ercole et al., 2007; Rodríguez-Navarro et al., 2007; Sánchez-Navas et al., 2009; Pedley et al., 2009). Microbial physiological processes (see Arp et al., 2003; Dupraz et al., 2009; Decho 2010) can alter the subaqueous carbonate equilibrium to effectively promote calcium carbonate precipitation that in some cases exhibits spherulitic morphologies (Verrecchia et al., 1995; Rodríguez-Navarro et al., 2007; Arp et al., 2012). However, in hyper-alkaline systems these metabolic activities are less likely to stimulate substantial calcification (Arp et al., 2001; 
2012). In these settings bacterial degradation of the biofilm EPS significantly increases supersaturation and promote calcification (Arp et al., 1999; Dupraz, et al., 2009; Decho, 2010). Indeed, fibrous and radially-divergent aragonite layers are interpreted from lysed green algal structures in Satonda Lake (Arp et al., 2003). Similarly, millimetre-sized aragonite spherules grew and accumulated within deeper parts of cyanobacterial mats in the Recent Kiritimati Lake where progressive EPS degradation was attributed to spherule formation (Arp et al., 2012). In all these cases, calcite precipitation will be occurring in environments rich in dissolved EPS, which have been demonstrated to promote spherule formation (Braissant et al., 2003, Wolthers et al., 2008; Mercedes-Martín et al., 2016). This mechanism is highly likely to be responsible for the abundant spherulitic carbonates at East Kirkton, and the absence of fossilised bacteria suggesting that calcite mineralisation is forming within degrading EPS gels rather than within actively photosynthesising biofilms (sensu Trichet and Défarge, 1995; Arp et al., 2003; 2012) and in alkaline lakes (Walkden et al., 1993; Rogerson et al., 2017). Whether EPS molecules are produced from lake benthic biofilms or being sedimented as polymer gels from colloidal planktonic material onto the lake bottom (Decho, 1990; Hoagland et al., 1993; Passow et al., 2001; Passow, 2002) is unclear, but likely only relevant as an indicator of the water depth at which Spherulitic Calcite formation took place. This mechanism is supported by the abundance of bacterial and microalgal planktonic organisms known from the Midland Valley Carboniferous oil-shale lakes (Loftus and Greensmith, 1988; Parnell, 1988; Raymond, 1991).

In the 'Pre-salt' lakes, stevensite clay was invoked to participate in the growth of calcitic spherules (Tosca and Wright, 2015; Wright and Barnett, 2015). In East Kirkton, amorphous clay is limited to tiny occurrences in the sublittoral slope settings where chemical $(\mathrm{pH}$, alkalinity, saturation index) and physical (low energy) conditions enabled its formation and accumulation. At the same time, stevensite mineral formation is favoured at high $\mathrm{pH}$, high 


\subsection{Hydrological implications}

The sedimentary record of the East Kirkton lake displays two incomplete, large-scale deepening-shallowing cycles bounded by an erosional surface interpreted as an unconformity formed in the littoral lake portion (Fig. 7, 8). These larger-scale cycles may reflect a broad deepening pulse, as Type- $\mathrm{C} 2$ and $\mathrm{D}$ cycles are progressively more abundant upwards in the sedimentary sequence (Fig 7). A change towards a more humid climate is recorded by the transition from gymnosperm to lycopsid vegetation in the lake margin (Scott et al., 1993), and from tetrapods-arthropods to fishes-ostracods within the lake water (Clarkson et al., 1993), thus the overall deepening trend of the lake appears to reflect increasing water incursion. Variable water input is also reflected in the wide spectrum of $\delta^{18} \mathrm{O}_{\text {calcite }}$ reported from the 'Pre-Salt' spherulitic carbonates of Brazil (-6 to 5\%) and Angola (-2 to 3\%), which fall within a broad range between fresher and more evaporative lake water conditions (Saller et al., 2016; Sabato Ceraldi and Green, 2016). Although the unusual carbonate phases of East Kirkton and the 'Pre-Salt' are certainly dependent on sufficiently high calcite supersaturation to form, this is apparently decoupled from evaporation. The lack of sulphates, chlorides, or their calcite/silica pseudomorphs even in the most regressive facies further indicates that the lake was not truly endorheic. It therefore seems unlikely that hydrological closure was a 
pivotal precondition for the development of calcitic spherules (Saller et al., 2016; Sabato Ceraldi and Green, 2016)

\section{CONCLUSIONS}

1) A widespread assemblage of calcite spherulitic components (Coated Grains, Intraclasts, Crusts, and Stacked Fans) were formed in a clay-poor, volcanic and alkaline lacustrine system.

2) The carbonate factory of spherulitic components was located in the littoral lake region (Fig. 18). This setting experienced a combination of high alkalinity, metal-rich hydrochemistry, and microbe-derived organic acid interference with the mineral formation process. These conditions collectively encouraged widespread Spherulitic Calcite nucleation at the sedimentwater interface.

3) Spherulitic Coated Grains were nucleated at the sediment-water interface on loose organic cores in an agitated environment (Fig. 14). Initial isopachous rims of Fibrous Calcite coated these cores. Spherulitic Calcite grew epitaxially upon Fibrous Calcite giving the characteristic spheroidal shape to the grains. Spherulitic Crusts grew at the sediment-water interface within an intertwined framework of filamentous green algae subsequently buried by amorphous MgSi matrices (Fig. 15). Spherulitic Intraclasts may have first formed as Spherulitic Calcite bodies laterally encrusted to organic templates. Later reworking produced the intraclastic texture (Fig. 16). Stacked Fans grew as laterally-stacked, Spherulitic Calcite nucleated upon static substrates building metre-thick lenticular spherulitic cementstones (Fig. 17). Spherulitic nucleation resumed upon corroded surfaces indicating that conditions of calcite supersaturation alternated with periods of undersaturation. Corrosive events are linked to input of fresher waters into the lake. 


\section{ACKNOWLEDGEMENTS}

BP Exploration Co. is thanked for funding, and particularly the Carbonate Team for supporting this research and for fruitful discussions. West Lothian Council and Scottish Natural Heritage are thanked for allowing access and permission for sampling the site. Graham Tulloch (BGS Edinburgh), Nick Fraser (NMS), Tracey Gallagher and the Core Store Team at BGS Keyworth are particularly acknowledged for their assistance. Rona McGill is kindly thanked for provide the photomosaic in Figure 3. Tony Sinclair, Mark Anderson (University of Hull), and Bouk Lacet (VU University Amsterdam) are thanked for sample preparation. Reviewers are warmly thanked for their detailed and valuable comments which help to sharpen the manuscript. Peir Pufahl is acknowledged for his constructive advice on an earlier draft, and Nereo Preto for his editorial assistance.

\section{REFERENCES}


Arp, G. Reimer, A. and Reitner, J. (2001). Photosynthesis-induced biofilm calcification and calcium concentrations in Phanerozoic oceans. Science 292, 1701-1704.

Arp, G., Helms, G., Karlinska, K., Schumann, G., Reimer, A., Reitner J. and Trichet. J. (2012). Photosynthesis versus exopolymer degradation in the formation of microbialites on the atoll of Kiritimati, Republic of Kiribati, Central Pacific. Geomicrobiology Journal, 29, 29-65

Arp, G., Reimer, A. and Reitner, J. (2003). Microbialite formation in seawater of increased alkalinity, Satonda Crater Lake, Indonesia. Journal of Sedimentary Research, 73, 105-127.

Arp, G., Thiel, V., Rimer, A., Michaelis, W. and Reitner, J. (1999). Biofilm exopolymers control microbialite formation at thermal springs discharging into alkaline Pyramid Lake, Nevada, USA. Sedimentary Geology, 126, 159-176.

Ayenew, T. (2008). Major ions composition of the groundwater and surface water systems and their geological and geochemical controls in the Ethiopian volcanic terrain. Ethiopian Journal of Science, 28, 171-188

Bahniuk, A. M., Anjos, S., França, A. B., Matsuda N., Eiler, J., Mckenzie, J. A. and Vasconcelos. C. (2015). Development of microbial carbonates in the Lower Cretaceous Codó Formation (north-east Brazil): Implications for interpretation of microbialite facies associations and palaeoenvironmental conditions. Sedimentology, 62, 155-181.

Bergner, A. G. N., Strecker, M. R., Trauth, M. H., Deino, A., Gasse, F., Blisniuk, P. and Dühnforth, M. (2009). Tectonic and climatic control on evolution of rift lakes in the Central Kenya Rift, East Africa. Quaternary Science Reviews, 25-26, 2804-2816.

Bertani, R. T. and Carozzi, A. V. (1985). Lagoa Feia Formation (Lower Cretaceous) Campos Basin, offshore Brazil: Rift Valley type lacustrine carbonate reservoirs - II. Journal of Petroleum Geology, 8, 199-220. 
Blott, S. J. and Pye, K. (2008). Particle shape: a review and new methods of characterization and classification. Sedimentology, 55, 31-63.

Bohacs, K. M., Carroll, A. R., Neal, J. E. and Mankiewicz, P. J. (2000). Lake-basin type, source potential, and hydrocarbon character: an integrated sequence-stratigraphicgeochemical framwework In: Lake basins through space and time (Eds E. H. GierlowskiKordesch, and K. Kelts. AAPG Studies in Geology 46, 3-37.

Bowser, C. J. and Jones, B. F. (2002). Mineralogic controls on the composition of natural waters dominated by silicate hydrolysis. American Journal of Science, 302, 582-662.

Braissant, O., Cailleau, G., Dupraz, C. and Verrecchia, E. P. (2003). Bacterially induced mineralization of calcium carbonate in terrestrial environments: the role of exopolysaccharides and amino acids. Journal of Sedimentary Research, 73, 485-490.

Browne, M. A. E. and Monro, S. K. (1989). Evolution of the coal basins of central Scotland. XIe Congrès International de Stratigraphie et de Géologie du Carbonifère. Compte Rendu 5, 1-19.

Buczynski, C. and Chafetz, H. S. (1993). Habit of bacterially induced precipitates of calcium carbonate: examples from laboratory experiments and recent sediments. In: Carbonate Microfacies (Eds. R. Rezak, D. L. Lavoie). Frontiers in Sedimentary Geology. pp 105-116

Burne, R. V., and Moore, L. S. (1987). Microbialites: organosedimentary deposits of benthic microbial communities. Palaios, 2, 241-254.

Cameron, I. B., Aitken, A.M., Browne, M.A.E. and Stephenson, D. (1998). Geology of the Falkirk district. Memoir of the British Geological Survey, Sheet 31 E (Scotland).

Carminatti, M., Wolff, B., and Gamboa, L. (2008). New exploratory frontiers in Brazil. 19th World Petroleum Congress. World Petroleum Congress. 
Carroll, A. R. and Bohacs, K. M. (1999). Stratigraphic classification of ancient lakes: balancing tectonic and climatic controls. Geology, 27, 99-102.

Cazier, E. C., C. Bargas, L. Buambua, S. Cardosa, H. Ferreira, A. Lopez, T. Nicholson, C. Olson, A. Saller, and J. Shinol (2014). Petroleum geology of Cameia field, deepwater Pre-Salt Kwanza Basin,Angola, West Africa: AAPG Search and Discovery article 20275.

Chafetz, H. S., and Buczynski, C. (1992). Bacterially induced lithification of microbial mats. Palaios, 7 (3), 277-293.

Chafetz, H. S., and Guidry, S. A. (1999). Bacterial shrubs, crystal shrubs, and ray-crystal shrubs: bacterial vs. abiotic precipitation. Sedimentary Geology, 126(1), 57-74.

Clarkson, E. N. K., Milner, A. R., and Coates, M. I. (1993). Palaeoecology of the Viséan of East Kirkton, West Lothian, Scotland. Transactions of the Royal Society of Edinburgh: Earth Sciences, 84, 417-425.

Decho, A. W. (2010). Overview of biopolymer-induced mineralization: what goes on in biofilms?. Ecological Engineering, 36,137-144.

Deocampo, D. M., and Renaut, R. W. (2016). Geochemistry of African Soda Lakes. In: Soda Lakes of East Africa (pp. 77-93). Springer International Publishing.

Dittrich, M. and Obst, M. (2004). Are picoplankton responsible for calcite precipitation in lakes? Ambio, 33, 559-564.

Driscoll, C. T. and Newton, R. M. (1985). Chemical characteristic of Adirondack lakes: individual lakes respond differently to acid deposition. Environmental Science Technology, 19, 1018-1024.

Dupraz, C., Reid, R. P., Braissant, O., Decho, A. W., Norman, R. S., and Visscher, P. T. (2009). Processes of carbonate precipitation in modern microbial mats. Earth-Science Reviews, 96, 141-162. 
Ercole, C., Cacchio, P., Botta, A. L., Centi, V., and Lepidi, A. (2007). Bacterially induced mineralization of calcium carbonate: the role of exopolysaccharides and capsular polysaccharides. Microscopy and Microanalysis, 13, 42-50.

Flugel, E. (2004). Microfacies of carbonate rocks: analysis, interpretation and application. Springer.

Folk, R. L. (1965). Some aspects of recrystallization in ancient limestones. In: Dolomitization and limestone diagenesis (Eds. L. C. Pray). Society of Economic Paleontologists and Mineralogists, Special Publication 13, 14-48.

Freytet, P., and Verrecchia, E. (1993). Complex calcitic crystallizations in nostoc parmelioides kütz (Freshwater cyanobacterium): Rhombs around trichomes inside nostoc colonies and epiphytic bacterial microstromatolites. Geomicrobiology Journal, 11, 77-84.

Freytet, P., Toutin-Morin, N., Broutin, J., Debriette, P., Durand, M., EI Wartiti, M., and Sarfati, J. (1999). Palaeoecology of non-marine algae and stromatolites: Permian of France and adjacent countries. Annales de Paléontologie 85, 99-153.

Galat, D. L., Verdin, J. P. and Sims, L. L. (1990). Large-scale patterns of Nodularia spumigena blooms in Pyramid Lake, Nevada, determined from Landsat imagery: 19721986. Hydrobiologia, 197, 147-164.

García-Ruiz, J. M. (2000). Geochemical scenarios for the precipitation of biomimetic inorganic carbonates. In: Carbonate sedimentation and diagenesis in the evolving Precambrian world (Eds. J. Grotzinger and N. James). SEPM Special Publications, 67, 75-89.

Gierlowski-Kordesch, E. H. (2010). Lacustrine carbonates. Developments in Sedimentology, 61, 1-101. 


\section{González-Muñoz, M. T., Chekroun, K. B., Aboud, A. B., Arias, J. M., and Rodríguez-}

Gallego, M. (2000). Bacterially induced Mg-calcite formation: role of $\mathrm{Mg}^{2+}$ in development of crystal morphology. Journal of Sedimentary Research, 70, 559-564.

Goodacre, I. R. (1999). Microbial carbonates in lacustrine settings: an investigation into the Carboniferous East Kirkton Limestone. Doctoral dissertation, University of Aberdeen.

Gradstein, F. M., Ogg, J. G. and Hilgen, F. J. (2012). On the geological time scale. Newsletter Stratigraphy, 45, 171-188.

Grant, W. D. and Jones, B. E. (2000). Alkaline environments. In: Encyclopedia of Microbiology, volume 1 (Ed. J. Lederberg). Academic Press.

Greensmith, J. T. (1968). Palaeogeography and rhythmic deposition in the Scottish OilShale Group. In: United Nations Symposium on the Development and Utilization of Oil Shale Resources, Section B (pp. 1-16).

Guardado, L. R., Spadini, A. R., Brandão, J. S. L., and Mello, M. R. (2000). Petroleum System of the Campos Basin, Brazil. AAPG Memoir 73, Chapter 22.

Guido, D.M., Campbell, K.A. (2011). Jurassic hot spring deposits of the Deseado Massif (Patagonia, Argentina): Characteristics and controls on regional distribution. Journal of Volcanology and Geothermal Research 203, 35-47.

Herlinger, R. (2016). Controles deposicionais e diagenéticos das propriedades petrofísicas dos reservatórios Aptianos/Barremianos do grupo Lagoa Feia no norte da Bacia de Campos. MSc Dissertation. Universidad Federal do Rio Grande do Sul. Brazil. 124pp.

Hoagland, K. D., Rosowski, J. R., Gretz, M. R., and Roemer, S. C. (1993). Diatom extracellular polymeric substances: function, fine structure, chemistry, and physiology. Journal of Phycology, 29, 537-566.

Jones, B. E., Grant, W. D., Duckworth, W. and Owenson, G. G. (1998). Microbial diversity of soda lakes. Extremophiles, 2, 191-200. 
Jones, B., and Renaut, R. W. (1995). Noncrystallographic calcite dendrites from hot-spring deposits at Lake Bogoria, Kenya. Journal of Sedimentary Research, 65, 154-169.

Kandianis, M. T., Fouke, B. W., Johnson, R. W., Veysey II, J. and Inskeep, W. P. (2008). Microbial biomass: a catalyst for $\mathrm{CaCO}_{3}$ precipitation in advection-dominated regimes. GSA Bulletin, 120, 442-450.

Kebede, S., Travi, Y., Alemayehu, T. and Ayenew, T. (2005). Groundwater recharge, circulation and geochemical evolution in the source region of the Blue Nile River, Ethiopia. Applied Geochemistry, 20, 1658-1676.

Kelts, K., and Talbot, M. (1990). Lacustrine carbonates as geochemical archives of environmental change and biotic/abiotic interactions. In: Large Lakes (Eds. M. M. Tilzer and C. Serruya). 288-315. Springer Berlin Heidelberg.

Kempe, S., Kazmierczak, J., Landmann, G., Konuk, T., Reimer, A., and Lipp, A. (1991). Largest known microbialites discovered in Lake Van, Turkey. Nature, 349, 605-608.

Littlewood, J. L., Shaw, S., Peacock, C. L., Bots, P., Trivedi, D., \& Burke, I. T. (2017). Mechanism of Enhanced Strontium Uptake into Calcite via an Amorphous Calcium Carbonate Crystallization Pathway. Crystal Growth \& Design, 17(3), 1214-1223.

Loftus, G.W.F. and Greensmith, J. T. (1988). The lacustrine Burdiehouse Limestone Formation - a key to the deposition of the Dinantian Oil Shales of Scotland. In: Lacustrine Petroleum Source Rocks. (Eds. A. J.Fleet, K. Kelts, M. R.Talbot). Geological Society of London, Special Publications, 40, 219-234.

Longman, M. W. (1980). Carbonate diagenetic textures from nearsurface diagenetic environments. AAPG Bulletin, 64, 461-487.

Loste, E., Wilson, R. M., Seshadri, R., and Meldrum, F. C. (2003). The role of magnesium in stabilising amorphous calcium carbonate and controlling calcite morphologies. Journal of Crystal Growth, 254(1), 206-218. 
Lowe, D. R. (1979). Sediment gravity flows: their classification and some problems of application to natural flows and deposits. In: Geology of Continental Slopes (Eds. L. J. Doyle and O. H. Pilkey). SEPM Special Publications, 27, 75-82.

Luiz-Dias, J. (1998). Análise sedimentológica e estratigráfica do Andar aptiano em parte da margem leste do Brasil e no platô das Malvinas: considerações sobre as primeiras incursões e ingressões marinhas do oceano Atlântico Sul Meridional. Doctoral dissertation. Universidade Federal do Rio Grande do Sul. 1-411.

Mazzullo, S. J. (1980). Calcite pseudospar replacive of marine acicular aragonite, and implications for aragonite cement diagenesis. Journal of Sedimentary Research, 50, 409422.

McGill, R. A. R. (1994). Geochemistry and petrography of a Lower Carboniferous, lacustrine, hot spring deposit: East Kirkton, Bathgate, Scotland. Doctoral dissertation, University of Glasgow.

Melack, J. M. (1981). Photosynthetic activity of phytoplankton in tropical African soda lakes. Hydrobiologia, 81, 71-85.

Mercedes-Martín, R., Rogerson, M. R., Brasier, A. T., Vonhof, H. B., Prior, T., J., Fellows., S. M., Reijmer, J.J.G., Billing, I., and Pedley, H. M., (2016). Growing spherulitic calcite grains in saline, hyperalkaline lakes: experimental evaluation of the effects of Mg-clays and organic acids. Sedimentary Geology, 335, 93-102.

Merz, M. U. (1992). The biology of carbonate precipitation by cyanobacteria. Facies, 26, 81101.

Moreira, J. L. B., C.V. Madeira, J.A., Gil, and M.A. P.Machado (2007). Bacia de Campos (carta estratigráfica). Boletim de Geociencias da Petrobras, 14, 2, 531-549.

Muir, R. D. and Walton, E. K. (1957). The East Kirkton Limestone. Transactions of the Geological Society of Glasgow, 22, 157-168. 
Narcisi, B. (2001). Palaeoenvironmental and palaeoclimatic implications of the LateQuaternary sediment record of Vico volcanic lake (central Italy). Journal of Quaternary Science, 16 (3), 245-255.

Parnell, J. (1988). Lacustrine petroleum source rocks in the Dinantian Oil Shale Group, Scotland: a review. In: Lacustrine Petroleum Source Rocks. (Eds. A. J.Fleet, K. Kelts, M. R.Talbot). Geological Society of London, Special Publications, 40, 235-246.

Passow, U. (2002). Production of transparent exopolymer particles (TEP) by phyto-and bacterioplankton. Marine ecology-progress series, 236, 1-12.

Passow, U., Shipe, R. F., Murray, A., Pak, D. K., Brzezinski, M. A. and Alldredge, A. L. (2001). The origin of transparent exopolymer particles (TEP) and their role in the sedimentation of particulate matter. Continental Shelf Research, 21, 327-346.

Pecoraino, G., D'Alessandro and W., Salvatore, I. (2015). The other side of the coin: geochemistry of alkaline lakes in volcanic areas. In: Volcanic Lakes, Advances in Volcanology (Eds. D. Rouwet, B. Christenson, F. Tassi and J. Vandemeulebrouck) IAVCEI. 219-237. Springer.

Pedley, M. (1992). Freshwater (phytoherm) reefs: the role of biofilms and their bearing on marine reef cementation. Sedimentary Geology, 79, 255-274.

Pedley, M., Rogerson, M. and Middleton, R. (2009). Freshwater calcite precipitates from in vitro mesocosm flume experiments: a case for biomediation of tufas. Sedimentology, 56, $511-527$.

Pueyo, J. J., Saez, A., Giralt, S., Valero-Garces, B. L., Moreno, A., Bao, R., Schwalb, A., Herrera, C., Klosowska, B. and Taberner, C. (2011). Carbonate and organic matter sedimentation and isotopic signatures in Lake Chungará, Chilean Altiplano, during the last 12.3 kyr. Palaeogeography, Palaeoclimatology, Palaeoecology, 307, 339-355. 
Radke, L. C., Howard, K. W. F., and Gell, P. A. (2002). Chemical diversity in southeastern Australian saline lakes. I: geochemical causes. Marine and Freshwater Research, 53, 941-959.

Raymond, A. C. (1991). Carboniferous rocks of the Eastern and Central Midland Valley of Scotland: organic petrology, organic geochemistry and effects of igneous activity. Doctoral dissertation, University of Newcastle upon Tyne.

Raz, S., Weiner, S., \& Addadi, L. (2000). Formation of high-magnesian calcites via an amorphous precursor phase: possible biological implications. Advanced Materials, 12(1), $38-42$.

Read, W.A., Browne, M.A.E., Stephenson, D., and Upton, B.J.G. (2002). Carboniferous. In: The Geology of Scotland, 4th. (Eds. N. H. Trewin). Geological Society, London, 251300.

Renaut, R.W., Jones, B. (1997). Controls on aragonite and calcite precipitation in hot spring travertines at Chemurkeu, Lake Bogoria, Kenya. Canadian Journal of Earth Sciences, 34, 801-818.

Reuss, J. O., Cosby, B. J. and Wright, R. F. (1987). Chemical processes governing soil and water acidification. Nature, 329, 27-32

Rezende, M. F. and Pope, M. C. (2015). Importance of depositional texture in pore characterization of subsalt microbialite carbonates, offshore Brazil. In: Microbial Carbonates in Space and Time: Implications for Global Exploration and Production. (Eds. D. W. J. Bosence, K. A. Gibbons, D. P. Le Heron, W. A. Morgan, T. Pritchard, and B. A. Vining). Geological Society of London, Special Publications, 418, 193-207. 
Rippon, J., Read, W. A., and Park, R. G. (1996). The Ochil Fault and the Kincardine basin:

key structures in the tectonic evolution of the Midland Valley of Scotland. Journal of the Geological Society, 153(4), 573-587.

Rodriguez-Blanco, J. D., Shaw, S., Bots, P., Roncal-Herrero, T., and Benning, L. G. (2012). The role of $\mathrm{pH}$ and $\mathrm{Mg}$ on the stability and crystallization of amorphous calcium carbonate. Journal of Alloys and Compounds, 536, S477-S479.

Rodríguez-Navarro, C., Jiménez-Lopez, C., Rodríguez-Navarro, A., González-Muñoz, M. T., and Rodríguez-Gallego, M. (2007). Bacterially mediated mineralization of vaterite. Geochimica et Cosmochimica Acta, 71, 1197-1213.

\section{Rogerson, M., Mercedes-Martín, R., Brasier, A. T., McGill, R. A., Prior, T. J., Vonhof,} H., Fellows, S., Reijmer, J. J. G., McClymont, E., Billing, I., Matthews, A and Pedley, M. (2017). Are spherulitic lacustrine carbonates an expression of large-scale mineral carbonation? A case study from the East Kirkton Limestone, Scotland. Gondwana Research. https://doi.org/10.1016/j.gr.2017.04.007.

\section{Rolfe, W. D. I. , Durant, G. P, Baird, W. J., Chaplin, C, Paton, R. L., and Reekie, R. J.} (1993). The East Kirkton Limestone, Viséan, of West Lothian, Scotland: introduction and stratigraphy. Transactions of the Royal Society of Edinburgh: Earth Sciences, 84, 177-188.

Romero, J. R. and Melack, J. M. (1996). Sensitivity of vertical mixing in a large saline lake to variations in runoff. Limnology and Oceanography, 41, 955-965.

Rowe, G. L. and Brantley, S. L. (1993). Estimation of the dissolution rates of andesitic glass, plagioclase and pyroxene in a flank aquifer of Poas Volcano, Costa Rica. Chemical Geology, 105, 71-87.

Ruta, M. and Clack, J. A. (2006). A review of Silvanerpeton miripedes, a stem amniote from the Lower Carboniferous of East Kirkton, West Lothian, Scotland. Transactions of the Royal Society of Edinburgh: Earth Sciences, 97, 31-63. 
Sánchez-Navas, A., Martín-Algarra, A., Rivadeneyra, M. A., Melchor, S. and Martín-

Ramos, J. D. (2009). Crystal-Growth Behavior in $\mathrm{Ca}-\mathrm{Mg}$ Carbonate Bacterial

Spherulites. Crystal Growth and Design, 9, 2690-2699.

Schneider, J. and Le Campion-Alsumard, T. (1999). Construction and destruction of carbonates by marine and freshwater cyanobacteria. European Journal of Phycology, 34, 417-426.

Schroeder, J. H. (1972). Fabrics and sequences of submarine carbonate cements in Holocene Bermuda cup reefs. Geologische Rundschau, 61, 708-730.

Scott, A. C., Brown, R., Galtier, J., and Meyer-Berthaud, B. (1993). Fossil plants from the Viséan of East Kirkton, West Lothian, Scotland. Transactions of the Royal Society of Edinburgh: Earth Sciences, 84, 249-260.

Smithson, T. R. (1989). The earliest known reptile. Nature, 342, 676-678.

Spadafora, A., Peri, E., McKenzie, J. A. and Vasconcelos, C. (2010). Microbial biomineralization processes forming modern $\mathrm{Ca}: \mathrm{Mg}$ carbonate stromatolites. Sedimentology, 57, 27-40.

Stabel, H. H. (1986). Calcite precipitation in Lake Constance: chemical equilibrium, sedimentation, and nucleation by algae. Limnology and Oceanography, 31, 1081-1094.

Stockner, J., Callieri, C. and Cronberg, G. (2000). Picoplankton and other non-bloomforming cyanobacteria in lakes. In: The ecology of cyanobacteria. (Eds. B. A. Whitton and M. Potts). Kluwer Academic Publishers, 195-231

Strachan, L. J., and Alsop, G. I. (2006). Slump folds as estimators of palaeoslope: a case study from the Fisherstreet Slump of County Clare, Ireland. Basin Research, 18, 451-470.

Terra G. J. S., Terra, G.J.S., Spadini, A.R., França, A.B., Sombra, C.L., Zambonato, E.E., Juschaks, L.C.d.S., Arienti, L.M., Erthal, M.M., Blauth, M., Franco, P.P., 


\author{
Matsuda, N.S., da Silva, N.G.C., Junior, P.A.M., D’Avila, R.S.F., deSouza, R.S., \\ Tonietto, S.N., dos Anjos, S.M.C., Campinho, V.S. and Winter, W.R. (2010). \\ Classificação de rochas carbonáticas aplicável às bacias sedimentares brasileiras. Bulletin \\ Geoscience Petrobras, Rio de Janeiro, 18, 9-29.
}
Tosca, N. J. and Wright, V. P. (2015). Diagenetic pathways linked to labile Mg-clays in lacustrine carbonate reservoirs: a model for the origin of secondary porosity in the Cretaceous Pre-Salt Barra Velha Formation, offshore Brazil. In: Reservoir quality of clastic and carbonate rocks: analysis, modelling and prediction. (Eds. P. J. Armitage, A. R., Butcher, J. M. Churchill, A. E. Csoma, C. Hollis, R. H. Lander, J. E. Omma, and R. H. Worden). Geological Society, London, Special Publications, 435, SP435-1.

Trichet, J. and Défarge, C. (1995). Non-biologically supported organobiomineralization. Bulletin de l'Institut Océanographique, 14, 203-236.

Verrecchia, E. P, Freytet. P., Verrecchia, K. E. and Dumont, J-L. (1995). Spherulites in calcrete laminar crusts: biogenic $\mathrm{Ca} \mathrm{CO}_{3}$ precipitation as a major contributor to crust formation. Journal of Sedimentary Research, 65, 690-700

Walkden, G. M., Roddy Irwin, J. and Fallick, A. E. (1993). Carbonate spherules and botryoids as lake floor cements in the East Kirkton Limestone of West Lothian, Scotland. Transactions of the Royal Society of Edinburgh: Earth Sciences, 84, 213-221.

Wanas, H. A. (2012). Pseudospherulitic fibrous calcite from the Quaternary shallow lacustrine carbonates of the Farafra Oasis, Western Desert, Egypt: A primary precipitate with possible bacterial influence. Journal of African Earth Sciences, 65, 105-114.

\title{
Wang, D., Hamm, L. M., Giuffre, A. J., Echigo, T., Rimstidt, J. D., De Yoreo, J.
}

Grotzinger, J. \& Dove, P. M. (2012). Revisiting geochemical controls on patterns of carbonate deposition through the lens of multiple pathways to mineralization. Faraday Discussions, 159(1), 371-386. 
Whyte, M. A. (1993). Scottish Carboniferous fresh-water limestones in their regional setting. Transactions of the Royal Society of Edinburgh: Earth Sciences, 84(3-4), 239-248.

Wolthers, M., Nehrke, G., and Fokkema, M. (2008). Coupled Effects of Aspartic Acid and Magnesium on Biocalcification. Geophysical Research Abstracts, 10, EGU General Assembly.

Wood, S. P., Panchen, A. L. and Smithson, T. R. (1985). A terrestrial fauna from the Scottish Lower Carboniferous. Nature 314, 355-356

Woodcock, N. H. (1979). The use of slump structures as palaeoslope orientation estimators. Sedimentology, 26, 83-99.

Wright, V. P., and Barnett, A. J. (2015). An abiotic model for the development of textures in some South Atlantic early Cretaceous lacustrine carbonates. In: Microbial Carbonates in Space and Time: Implications for Global Exploration and Production. (Eds. D. W. J. Bosence, K. A, Gibbons, D. P. le Heron, W.A. Morgan, T. Pritchard and B. A. Vining). Geological Society, London, Special Publications 418, 209-219.

\section{FIGURE CAPTIONS}

FIGURE 1. Litho- and chronostratigraphical divisions of the Carboniferous in the Midland Valley of Scotland. The East Kirkton Limestone area is located in the red square. Modified from Read et al., (2002). Ages from Gradstein et al., (2012).

FIGURE 2. A) The Midland Valley isopachs during Strathclyde Group deposition (modified from Read et al., 2002). B) Paleogeographic map of the Lake Cadell in the West Lothian Oil Shale Formation. Extensive volcanic piles divided the Midland Valley into a series of semi-enclosed lacustrine-lagoonal basins (modified from Parnell, 1988). Marine incursions were intermittent. C) Geological map of the East Kirkton Limestone area, modified from Cameron et al., (1998). 
FIGURE 3. The East Kirkton Limestone Quarry area. A) Photomosaic of the studied quarry and location of boreholes BH-1, BH-2 and BH-3, and logs EK-1 and EK-2 (inset) (reprinted from McGill, 1994). B) Metric-scale slumped beds inclined towards the WNW. C) Detail of B showing distorted slumped laminites. D) Internal soft-sediment deformation within a flat-bounded bed.

FIGURE 4. Laminites. A) Left: Flat tabular beds in outcrop. Right: Internal structure shows thicker yellowish carbonate laminae $[\mathrm{C}]$ alternating with thinner darker organic laminae $[\mathrm{O}]$ or silica laminae [Si] in X-Nichols. B) Composite image of alternating organic laminae [O] with primary silica laminae [Si] seen vitreous in X-Nichols (left) and milky in plane light (right). Cracks in silica laminae are filled by calcite (arrow). C) BSE image of pyrite framboids (EDX pattern, inset). D) Spherulitic laminites with Spherulitic Coated Grains [SG] displaying loosely packed textures within organic laminae. E) Organic laminae pinches out towards the edges of grains [arrows] displaying thickness variations across them. (X-Nichols image).

FIGURE 5. Spherulitic grainstone-packstone and Spherulitic cementstone. A) Laminated grainstonepackstone with spherulitic grains alternating with thin amorphous $\mathrm{Mg}-\mathrm{Si}$ clays [arrow]. B) Moderately-sorted and well-rounded grainstone-packstone of spherulitic grains in an amorphous MgSi matrix [arrow] locally replaced by blocky calcite, in X-Nichols. C) Dome-shaped spherulitic cementstone build-ups (F3) tilted on top of slumped layers made of laminites (F1), volcanic tuffs (F4) and shales (F6). Original depositional beds are inclined towards the left over the margin. D) An incised surface [dotted line] on top of laminites (F1) is filled by volcanic and intraclastic tuffs (F4), and overlaid by spherulitic cementstone (F3). E) Detail on C showing laminites (F1) overlaid by tiny shrubby 'clotted' fabrics [arrow] vertically evolving to spherulitic cementstone build-ups (F3). F) Polished slab of the spherulitic cementstone displaying clast-supported breccias filled with silica cements [red arrow]. 
FIGURE 6. Volcanic and intraclastic calcareous tuffs, Intraclastic wackestone-floatstone and Shales.

A) Volcanic tuffs in core (BH-2) and intraclastic calcareous tuffs arrowed in BH-3. B) Volcanic tuff show porphyritic texture of phenocrysts floating in a cryptocrystalline glassy matrix. Plagioclase (Pg), Clinopyroxene (Cpx) and Olivine (Ol). C) Floatstone of Spherulitic Coated Grains (SG) in a red MgSi clay matrix [S]. Lapilli intraclasts [Lap] show vesicular textures. Clay XRD pattern at the bottom (red spot). D) BSE image of a floatstone with Spherulitic Coated Grains [SG], and lapilli fragments [Lap] in a Mg-Si matrix [S]. EDX analyses of amorphous Mg-Si phases (red spots) and volcanic minerals (blue spots). E) Intraclastic wackestone-floatstone alternating with Shales (left). Cores on the right showing laminites (F1) on top of shales (F6) and volcanic tuffs (F4) (arrow to base). F) Detail of E showing Intraclastic wackestone-floatstone of contorted carbonate laminae in a muddy matrix.

FIGURE 7. A) Depositional architecture of a SSE-NNW transect in the East Kirkton Limestone Quarry including logs (EK-1 and 2) and boreholes (BH-1, 2 and 3). Two large-scale cycles are identified composed up to 5 small-scale cycles. Metre-thick basalt layers occur on top of borehole BH-1. B) Location of logs and boreholes. Stereographic projection displaying slump fold polar axes grouped fairly parallel to the inferred paleo-slope strike polar projection [blue asterisk].

FIGURE 8. Key symbols used in figures. Type section at East Kirkton succession (EK-1 and EK-2) integrating facies, small-scale cycles (SSC), large-scale cycles (LSC), sedimentary environment, lake level variations and distribution of spherulitic components.

FIGURE 9. Spherulitic Coated Grains. A) Fibrous Calcite crystals [f] are fanning out from the carbonaceous cores [c]. Pervasive corrosion and later Subhedral Silica [Ss] obliterated the fibrous terminations. B) Spherulitic Calcite fabric is made of fibro-radial polycrystals growing upon Fibrous Calcite, and producing spheroidal grains (Type 1) (X-Nichols). C) Spherulitic Calcite growing on top of elongated substrates produced botryoidal fan-shaped coatings (Type 2 grains) in X-Nichols. Subhedral Silica [Ss] cementing decayed organic filaments as seen in a BSE image.. D) Spherulitic Calcite fans show corrosion scars (dotted lines) which act as nucleation surfaces from successive 
crystals (X-Nichols). E) Detail of D showing resumed Spherulitic growth upon dissolution surfaces (dotted lines). Calcite growth directions shown in arrows (X-Nichols). F) Spherulitic 'oncoids' are formed by concentric layers of crystals growing in optical and lattice continuity upon subtle previous surfaces (yellow arrows) (X-Nichols). Deflection of fibres in the edges (red arrow) and corrosion surfaces (dotted line) are common.

FIGURE 10. Spherulitic Coated Grains. A) Spherulitic Calcite crystals commonly deflect in later stages of growth [red arrows] (X-Nichols). B) Detail of A showing crystal deflection of spherules [red arrow], and corrosion surfaces [yellow dotted line] overlaid by Spherulitic overgrowths (X-Nichols). C) Circular particles (Type 1) display Spherulitic Calcite fabrics growing in a spheroidal fashion, whereas elongated particles (Type 2) show botryoidal fan overgrowths. Note the carbonaceous core within the elongated coated grain (X-Nichols). D) Elongated algae fragments (top) or ash remains (bottom) as precursor nuclei. Fibrous Calcite fringes (f) and Subhedral Silica (Ss) are seen in cores (X-Nichols).

FIGURE 11. Spherulitic Crusts. A) Spherulitic Crusts [SC] are buried by Mg-Si layers [S]. Note sweeping extinction. X-Nichols image. B) Algae filaments with circular outlines (transversal) and elongated and smooth outlines (longitudinal)are trapped in Spherulitic Calcite. C) Boundaries between discrete Spherulitic Calcite bundles are corroded and filled by Mg-Si minerals [arrows]. D) $\mathrm{X}$-Nichols image of $\mathrm{C}$ with overlapping of crusts with sweeping extinction. Mg-Si minerals are replaced by newer epitaxially grown spherulitic crusts. E) Moulds of decayed filaments are filled by sparite (left) or Mg-Si minerals [S, arrow]. F) Spherulitic Crust fanning out from a Coated Grain. Crystal fibres deflect around algae inclusions (bottom left, arrow).

FIGURE 12. Spherulitic Intraclasts. A) Packstone of Type 1 Intraclasts formed by elongated Spherulitic Calcite objects cemented by blocky calcite (c). X-Nichols image. B) Tubiform Type 2 Intraclasts made of laterally linked Spherulitic Calcite. Tubes are filled by peloids (Pel) and buried by Mg-Si clays (S) replaced by calcite after dissolution (top). C) Panoramic view of a tubiform Type 2 
Intraclast (outlined in dotted line) filled with Spherulitic Crusts [SC]. D) Spherulitic Intraclast corroded and filled with a Spherulitic Crust [SC]. E) X-Nichols image of D. F) Spherulitic Calcite encapsulating filamentous algae. Deflection of calcite fibres is observed on top of the filament.

FIGURE 13. Stacked Fans. A) Laterally and vertically-stacked 'clotted' forms. Dark patches are kerogen. Breccias filled with silica cements [arrows]. B) Scalloped dissolution pits on top of the Stacked Fans [arrows]. C) X-Nichols image of B. Note sweeping extinction and thin and continuous silica rims outlining previous Stacked Fans [arrows]. D) Corroded Stacked Fans are successively filled by turbid, pale brown Spherulitic Calcite growing in optical and lattice continuity [arrows]. E) Chert filling corrosion cavities of fans. X-Nichols image. F) Detail in A. Interclast breccia voids (top) are filled with microcrystalline to fibro-radial/spherulitic chalcedony. Spherulitic Calcite fans (bottom) are stacked forming positive micro-reliefs. X-Nichols image.

FIGURE 14. Formation of Spherulitic Coated Grains (top to bottom).

FIGURE 15. Formation of Spherulitic Crusts (top to bottom).

FIGURE 16. Formation of Spherulitic Intraclasts (top to bottom).

FIGURE 17. Formation of Stacked Fans (top to bottom).

FIGURE 18. Depositional model of the East Kirkton Limestone deposit, including sedimentary features and the occurrence of processes, textures and small-scale cycles. Not to scale (See Fig. 8 for symbols).

TABLE 1. Summary of the facies types.

TABLE 2. Summary of the petrographic features of spherulitic components. 


\section{1}

2

3

4 Ramon Mercedes-Martín ${ }^{1 *}$, Alexander T. Brasier ${ }^{2}$, Mike Rogerson ${ }^{1}$, John J.G. Reijmer ${ }^{3,4}$, Hubert

\section{A depositional model for spherulitic carbonates associated with}

\section{alkaline, volcanic lakes}

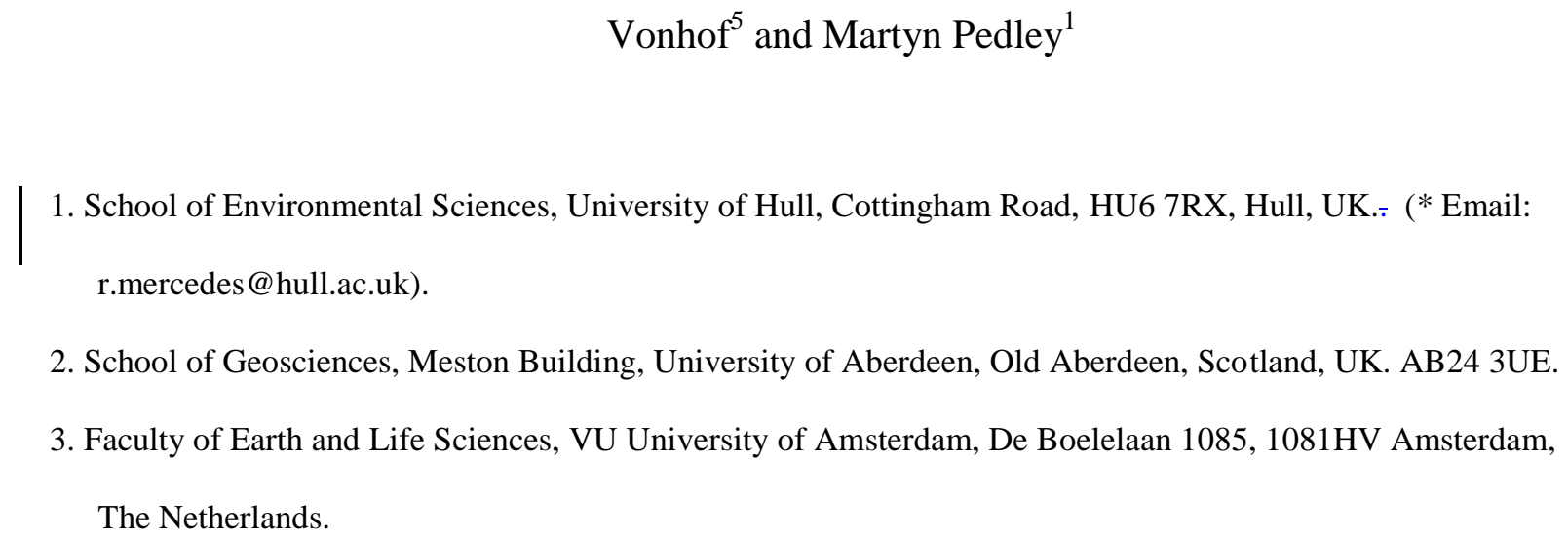

2. School of Geosciences, Meston Building, University of Aberdeen, Old Aberdeen, Scotland, UK. AB24 3UE.

3. Faculty of Earth and Life Sciences, VU University of Amsterdam, De Boelelaan 1085, 1081HV Amsterdam, The Netherlands.

4.Present at: College of Petroleum Engineering and Geosciences, King Fahd University of Petroleum and Minerals, Dhahran 31261, Saudi-Arabia

5. Max Planck Institut für Chemie, Hahn-Meitnerweg 1, 55128 Mainz, Germany.

\section{ABSTRACT}

The South Atlantic Aptian 'Pre-salt' reservoirs are formed by a combination of spherulitic carbonates and Mg-rich clays accumulated in volcanic alkaline lake settings with exotic chemistries. So far, outcrop analogues characterised by metre-thick successions deposited in lacustrine scenarios are elusive so disentangling the genesis of spherulitic carbonates represents a major scientific challenge with business impact. Althenghe Creacems spherulitic lacustrine carbonates of the 'Pre-Salt' South Atlantic rift basins host remarkable hydrocarbon reserves, the controls on spatial distributions of spherulitic facies remain poorly constrained and hotly debated. In particular the controls on spatial distribution and the environment of spherulitic facies formation remain poorly constrained, little studied, and hotly debated. Although carbonate spherulites form in a wide range of environments, the 
processes by which metre thick accumulations develop are little studied. Further complexity is added in the 'Pre-Salt' as the unusual carbonate fabrics occur in association with hydrated magnesium clays (stevensite), because interactions between clays and carbonates are pøorly understeød.To shed light on this conundrum, a spherulitic carbonate-rich, alkaline-and volcanic riftlacustrine succession has been analysed at outcrop scale: the Carboniferous East Kirkton Limestone (Scotland). Despite clays being very scarce and limited to layers of amorphous Mg-Si phasesminerals, a diverse array of earbonate-spherulitic calcitic components were formed, including coated grains, crusts, and build-ups-with spherulitic ealcitic morphologies. This setting enables the mechanisms of spherulitic fabric-calcite development and the patterns of sediment accumulation to be explored in a geobiological and hydrochemical scenario similar to the 'Pre-Salt' subsurface occurrences; but divorced from clay influence. The integration of new logs, borehole data, outcrop photomosaics and petrographic observations collectively allowed the reconstruction of a new-depositional model for the East Kirkton lacustrine succession. In this model, calcite spheruleite nucleation took place at the sediment-water interface in the littoral zone, stimulated-driven by the cooccurrence of 1) high alkalinity, 2) metalCa-Mg_rich hydrochemistry, and 3) microbialderived colloidal exopolymeric substances. These environmental conditions permitted the coeval development of shrubby spherulitic cementstoneearbonate build-ups and spherulitice grainstone-packstone within the wave-agitated zone, and the accumulation of floatstones and laminites of spherulitic grains in deeper lake regions by means of downslope reworking. This biogeochemical-model is consistent with the previously documented bacterial algalmicrobial bloom occurrences and highlights the need to better understand the complex 'microbesolution' interactions before any reliable facies model is envisaged. 
Keywords: spherulite, botryoidalspherulitic, calcite shrubby calcite, alkaline, lacustrine, volcanic, Carboniferous, Pre-salt

Running title: A depositional model for spherulitic lacustrine carbonates

\section{INTRODUCTION}

Spherulitic textures from alkaline and volcanic-influenced lacustrine environments have risen to prominence following their discovery in abundance in the Cretaceous subsurface rift lake deposits of the South Atlantic (Terra et al., 2010; Luiz--Dias, 1998; Rezende and Pope, 2015; Wright and Barnett, 2015; Saller et al., 2016). Spherulesites are defined as components formed by calcitic fibro-radial spherulitic polycrystals sensu Verrecchia et al., 1995. They are well known from a wide variety of carbonate environments including soils, lakes, hypersaline lagoons, and marine tidal flat settings (Buczynski and Chafetz, 1993; Verrecchia et al., 1995; Braissant et al., 2003; Spadafora et al., 2010; Pueyo et al., 2011; Arp et al., 2012; Wanas 2012; Bahniuk et al., 2015). However they rarely contribute the most abundant allochem carbonate grain in a deposit, and relevant outcrop examples of spherulitic limestone are scarce meaning that the petrography of such carbonates is poorly constrained. Discoveries of the South Atlantic 'Pre-Salt' hydrocarbon reservoirs of Brazil and Angola (Guardado et al., 2000; Moreira et al., 2007; Carminatti et al., 2008; Cazier, et al., 2014) promoted interest in deciphering the mechanisms capable of producing voluminous spherulitic carbonate sediments-deposits in volcanic and lacustrine settings (e.g., Mercedes-Martín et al., 2015; Wright and Tosca, 2016), placing the need to build facies models for these systems beyond the ability to understand their mode of formation.

Lacustrine depositional models have recently been proposed for the Aptian 'Pre-Salt' spherulite-bearing succession of the Angolan margin of the Kwanza Basin (Saller et al., 2016), and the Brazilian margin of the Campos and Santos Basins (Wright and Barnett, 2015; 
Sabato Ceraldi and Green, 2016). These models commonly display the occurrence of

spherulitic calcitic components intermingled within stevensite clays in deeper lake environments. The 'shrubby' spherulitic boundstones generally occupied the shallower lake settings where coeval clay minerals were less abundant (Sabato Ceraldi and Green, 2016; Saller et al., 2016).

Calcite spheruleite formation has previously been explained from both end-member perspectives: a biotically-influenced origin (e.g., Verrecchia et al., 1995; Arp et al., 2012), versus an abiotic mechanism (e.g., García-Ruiz, 2000; Wright and Barnett, 2015). In the case of the 'Pre-Salt' deposits, the abiotic hypothesis has been built on the assumption that the abundant smectite clays (stevensite) present in very alkaline lakes encouraged spherulitic calcite particle generation in association with 'clay-gel phases' (Wright and Barnett, 2015; Tosca and Wright, 2015).

To elucidate the mechanisms forming these carbonates a better understanding of the biochemistry and the source of the carbonate-precipitating waters is required. In the case of volcanic-influenced alkaline lakes, the chemical composition of these waters depends on at least three factors: 1) the balance between runoff and evaporation, commonly related to whether the basin is internally or externally draining; 2 ) the chemical composition of the basement and recentcoeval extrusive rocks; and 3) the degree to which water can interact with these rocks (Bertani and Carozzi, 1985; Rowe and Brantley, 1993; Romero and Melack, 1996; Carroll and Bohacs, 1999; Bohacs et al., 2000; Narcisi, 2001; Bowser and Jones, 2002; Radke et al., 2002; Kebede et al., 2005; Ayenew, 2008; Bergner et al., 2009; GierlowskiKordesch, 2010; Pecoraino et al., 2015; Rogerson et al., 2017). A recurrent issue for these systems is how much carbonate can be deposited, given the mass flux of calcium and magnesium being supplied to surface systems (Renaut and Jones, 1997; Guido and Campbell, 2011). In addition, alkaline lakes are favourable habitats for a broad assemblage of bacterial 
and algalmicrobial communities, including both benthic and planktonic microbes. Biological productivity in these lakes can be extremely high (Melack, 1981; Galat et al., 1990; Jones et al., 1998; Grant and Jones, 2000; Stockner et al., 2000; Kandianis et al., 2008). The organisms in the lakes may control carbonate precipitation directly (Stabel, 1986, Chafetz and Buczynski, 1992, Arp et al., 2001; Dittrich and Obst, 2004; Dupraz et al., 2009; Pedley et al., 2009), or indirectly by stimulating calcite crystal nucleation through the production and / or consumption of extracellular polymeric substances (hereafter EPS) (Trichet and Défarge, 1995; Arp et al., 1999; Dupraz et al., 2009; Decho, 2010). Several researchers have attempted to distinguish these bio-mediating processes from abiotic carbonate precipitating mechanisms (Burne and Moore, 1987; Kelts and Talbot, 1990; Kempe et al., 1991; Merz, 1992; Pedley, 1992; Jones and Renaut, 1995; Chafetz_and Guidry, 1999; Schneider and Le CampionAlsumard, 1999), but the division remains controversial.

The present study examines a spheruleite-rich carbonate deposit formed in a volcanic and eomparatively-clay-poor lacustrine setting: the Lower Carboniferous East Kirkton Limestone in Scotland (Rolfe et al., 1993; Walkden et al., 1993). The East Kirkton Limestone displays an abundant assemblage of spherulitic calcite fabrics. Thus, a detailed petrographic study of such components and the sedimentological analysis of the spherulite-bearing facies at East Kirkton can 1) help to better constrain the environmental conditions underpinning the formation and accumulation of these carbonates, and 2) provide an analogue case for other spherulitic carbonatee occurrences like those in the Cretaceous 'Pre-Salt' lakes of the South Atlantic.

\section{GEOLOGICAL BACKGROUND}


Half-grabens and intervening highs in the Midland Valley of Scotland were generated during the Early Carboniferous by N-S oriented fault systems, with a right lateral strike-slip component (Rippon et al., 1996). The Carboniferous strata are divided into the Inverclyde (Tournasian) and Strathclyde (Viséan) Groups (Whyte, 1993; Read et al., 2002; FIG. 1). The Strathclyde Group comprises a varied succession of sedimentary and volcanic rocks, characterised by carbonaceous beds and coals. It is interpreted as largely fluvial and lacustrine in origin but affected by sporadic marine incursions (Browne and Monro, 1989). Basaltic volcanism (basanite type) increased during Strathclyde Group deposition (Whyte, 1993; FIG. 1) leaving the Midland Valley divided into a series of semi-enclosed continental basins. They were filled by fluvial, deltaic and lacustrine-lagoonal deposits (Fig. 1, 2A; Read et al., 2002). Sediments of the West Lothian Oil Shale Formation (Upper Viséan) were deposited in a large stratified freshwater lake complex developed under a humid tropical climate and collectively referred to as Lake Cadell (Greensmith, 1968) (Fig. 2B). The

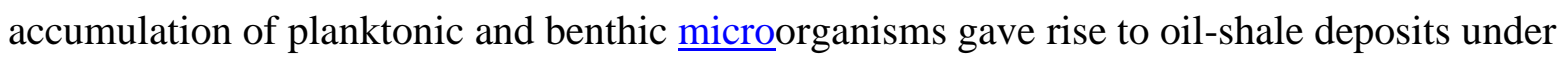
exorheic, meromictic, and deep (50 to 100m) conditions (Loftus and Greensmith, 1988;

Parnell, 1988). The East Kirkton Limestone formed within this lake complex (FIG. 2B, C), comprising black shales, laminated limestones, tuffaceous clastic carbonates, and massive limestones all yielding spherulitic calcite textures (Rolfe et al., 1993; Walkden et al., 1993; Read et al., 2002, FIG. 2B). The East Kirkton Limestone displays well-exposed quarried faces and relatively undisturbed depositional geometries. Exquisitely preserved skeletons of amphibians, fishes, plants and ostracods have also been found at this locality (Smithson, 1989; Clarkson et al., 1993; Rolfe et al., 1993; Scott et al., 1993; Walkden et al., 1993).

Palynological evidence shows that the East Kirkton lake was surrounded by an extensive woodland dominated by gymnosperms, pteridosperms and, later on, by lycopods (Rolfe et al., 1993; Scott et al., 1993). 


\section{MATERIAL AND METHODS}

Fieldwork including new-sedimentary logging (sections EK-1 and 2) and sampling at East Kirkton Limestone Quarry was carried out in August 2014 (Fig. 2C; Fig. 3), with consent of Scottish Natural Heritage and West Lothian Council. Thirty eight thin sections were examined using Olympus BH2 and Nikon Microphot FX microscopes, and 45 polished slabs

were also optically studied. Seven of these specimens came from borehole cores s-named BH-1, BH-2 and BH-3 stored at the British Geological Survey (BGS) at Keyworth, UK. Thin sections were imaged with a flat-bed scanner, and textures were mapped. Eight cuttings were carbon coated and imaged by Scanning Electron Microscopy (SEM) with a Zeiss EVO60 at the University of Hull. False colour Back-Scattered Electron images (BSE) were taken on thin-sections to obtain micro-scale resolution compositional maps enabling delineation of different mineral phases (carbonate, clay, volcanic) and their featureselements (carbonate, elay, voleanic). An Oxford Instruments Peliter-cooled type X-Max 80 EDX system was used to determine the abundance of specific elements through Energy Dispersive X-ray Spectroscopy (EDX) in thin-sections and cuttings. X-ray powder diffraction data were collected from ground samples mounted in stainless steel sample holders. A PANAlytical Empyrean diffractometer operating in Bragg-Brentano geometry with copper $\operatorname{Ka} 1(\lambda=$ $1.54060 \AA$ ) and a PIXEL detector was used for data collection. Sediment particle morphologies were described following Blott and Kenneth-Pye (2008). The term 'oncoid' is used sensu Flügel (2004): 'unattached, rounded, calcareous nodules exhibiting concentric layers and overlapping laminae around a core'. 
174
181

182

183

184

185

186

Photograph-based outcrop panels were annotated to recognise the architectural relationships

within the sedimentary succession recorded from field $(\mathrm{EK} 1,2)$ and borehole core data $(\mathrm{BH}-1$,

2 and 3). Existing BGS borehole log annotations were also integrated to complement the

absence of core record from BH-1, 2 and 3. Paleontological and sedimentological

descriptions from previous works (Clarkson et al. 1993; Rolfe et al., 1993), and other log observations (illustrated in Goodacre, 1999) are-were also combined with the new results in this manuscriptstudy.

\section{FIGURE. 3 HEREABOUTS}

\section{FACIES DESCRIPTIONS}

Six facies have been identified and characterised on the basis of lithology and/or sedimentary attributes. These facies are listed in Table 1, illustrated in Figs. 4, 5 and 6, and their outcrop architecture shown in Fig. 7: (1) Laminites, (2) Spherulitic gGrainstone-packstone of spherulitic grains, intraclasts and crusts, (3) Shrubby-Spherulitic cementstone earbonate build-ups, (4) Volcanic and intraclastic calcareous tuffs, (5) Layered carbonates Intraclastic wackestone-floatstone, and (6) Shales.

\section{TABLE. 1 HEREABOUTS}

\subsection{Facies 1: Laminites}

Laminites are organised in 5 to $50 \mathrm{~cm}$-thick, dark brown to yellowish, tabular and laterally continuous beds. Macroscopic evidence of soft-sediment deformation (slumps) is present in the central portion of the quarry (Fig. 3B, C, D). Laminites yielded a diversity of fossits such as amphibians, scorpions, eurypterids, myriapods, ostracods, plant and wood remains (Woød et al., 1985; Clarkson et al. 1993; Rolfe et al. 1993; Ruta and Clack, 2006). Laminites are in 
turn made up of a sub-millimetre alternation of carbonate, organic and silica laminae (Fig. 3, 4; Table 1) packaged into couplets of up to $4 \mathrm{~cm}$-thick carbonate-rich layers alternating with up to $3 \mathrm{~cm}$-thick organic or fine-grained silica-rich layers. Microscopic deformation of laminae couplets (convoluted) and macroscopic evidence of soft-sediment deformation (slumps) is common in the central region of the quarry, decreasing in abundance towards the SSE (Fig. 3A to D). Laminites yielded a diversity of fossils such as amphibians, scorpions, eurypterids, myriapods, ostracods, plant and wood remains (Wood et al., 1985; Clarkson et al. 1993; Rolfe et al. 1993; Ruta and Clack, 2006). Spherulitic components (see Section 6) were recognised within organic laminae (Fig. 4D, E), the latter pinching out towards the edges of the grains (Fig. 4E). Spherulitic grains were less commonly found in association with carbonate laminae. 'Spherulitic laminites' are laminites notably rich in spherulitic components (Fig. 4D, E). The laminite facies was recorded in boreholes BH-1 to 3 and in EK-1 and 2 (Fig. 7). This facies is equivalent to the 'Laminated limestones' of Rolfe et al. (1993).

Carbonate laminae (Fig. 4A,B) are made of $30 \mu \mathrm{m}$ to $1000 \mu \mathrm{m}$-thick pale to dark brown, wrinkled to flat, continuous micritic to micro-sparitic calcite bands. Individual sparitic calcite crystals can be up to $100 \mu \mathrm{m}$ in diameter, having rhombohedral shapes and mosaic fabrics.

Remains of fish scales are present but scarce. Evidence of micro-faulting and microdisruption was also recognised in some intervals. Walkden et al. (1993) recorded average element concentrations of 5920 ppm for $\mathrm{Mg}, 10962 \mathrm{ppm}$ for Sr, $7585 \mathrm{ppm}$ for Fe, and 387 ppm for Mn.

Organic-rich laminae (Fig. 4. $\underline{\mathrm{A}}, \mathrm{B}, \mathrm{D}, \mathrm{E}$ ) are made up of $7 \mu \mathrm{m}$ to $1500 \mu \mathrm{m}$-thick dark brown, wrinkled to undulated, continuous, particulate detritus-rich laminae. Backscatter electron imaging revealed irregular darker patches of iron oxide minerals up to $50 \_\mu \mathrm{m}$ in diameter, 
euhedral pyrite crystals 5-6 $\mu \mathrm{m}$ in diameter, and framboidal pyrite aggregates of up to $20 \mu \mathrm{m}$ diameter (Fig. 4C). Ostracod carapaces and plant remains were also recorded.

Silica laminae (Fig. 4B, D) are composed of up to $350 \mu \mathrm{m}$-thick eloudy dark brown, spatially irregular erystalline-amorphous vitreous silica bands conformably interlayered with carbonate and organic laminae. Silica is isotropic glassy in cross-polarized light, and laminae show inclusions of single euhedral and patchy subhedral calcite crystals and cracks filled by calcite (Fig. 4B) (McGill, 1994).

\subsection{Facies 2: Spherulitic gGrainstone-packstone of spherulitic grains, intraclasts and erusts}

This facies consists of 5 to $80 \mathrm{~cm}$-thick, grey, spatially discontinuous layers of grainstonepackstone exhibiting poorly to moderately well-sorted spherulitic grains (FIG. 5A, see Section 6), ranging from fine to coarse sand size, and well-rounded to angular texture (Fig. 5B). Sub-angular volcanic lithointraclasts averaging $2 \mathrm{~cm}$ in diameter and rare fragments of stacked fans (see Section 6) averaging $1 \mathrm{~cm}$ in diameter were also recognised. In some cases, a finer sub-centimetre scale alternation of spherulitic grains (coated grains and intraclasts, see Section 6) was observed. Packstone matrix is composed of red-brown, fine-grained amorphous $\mathrm{Mg}$-Si phase rich in $\mathrm{Mg}, \mathrm{Al}$ and $\mathrm{Fe}$, as determined by $\mathrm{X}$-ray diffraction and $\mathrm{EDX}$ spot analyses (see Facies 4). In some cases, millimetre-thick alternations of Spherulitic Crusts (see section 6) and $\mathrm{Mg}$-Si bands were recognised. Amorphous $\mathrm{Mg}$-Si phases are commonly replaced by ferroan blocky to granular calcite cements following vein-like structures (FIG. 5B). This facies was identified in the central part of the quarry (BH-2 and EK-1, Fig. 7) being very rare in the SE part. 


\subsection{Facies 3: Shrubby carbonate build-upsSpherulitic cementstone}

This facies is represented by up to $2 \mathrm{~m}$-thick and $3 \mathrm{~m}$-wide, dark grey, un-fossiliferous

carbonate units with distinctive dome-shaped to lenticular morphologies and limited lateral

continuity towards the SSE of the quarry (FIG. 5C, D, E). According to Clarkson et al., (1993)

this facies extended laterally at least $50 \mathrm{~m}$ to the west of BH-2 (Fig. 7). Two main metre-thick

shrubby-build-up intervals were identified in BH-2 and EK-1, although tiny centimetre-thick layers were reported interbedded within Facies 1 (EK-1). This facies is sandwiched between Facies 1 and 4 (FIG. 5C, D), and in some outcrops it passes laterally into Facies 2 (seen in BH-2 and EK-1, Fig. 7). Shrubby-Spherulitic cementstone build-ups-encompass a 'clotted' carbonate texture formed by calcite stacked fan ealeite-fabrics (see Section 6) and developing millimetre to centimetre-sized, crackle to mosaic pack-breccias filled by pale white siliea quartz/chalcedony cements (FIG. 5F). This facies was only recorded in the NW and central part of the quarry and it is equivalent to the 'Massive limestones' of Muir and Walton (1957) and Rolfe et al. (1993).

\subsection{Facies 4: Volcanic tuffs and intraclastic calcareous tuffs}

This facies consists of $5 \mathrm{~cm}$ to $5 \mathrm{~m}$-thick, green to yellow, nodular and discontinuous beds of epiclastic tuffs interbedded throughout the entire succession, though more abundant and thicker units were identified at the top of the sequence (Fig. 7). These deposits can reach up to 7 m-thick in BH-1 and 3.3 m-thick in BH-2. Volcanic tuffs display a fabric of coarsegrained lapilli clasts (up to $15 \mathrm{~mm}$ in diameter) floating in poorly sorted fine-grained vesicular or amygdaloidal ash with shards (FIG. 6A left). Lapilli clasts exhibit a porphyritic 
273

fabric of plagioclase, augite, olivine and magnetite phenocrysts (Fig. 6B). Calcite

274 pseudomorphs after olivine are also present. EDX spot analyses of lapilli show an-abundance of $\mathrm{Al}$, $\mathrm{Ti}$ and $\mathrm{Ca}$, and minor amounts of $\mathrm{K}, \mathrm{Mg}$ and $\mathrm{Fe}$ (FIG. 6D). Petrographic and chemical

276 analysis points to a basaltic to basanitic composition. Furthermore, centimetre to decimetre277 thick (averaging $20 \mathrm{~cm}$ in thickness), greenish to dark grey, heterogeneous layers of 278 intraclastic calcareous tuffs were systematically recorded systematically-intercalated within 279 Facies 1 in EK-1 and 2, and BH-1, 2 and 3 (Fig. 6A right; Fig. 7). These layers display sharp 280 and erosive basal contacts, normal grading and load casts. Coarse grained intervals Intraclastic

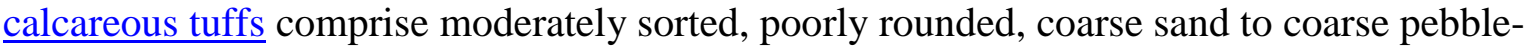
282 sized fragments of volcanic tuffs, coarse sand-sized spherulitic grains and intraclastic 283 carbonate laminae (Facies 1) embedded in , and-submillimetre-thick patches of irregularly banded amorphous Mg-Si minerals (kaolinite-serpentine group) as indicated by X-ray

\subsection{Facies 5: Layered carbonatesIntraclastic wackestone-floatstone}

This facies comprises centimetre to decimetre-thick (up to $15 \mathrm{~cm}--$ thick) continuous, nodular to tabular wackestone to floatstone layers (Fig. 6E, F) commonly observed in the upper parts of EK-2 and BH-3, but decreasing in abundance towards the NW of the quarry (FIG. 7). In some cases normal graded beds (wackestone grading to floatstone), and macroscopic and microscopic evidence of soft-sediment deformation was identified (slumps and convolute beds). Carbonate allochems comprise millimetre-sized contorted laminae intraclasts (Facies 
1), peloids, fish scales, ostracod shells, and very rare spherulitic components floating in a micritic matrix. SEM BSE analyses reveal abundant euhedral pyrite framboids (up to $6 \mu \mathrm{m}$ in diameter), and kerogenous matter both within laminae intraclasts and the carbonate matrix.

This facies is partially equivalent to the Little Cliff Shale of Rolfe et al. (1993).

\subsection{Facies 6: Shales}

This facies is constituted by up to 6 m-thick, blue-grey, laterally variable, organic-rich shales (Fig. 5E). They were recognised in the upper parts of BH-1, BH-3 and EK-2, thinning laterally northwards (Fig. 7). This faciesIt contains sporadic thin continuous horizons of centimetre-thick ironstone bands and concretions forming thin continuous horizens, and a wide array of fossiliferous remains such as bivalves (Curvirimula scotica), fish scales and skeletons (actinopterygians, acanthodians, and sharks), ostracod shells (Carbonita), arthropod cuticles, spores, lycopsids (Lepidodendron), and other foliage remains (Rolfe et al., 1993; Clarkson et al., 1993). Shales alternate with Facies 5 as seen in EK-2 (Fig. 6E5F) though Facies 4 can also be sporadically interbedded within shales (e.g. $\mathrm{BH}-1)$. This facies is comparable to the 'Little Cliff Shale' described by Rolfe et al. (1993).

\section{FACIES SUCCESSIONS}

At outcrop and borehole scale, lithofacies are stacked repeatedly, forming metre-thick smallscale, usually asymmetrical cycles (Fig. 7, 8). These elementary cycles can be viewed as parasequences (sensu Spence and Tucker, 2007).--The East Kirkton sedimentary succession is built by tThe stacking of these basic unitscycles build up the East Kirkton-sedimentary strcession. Parasequences-which were distinguished on the basis of their bounding surfaces 
and/or abrupt facies changes. F, and four types were recognised across the carbonate system

324

\subsection{Type-A Parasequence $\underline{\text { Cycle }}$}

The thickness of this asymmetrical cycle varies between 1 and 3 _m. It is composed of millimetre to centimetre-thick shaly layers (Facies 6) (FIG. 7, 8), followed by up to 2.5 -mthick shrubby carbenatespherulitic cementstone build-ups (Facies 3) which is sharply overlain by up to $1 \mathrm{~m}$-thick beds of grainstone-packstone of spherulitic grains (Facies 2).

331 Evidence for paleosols or paleokarst horizons is lacking, despite this parasequence-cycle was 332 appearing to locally develop on top of an erosional surface eneenformity (as seen in EK-1).

333 This type of parasequence cycle can contain up to $15 \mathrm{~cm}$-thick intraclastic calcareous tuff 334 layers (Facies 4) intercalated within Facies 2, centimetre-thick levels of grainstone-packstone 335 of spherulitic grains (Facies 2) and rare centimetre-thick spherulitic-shaly limestone beds 336 (Facies 6) intermingled within Facies 3. Type-A parasequences cycles were exclusively 337 recorded in the NW part of the quarry (EK-1 and BH-2, Fig. 7).

\subsection{Type-B parasequenceCycle}

This type of cycle parasequence-is constituted by up to 1.5 m-thick strata bounded by sharp surfaces and forming asymmetrical eyclessequences (Fig. 7, 8). They are constituted by a lower part of up to $1.1 \mathrm{~m}$-thick spherulitic laminite beds (Facies 1) grading upwards towards up to $40 \mathrm{~cm}$-thick of grainstone-packstone of spherulitic grains (Facies 2). Type-B parasequences cycles were only recognised in the central part of the quarry (EK-1) (Fig. 7).

\subsection{Type-C parasequence $\underline{\text { Cycle }}$}


These basic accretional units are made up of 1 to 3 m-thick packages bounded by sharp flooding surfaces. This asymmetrical parasequence cycle is composed by a lower portion of up to 1 _m-thick (typically $<25 \mathrm{~cm}$-thick) organic-rich shales (Facies 6) commonly overlain by up to 2_m-thick upper portion constituted by coarse-grained calcareous tuffs (Facies 4) grading to spherulitic laminites (Facies 1) (Type-C1, Fig. 7, 8). Facies 4 tend to show basal sharp erosional surfaces or undulating contacts due to plastic buckling on top of shale beds. In some cycles, laminites are notably devoid of spherulitic grains defining Type-C2 cyclesparasequences. Type-C1 parasequences-cycles were recognised in the NW part of the quarry (BH-2, EK-1 and BH-1) while Type-C2 were identified in the SE region (BH-3 and EK-2) (Fig. 7).

\subsection{Type-D parasequence- $\underline{\text { Cycle }}$}

These elemental cycles are constituted by up to 6 - $\mathrm{m}$-thick strata bounded by sharp facies contrasts or flooding surfaces (Fig. 7, 8). They are organised by a metre-thick lower shalerich package (Facies 6) or laminites with absence of spherulitic grains (Facies 1) occasionally alternating with centimetre-thick intraclastic calcareous tuff levels (Facies 4), and an upper interval formed by an alternation of intraclastic wackestone-floatstone layered carbenates (Facies 5) and shales (Facies 6). Type-D cycles parasequences-were preferentially recorded in the upper and SSE part of the quarry (EK-2 and BH-3) (Fig. 7).

\section{PETROGRAPHY OF SPHERULITIC COMPONENTS}

Spherulitic components are characterised by a recurrent combination of several crystal fabrics:

Fibrous Calcite, Spherulitic Calcite, Botryoidal Calcite, and Subhedral Silica (Table 2). 
372

The Fibrous Calcite (sensu Schroeder, 1972; Longman, 1980, or Mazzullo, 1980) (FIG. 9A) consists of needle-like and radially divergent crystals with length-to-width ratio of $\sim 9.2: 1$ (>6:1 according to Folk, 1965) and typically average lengths and widths of $\sim 83 \_\mu \mathrm{m}$ and $\sim 9$ $\mu \mathrm{m}$ respectively. In some cases, pervasive corrosion followed by silica replacement obliterated the characteristic fibrous terminations (FIG. 9A).

Spherulitic Calcite (sensu Schroeder, 1972; Davies, 1977, or Verrecchia et al., 19985) is made up of dense spheroidal to botryoidal coatings constituted by elongated, rectilinear fibroradial calcite polycrystals with their $c$ axes radiating from a previous substrate, and exhibiting sweeping extinction (FIG. 9B, C, D; 10A, C). A characteristic feature of Spherulitic Calcite crystals is their epitaxial growth on top of Fibrous Calcite, or other Spherulitic Calcite bodies (Fig. 9A, 9F). Polycrystals in Spherulitic Cealcite pelyerystals-are between $\underline{80 \mu \mathrm{m} \text { to } 2 \mathrm{~mm}-}$ length $100 \mu \mathrm{m}$ to $1 \mathrm{~mm}-$ length and up to $\sim 10 \mu \mathrm{m}$-width. Trace element analyses indieate a low-Mg ferran eompition (average Mg content $14345 \mathrm{ppm}$ ), and Sr, Fe and Mn eencentrations averaging 11500,3400 and 390 ppm respectively (Walkden al., 1993). Botryoidal Calcite (sensu Davies, 1977; Ginsburg and James, 1976) is comprised by elongated and radially divergent calcite polycrystals $(80 \mu \mathrm{m}$ to $2 \mathrm{~mm}$ - length, and up to -10 Hm-width in average) generating botryoidal fans with sweeping extinetion (FIG. 9C). Botryoidal fans are nucleated upon previous surfaces and competitive crystal growth between fans is observed (FIG. 9C).Spherulitic Calcite and Botryoidal Caleite-coatings exhibit corrosion scars characterised by dentate or irregular surfaces (FIG. 9D, E). Younger generations of these fabrics were nucleated on previous surfaces, and sometimes they grew in optical and lattice continuity with the older crystals. In so doing they left subtle concentric lines between each growth stage (FIG. 9F). Trace element data shows a low Mg ferroan ealeite composition (average $\mathrm{Mg}$ content of 10550ppm), and $\mathrm{Sr}$, Fe and Mn cencentrations averaging 8690,5097 , and 600ppm respectively according to Walkden et al. (1993). Trace 
element analyses indicate a tow-Mg ferroan composition (average Mg content of $14345 \mathrm{ppm}$ ), and Sr, Fe and Mn concentrations averaging 11500, 3400 and 390ppm respectively (Walkden et al., 1993).

Subhedral Silica is recognised as up to $40 \mu \mathrm{m}$ diameter crystals that exhibit single-crystal and undulose extinction (FIG. 9A, C; 10D up) and partially seen replacinged Fibrous Calcite, and less commonly replacinged Spherulitic or Botryoidal-Calcite.

\subsection{Petrography of Spherulitic Coated Grains}

In two-dimensional sections, these grains display diverse sizes and morphologies (Table 2). Two types of particles were recognised according to their outlines. Around $85 \%$ are Type 1 Coated Grains, described as circular to sub-circular (50 to $700 \mu$ m-diameter) with rounded to sub-rounded corners and edges, and irregular and/or abraded outlines (FIG. 9B, 10A, C). The remaining $15 \%$ are Type 2 Coated Grains, which have elongated outlines (up to $4 \mathrm{~mm}$ length) and similar roundness and irregularities to Type 1 (FIG. 9C, 10C, D). Most grains have allochthonous particles in their cores, commonly lycopsids, ferns, gymnosperms or algal fragments, and less frequently volcanic grains and peloids (FIG. 10D). Core dimensions average between $50 \mu \mathrm{m}$ to $3 \mathrm{~mm}$ in length and their shape are curled, elongated or subcircular.

Physical characteristics of cores are closely linked to the final external morphology of these grains. Type 1 exhibit arcuate to spheroidal cores such as foliage particles and ash fragments of $50 \mu \mathrm{m}$ to $700 \mu \mathrm{m}$ in length, and length to width (L:W) ratios of 2:1 (Fig. 4E; 9B). Type 2 have elongated and non-spheroidal cores such as plant debris with lengths up to $4 \mathrm{~mm}$, and L:W ratios $>2: 1$ (Fig 9C, 10D). Although some grains appear to lack cores, this likely reflects 
that the plane of the thin-section did not cut through the particle core, or that core size was

\subsection{Petrography of Spherulitic Crusts} and lattice continuity around a core (FIG. 9F). dentate outlines (FIG. 10C). FIGURE. 9 and 10 HEREABOUTS =

Spherulitic Coated Grains are composed of Fibrous Calcite, Subhedral Silica, and Spherulitic Calcite-or Botryoidal Calcite fabrics. Microscopy including SEM-EDX analyses revealed the absence of Mg-Si mineral inclusions within Spherulitic and BotryoidalCalcite. Fibrous Calcite formed widespread calcite fringe coatings that nucleated on and grew normal to the core surface (FIG. 9A and 10D). Spherulitic Calcite or Botryoidal Calcite-wasere epitaxially nucleated upon Fibrous Calcite templates or on antecedent Spherulitice Calcite coatings. In some cases, pervasive corrosion of these crystals is later filled by Subhedral Silica. This adversely affected the continuity and terminations of fibrous crystals (FIG. 9A, C and 10D). Type 1 grains were dominated by Spherulitic Calcite adopting spheroidal coatings, whereas non-spheroidal, elongated Type 2 grains were normally made of Spherulitic Botryoidat Calcite displaying botryoidal fan-shaped coatings. 'Oncoidal' forms were represented by the $<5 \%$ of studied grains where concentric generations of Spherulitice Calcite grew in optical

Some Spherulitic Calcite fibres experienced deflection during later stages of growth, and this is visible where crystals reached $>1 \mathrm{~mm}$ in length (FIG. 10A, B). These deviations imparted arcuate crystal terminations to the spherules. Some other grains have polished, and irregularly 
These crusts (FIG. 11; Table 2) are made up of a first generation of Fibrous Calcite fabrics

nucleating from core nuclei, and a second phase constituted by Spherulitic Calcite.

Spherulitic Calcite encapsulated carbonaceous filaments (mono-specific, dark brown, double walled filamentous structures and their fragments) (FIG. 11A to D). Preserved carbonaceous filaments displayed circular to prismatic outlines in transverse cross-sections $\left(\sim 50 \_\mu \mathrm{m}\right.$ in diameter) and elongated, parallel and smooth outlines in longitudinal cross-sections (at least 4 $\mathrm{mm}$ in length). Outer boundaries of Spherulitic Calcite bundles overlap and are fused together, defining distinct planes (FIG. 11D). These planes display dissolution cavities filled by $\mathrm{Mg}-\mathrm{Si}$ phases-minerals that in turn wereas replaced by younger Spherulitic Calcite (FIG. 11C, D). Spherulitic Crusts were overlain by filament-free Mg-Si-rich layers (FIG. 11A).

Circular to sub-circular abraded fragments of Spherulitic Crusts were found in Facies 1 and 4. In these cases, the tubular moulds left by the decay of the filamentous inclusions became filled by sparite (FIG. 11E, left) or amorphous Mg-Si minerals (FIG. 11E, right). Crusts were also seen growing around nuclei made of coated grains (FIG. 11F). Deflection of calcite fibres around algae objects was eømmon-observed (Fig. 11F, inset)

\subsection{Petrography of Spherulitic Intraclasts}

Two types of Spherulitic Intraclasts were recognised: Type 1 (90\% in abundance), submillimetre-sized individual objects, and Type 2 (10\% in abundance), millimetre-sized tubiform objects (FIG. 12; Table 2).

Type 1 comprised elongated particles (100 to 500 $\mu \mathrm{m}$ long) constituted by laterally stacked Botryoidat-Spherulitic Calcite fans. Each intraclast measured up to $20-30 \mu \mathrm{m}$ in width and most exhibited flat and smooth bases (Fig. 12A). Some bases had slightly irregular and 
corroded boundaries. Type 2 comprised individual tubiform particles reached $4 \mathrm{~mm}$ in length,

and up to 2 mm in width, each exhibiting an outer layer of laterally and vertically-stacked Spherulitic BotryoidalCalcite. The latter have dimensions of 100 to $500 \mu \mu \mathrm{m}$ in width (Fig. 12B, C). In some cases, corrosion cavities within Spherulitic Intraclasts were filled by Spherulitic Crusts (FIG. 12C, D, E). Spherulitic BotryoidatCalcite fans can rarely incorporate fragments of carbonaceous filaments. In such cases, calcite fibres around filaments displayed deflected growth trajectories (FIG. 12F).

\subsection{Petrography of Stacked Fans}

Carbonate 'clots' of Facies 3 (Spherulitic cementstones) are constituted by 'shrubbotryoidallike' growths of laterally and vertically-stacked Spherulitic BotryoidatCalcite. Individual fans reach 100 to $1000 \_\mu$ m--thick, and 100 to $3000 \_\mu \mathrm{m}$ in width (FIG. 13; Table 2).

Composites of laterally-aligned fans have lengths of several centimetres. Some Spherulitic Coated Grains served as initiation points for these fans. Scalloped solution pits and vertical cracks up to $200 \mu \mathrm{m}$ deep were observed on top surfaces (Fig. 13B, C). These corroded areas were successively epitaxially covered by lighter and turbid and pale brown $\underline{\text { Spherulitic }}$ BotryoidatCalcite (FIG. 13D). In some cases, chert replaced corroded fans (FIG. 13E). 10 to $50 \mu \mathrm{m}$-thick continuous silica laminae separates some of the Spherulitic Botryoidal-Calcite fans (FIG. 13C). Centimetre-sized crackle to mosaic pack-breccia interclast voids were filled with fibro-radial ehert chalcedony cement (FIG. 13F).

Though Goodacre (1999) identified filamentous carbonaceous inclusions within stacked fans that were-attributed to cyanobacterial remains, none were found in our samples, resulting in similar calcitic 'shrubby' textures to those illustrated in 'Pre-Salt' Campos Basin (Herlinger, 
2016). However, intra-crystalline micro-porosity filled by kerogenous matter was observed in

\section{FIGURE. 13 HEREABOUTS}

\section{DISCUSSION}

\subsection{Geochemical considerations}

The occurrence of amorphous magnesium-silicate minerals in association with intraclastic calcareous tuffs (Facies 4) is not surprising. Alteration of Mg-rich silicates (e.g., pyroxene or olivine) from alkaline and ultramafic igneous rocks can have generated a range of $\mathrm{Mg} /-\mathrm{Si}_{-}$ rich phyllosilicate phases such those ebserved-recorded in East Kirkton and probably in the 'Pre-salt' lacustrine basins (Rogerson et al., 2017). According to XRD and EDX analyses such Mg-Si phases are compositionally similar to minerals of the kaolinite-(a-serpentine group like', product according to $\mathrm{XRD}$ analyses $\left[(\mathrm{Mg}, \mathrm{Fe})_{3} \underline{\mathrm{Si}}_{2} \underline{\mathrm{O}}_{5} \underline{(\mathrm{OH}}_{4}\right]+$. Climatic influenced wWeathering by infiltrating waterprocesses may have favoured-triggered the hydrolysis of basaltic lavas favouring the formation of of the Bathgate Hills voleanie formationhydrous magnesium iron phyllosilicates (see Rogerson et al., 2017Smith et al., 1993; Whyte 1993). A tropical and humid climate is supported by the abundant lycopod and fern vegetation surrounding the lake margins (Clarkson et al., 1993; Scott et al., 1993). Furthermore, water-rock weathering interactions can have raised the $\mathrm{pH}$ and increased the alkalinity of the aqueous solutions sourcing the East Kirkton lake (Pecoraino et al., 2015; Deocampo and Renaut, 2016;). The abundance of permeable tuffaceous voleanics and voleanic ash may have Eenhanced the surface area available forsusbtrate hydrolysis and canthe release ef-alkali cations in solution $(\mathrm{Ca}, \mathrm{Mg}, \mathrm{Sr})$ encouraging elevated $\mathrm{CaCO}_{3}$ supersaturation in the lake waters_(Rogerson et al., 2017). Moreover, the East Kirkton 
521

carbonates (laminites and spherulitic components) showed high trace element contents ( $\mathrm{Sr}, \mathrm{Fe}$ and $\mathrm{Mn}$ ), and alse- $\delta^{18} \mathrm{O}_{\text {calcite }}$ values of $\left(-11\right.$ to $\left.-2 \%_{2}\right)$ and $\delta^{13} \mathrm{C}_{\text {calcite }}$ values of $(0$ to $4 \%$ ) values globally indicating precipitation in a meteoric-sourced, dysaerobic to anoxic, volcanic lake (Walkden et al., 1993). The lack of evaporite minerals and the depleted $\delta^{18} \mathrm{O}_{\text {calcite }}$ values questions whether the lake had persistent salinity departures.

\subsection{Diagenesis and trace element concentrations}

Subhedral Silica is usually replacing early Fibrous Calcite in those spherules encapsulating carbonaceous filaments. Filament decay may have generated favourable conduits for the circulation of silica fluids into the permeable organic cores producing enhanced silicification within and around Fibrous Calcite crystals soon after spherule formation (Fig. 14). In addition, amorphous silica lamina in laminite facies was interpreted as primary in origin via formation of silica gels because: 1) plastic deformation of slumped silica laminae show no evidence of fracturing, 2) silica laminae is cut by tiny perpendicular cracks leaving the overlying laminae unaffected (sensu McGill, 1994) (Fig. 4B).

Furthermore, the Spherulitic Calcite textures show no evidence of an original aragonite precursor neither the presence of neomorphic calcite fabrics selectively replacing aragonite. Strikingly, spherulitic fabrics contain high $\mathrm{Mg}$ and $\mathrm{Sr}$ concentrations as occur in the 'Pre-salt' shrubby carbonates where calcite was hypothesised to be directly precipitated from alkaline lake waters (Saller et al., 2016). Enhanced strontium uptake into calcite minerals originally precipitated in low-temperature alkaline experiments has been reported via initial formation of amorphous calcium carbonate (ACC) precursor phases (Littlewood, et al., 2017). The presence of dissolved $\mathrm{Mg}^{2+}$ ions can further stabilise ACC phases thus promoting $\mathrm{Sr}^{2+}$ incorporation (Rodríguez-Blanco et al., 2012) and favouring the direct transformation of 
ACC into calcite crystals (Loste et al., 2003; Rodríguez-Blanco et al., 2012) with highmagnesium contents (Raz et al., 2000; Wang et al., 2012). The initial formation of ACC can be achieved in moderate to high alkalinity environments with concomitant high $\mathrm{Mg}: \mathrm{Ca}$ contents (Wang et al., 2012) turning alkaline lake chemistries suitable for potential primary precipitation of high-Mg calcites.

\subsection{Sedimentology of spherulitic components}

The isopachous calcite rims of Fibrous Calcite grew upon organic cores in conditions

favourable for crystal nucleation. Such conditions may have included elevated $\mathrm{pH}$ and high alkalinity linked to high $\mathrm{CaCO}_{3}$ supersaturation, perhaps coupled with active water agitation (e.g. Schroeder, 1972; Longman, 1980) and an-abundance of loose carbonaceous material to form cores (Fig. 14). Both-The epitaxial growth of Spherulitic and Botryoidal-Calcite grew-on top ofepitaxially on Fibrous Calcite indicatesing that the crystalline substrate played a role in the development of these fabrics (Fig. 14). Indeed, the shape of the cores in Spherulitic Coated Grains (Type 1 and Type 2) seemingly dictated the final external morphology (FIG. 10C). Absence of evidence for clay or volcaniclastic inclusions within Spherulitic and BotryoidatCalcite suggest that Spherulitic Coated Grains developed at the sediment-water interface rather than within the sediment. Absence of conspicuous biological inclusions further suggests that the type of microbial communities thriving at the time of spherule formation did not leave noticeable organic remains. Evidence of clay cavity-filling textures within spherules is here consistent with late corrosion processes. All of this evidence points to a depositional environment capable of forming packstone, grainstone and floatstone of Spherulitic Coated Grains regularly agitated by currents and supplied by plant debris (common nuclei) at or above the sediment-water interface. 
Conversely, Spherulitic Crusts were characterised by their_tendedency to incorporate

filamentous components into their crystal structure. Petrographic analysis suggests that

Spherulitic Crusts grew within an intertwined framework of filamentous green algae

(Cladophora-like) (FIG. 11C, 15). Deviation of the Spherulitic Calcite growth trajectories in proximity to algal fragments further suggests that crystallite trajectories were affected by the presence of these objects (Fig. 11F). Overlapping of crystal fans is compatible with competitive growth of Spherulitic Calcite bundles that ceased when remaining space was filled. Lack of sediment inclusions indicates that growth occurred above the sediment-water interface (Fig. 15). In the East Kirkton Lake, very rare Mg-Si mineral occurrences were recognised and these were found overlaying spherulitic crusts (Fig. 10A). Such phyllosilicate layers were largely devoid of carbonaceous filaments, consistent with a cessation of algal production during Mg-Si presence (Fig. 11A; 15). FIGURE. 15 HEREABOUTS

The Botryoidat-Spherulitic Calcite forming Spherulitic Intraclasts are likely calcite encrustations on the external surfaces of subaquatic plants and algae or within internal cavities producing laterally-linked botryoids (Type 1) (FIG. 16). Similarly, tubular spherulitic aggregates may have originally encrusted macro-algal thallae (Type 2). Subsequent reworking of the organic templates may have generated intraclastic textures seen in thin sections (FIG. 12, 16). The predominance of packstone-grainstone textures supports the contention that water agitation was a factor in their accumulation. Similar fibro-radial crystals have been reported as forming attached to the trichomes of freshwater cyanobacterium Nostoc parmelioides (Freytet and Verrecchia, 1993), filling the axial voids of the freshwater 
algae Zarramenella minorica (Freytet et al., 1999), or the lysed cells of the green-alga

Cladophoropsis (Arp et al., 2003).

\section{FIGURE. 16 HEREABOUTS}

Stacked Fan nucleation and growth likely required a static substrate (FIG. 17), and these

facies may be partially analogous to stacked botryoidal micro-stromatolitic crusts (20 to

$60 \mu m_{-}-t h i c k$ ) and globular aragonitic fans of Satonda Lake, Indonesia (Arp et al., 2003). The crusts of Arp et al. (2003) veneered the outer moulds of green algal filaments and were terminated by smooth, undulating surfaces. East Kirkton Stacked Fans, however, lacked noticeable organic filaments (although these are reported-mentioned by Goodacre, 1999), which raises questions over the spatial organisation of active calcite growth and the microbes that will inevitably have been present within this site.

Petrography shows epitaxial Botryoidat-Spherulitic Calcite nucleated on previously corroded fans (Fig. 13D), indicating that corrosion occurred during growth of Botryoidal Calcite fabriesstages, and that sustainable conditions for Botryoidat-Spherulitic Calcite growth reemerged after short-lived dissolution events (FIG. 17). Lack of clay or volcaniclastic materials within Stacked Fans suggests that they may have formed in an agitated subaqueous environment.

\subsection{Parasequence Cyclostratigraphy architecture-and depositional model}

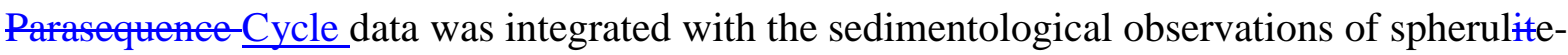
bearing lithofacies (Fig. 7) and spherulitic components (Fig. 14 to 17). This alloweding the 
reconstruction of thea refined_depositional model for the East Kirkton sedimentary succession (Fig. 18) and =comparisons with the 'Pre-salt' cyclostratigraphic data.

\section{7.ł.1. Littoral environment}

Type-A cycles parasequences-characterise the shallower lake environments where carbonate production took place in moderate to high energy conditions, perhaps in the littoral to proximal sublittoral setting towards the lake centre. This environment was located on the NNW side of the quarry (Fig 7). Type-A cycles parasequences-reflect an initial transgressive phase (Facies 6) overlain by a regressive spherulite-dominated stage (Facies 2 and 3) (Fig 7). The sporadic occurrence of poorly sorted spherulitic grainstone to packstone on top of these cycles points to intermittent low-energy periods enabling co-occurrence with $\mathrm{Mg}$-Si minerals. Spherulitic Coated Grains, Spherulitic Crusts, and Spherulitic Intraclasts were penecontemporaneously nucleated in this setting, which hosted the optimal conditions for

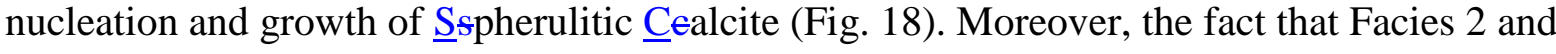
3 are laterally linked or intermingled suggest that they formed in close temporal association.

The local erosional truncation underlying Type-A cycles parasequences-likely reflects a phase of lake contraction followed by the development of shrubby spherulitic cementstone earbonate-build-ups during a resumed lake re-flooding (Fig. 7, 8). Intermittent input of undersaturated waters into the lake (sensu Driscoll and Newton, 1985; Reuss et al., 1987) could explain some early dissolution features in spherulitic textures. McGill (1994) and Walkden et al. (1993) documented cathodoluminiscence banding in spherulitic components that would be coherent with $\underline{\mathrm{E}}_{\mathrm{H}-\mathrm{pH}} \mathrm{H}$ variations of the fluids forming these grains. The shallow water, high energy setting and simultaneous development of shrubby and-spherulitic cementstones growths-of East Kirkton compares well with similar the 'Pre-Salt' shrubby microbial boundstones from Brazil and Angola, (Saller et al., 2016; Sabato Ceraldi and Green, 

2016). In East Kirkton, Type-A cycles are similar to those described for the 'Pre-salt' by

Wright and Barnett (2015), and Sabato Ceraldi and Green (2016). In the latter cases, the laminated argillaceous mudstone is placed at the beginning of the cyclothems (Wright and Barnett, 2015) and considered as formed during transgressive pulses (sensu Sabato Ceraldi and Green, 2016) as similarly occur with Facies 6 in this work. In some 'Pre-salt' cycles the occurrence of thin spherulitic grainstone with intraclastic shrub material has been reported underlying the laminated mudstone indicating potentially active reworking events before deposition of muddy facies. In the Scottish cycles spherulitic grainstone to packstone represents the most regressive parts accumulated on top of spherulitic cementstone packages or even occurring intermingled within them suggesting a close origin for both facies.

\subsubsection{Sublittoral to shallow profundal environment}

Type-B and C cycles parasequences-define the littoral to sublittoral settings respectively, which were located in the central part of the quarry (Fig 7). Type-B cycles parasequences show an initial deepening phase (Facies 1), and a subsequent shallowing phase (Facies 2). More distal Type-C cycles parasequences-(C1 and $\mathrm{C} 2)$ display a transgressive pulse (Facies 6), and a regressive stage formed by the stacking of Facies 1 and 4 . Normal graded beds with erosive bases are best interpreted as pulses of downslope sediment gravity transport triggered by slumping processes (e.g., Lowe, 1979) generated during regressive intervals (Fig 7, 8). The fold axes of slumps and convolute beds are similarly grouped sub-parallel to one another and parallel to the inferred paleo-slope strike suggesting that soft-sediment deformation (slumping and convolute laminae) was likely triggered by slope gradients to the WNW (Woodcock, 1979; Strachan and Alsop, 2006) (Fig. 7B, Fig. 18). 
671 Sub-millimetre scale continuous laminae formed under low energy depositional conditions

672 with limited siliciclastic input. Carbonate laminae are 2 to 4 times thicker than organic

673 laminae, suggesting either brief intervals of carbonate-free sedimentation interrupting

674 ongoing calcite production triggered by photosynthesis in the water column (sensu Dittrich 675 and Obst, 2004) or else organic sedimentation being slow relative to carbonate accumulation 676 in this setting. Evidence of chipped and polished spherulitic grains, and abraded spherulitic

crust fragments within Type-B and C1 cycles parasequences-points to reworking of these components from the shallow lake factory areas (Fig. 18). Likewise, in the 'Pre-Salt' sag lakes clay-rich spherulitic facies tend to occur in deeper environments below the platform margin where lower energy enabled the deposition of finer-grained sediments (Saller et al., 2016; Sabato Ceraldi and Green, 2016). Thus 'Pre-salt' cycles show spherule-stevensite floatstone packages capped by calcite shrubs framestone beds (Wright and Barnett, 2015) or $\underline{\text { microbial crusts-reworked spherules in an upward regressive trend (sensu Sabato Ceraldi and }}$ Green, 2016). Type-B cycles in East Kirkton show similar stratal arrangement though low energy intervals are here dominated by laminites instead of substantial clay beds. Pinching out of organic laminae against spherulitic grains further indicates that East Kirkton grains were systematically buried by muddy sediments (Fig. 4E). Type-_C2 cycles parasequences-are apparently devoid of spherulitic grains indicating deposition of laminites in deeper environments than Type_-C1 (Fig 7). The occurrence of pyrite framboids, preserved biota, absence of bioturbation, and trace element geochemistry (Clarkson et al., 1993; Rolfe et al., 1993; Scott et al., 1993) is consistent with low oxygen conditions.

\subsubsection{Profundal environment \\ Type-D cycles parasequences-indicate sedimentation in a profundal lake setting under low energy conditions found predominantly in the SE part of the quarry (Fig. 7, 18). These cycles}


parasequences-display an initial shale-rich deepening interval (Facies 6) followed by carbonate-rich shallowing intervals (Facies 5) (Fig 7). Graded and convolute beds are evidence for gravity flows and reworking of semi-consolidated layers from lake margins to depocentres. Preservation of pyrite framboids and fauna and flora indicates conditions of water stagnation and oxygen depletion. These features imply the bottom was well below lake wave base, which is reliable with earlier suggestions that the lake was of sufficient water depth to sustain sporadic meromictic conditions and support nektonic vertebrate life (Parnell, 1988; Loftus and Greensmith, 1988; Clarkson et al., 1993). Similar anoxic conditions were reported in the 'Pre-salt' lakes during the sag 2 microbial interval when organic-rich shales and marls were deposited in the deeper parts (Sabato Ceraldi and Green, 2016).

\subsection{Origin of Spherulitic and BotryoidatCalcite: microbes versus stevensite}

Nucleation of Spherulitic and BotryoidalCalcite is a phenomenon that has been linked to bacterial and cyanobacterial activity, as demonstrated through laboratory experimentation (Buczynski and Chafetz, 1993; Verrecchia et al., 1995; González-Muñoz et al., 2000; Braissant et al., 2003; Ercole et al., 2007; Rodríguez-Navarro et al., 2007; Sánchez-Navas et al., 2009; Pedley et al., 2009). Microbial physiological processes (see Arp et al., 2003; Dupraz et al., 2009; Decho 2010) can alter the subaqueous carbonate equilibrium to effectively promote calcium carbonate precipitation that in some cases exhibits spherulitic morphologies (Verrecchia et al., 1995; Rodríguez-Navarro et al., 2007; Arp et al., 2012). However, in hyper-saline and caleium-limitedalkaline systems these metabolic activities are less likely to stimulate substantial calcification (Arp et al., 2001; 2012). In these settings bacterial degradation of the biofilm EPS significantly increases supersaturation and promote 
calcification (Arp et al., 1999; Dupraz, et al., 2009; Decho, 2010). Indeed, fibrous and radially-divergent aragonite layers are interpreted from lysed green algal structures in Satonda Lake (Arp et al., 2003). Similarly, millimetre-sized aragonite spherulites grew and accumulated within deeper parts of cyanobacterial mats in the Recent Kiritimati Lake where progressive EPS degradation was attributed to spherulite formation (Arp et al., 2012). In all these cases, calcite precipitation will be occurring in environments rich in dissolved EPS, which have been demonstrated to promote spherulite formation (Braissant et al., 2003, Wolthers et al., 2008; Mercedes-Martín et al., 2016). This mechanism is highly likely to be responsible for the abundant spherulitic carbonates at East Kirkton, and the absence of fossilised bacteria suggesting that calcite mineralisation is forming within degrading EPS_gels rather than within actively photosynthesising biofilms (sensu Trichet and Défarge, 1995; Arp et al., 2003; 2012) and in alkaline lakes (Walkden et al., 1993; Rogerson et al., 2017). Whether EPS molecules are produced from lake bottombenthic biofilms or being sedimented as polymer gels from planktic colloidal planktonic material onto the lake bottom (Decho, 1990; Hoagland et al., 1993; Passow et al., 2001; Passow, 2002) is unclear, but likely only

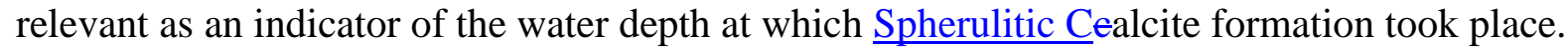
This mechanism is supported by the abundance of bacterial and micro-algal planktonic organisms known from the Midland Valley Carboniferous oil-shale lakes (Loftus and Greensmith, 1988; Parnell, 1988; Raymond ${ }_{2}$ 1991).

In the 'Pre-salt' lakes, stevensite clay was- invoked to participate in the growth of calcitic spherules (Tosca and Wright, 2015; Wright and Barnett, 2015). In East Kirkton, amorphous clay is limited to tiny occurrences in the sublittoral slope settings where chemical $(\mathrm{pH}$, alkalinity, saturation index) and physical (low energy) conditions enabled its formation and accumulation. At the same time, stevensite mineral formation is favoured at high $\mathrm{pH}$, high salinity and high $\mathrm{Mg} / \mathrm{Si}$ ratios (Tosca and Masterson, 2014) suggesting that the East Kirkton 
lake did not undergo such conditions in low energy zones. Interestingly, the occurrence of authigenic sparite in laminites (Fig. 4A) suggest that the sublittoral region was characterised by lower $\mathrm{pH} /$ saturation indexes than the littoral zone probably explaining why clay minerals were volumetrically rare. Nevertheless, examples such as the East Kirkton Limestone demonstrate that the formation of abundant spherulitic carbonates can be decoupled from clay influence in alkaline lakes and that 'microbial-solution' interactions warrant further research.

\section{7.ㅁ⒌ Further hHydrological implications}

The sedimentary record of the East Kirkton lake displays two incomplete, large-scale deepening-shallowing cycles bounded by an erosional surface interpreted as an (unconformity) interpreted to have formed in the littoral lake portion (Fig. 7, 8). These largerscale cycles may reflect a broad deepening pulse, as Type-C2 and D cycles parasequences-are progressively more abundant upwards in the sedimentary sequence (Fig 7). A change towards a more humid climate is recorded by the transition from gymnosperm to lycopsid vegetation in the lake margin (Scott et al., 1993), and from tetrapods-arthropods to fishes-ostracods within the lake water (Clarkson et al., 1993), thus the overall deepening trend of the lake appears to reflect increasing freshwater incursion. Variable freshwater input is also reflected in the wide spectrum of $\delta^{18} \mathrm{O}_{\text {calcite }}$ reported from the 'Pre-Salt' spherulitic carbonates of Brazil (-6 to 5\%o) and Angola ( -2 to 3\%), which fall within a broad range between fresher and more evaporative lake water conditions (Saller et al., 2016; Sabato Ceraldi and Green, 2016). Although the unusual carbonate phases of East Kirkton and the 'Pre-Salt' are certainly dependent on sufficiently high calcite supersaturation to form, this is apparently decoupled from evaporation. The lack of sulphates, chlorides, or their calcite/silica pseudomorphs even in the most regressive facies further indicates that the lake was not truly endorheic. It 
therefore seems unlikely that hydrological closure is-was a pivotal precondition for the development of calcitic spherulites (Saller et al., 2016; Sabato Ceraldi and Green, 2016)

\section{CONCLUSIONS}

1) A widespread assemblage of calcite spherulitic components (Coated Grains, Intraclasts,

Crusts, and Stacked Fans) were formed in a clay-poor, volcanic and alkaline lacustrine system.

2) The carbonate factory of spherulitic components was located in the littoral lake region (Fig.

18). This setting experienced a combination of high alkalinity, metal-rich hydrochemistry, and microbe-derived organic acid interference with the mineral formation process. These conditions collectively encouraged widespread Spherulitic and BotryoidalCalcite nucleation at the sediment-water interface.

3) Spherulitic Coated Grains were nucleated at the sediment-water interface on loose organic cores in an agitated environment (Fig. 14). Initial isopachous rims of Fibrous Calcite coated these cores. Spherulitic and BotryoidatCalcite grew epitaxially upon Fibrous Calcite giving the characteristic spheroidal shape to the grains. Spherulitic Crusts grew at the sedimentwater interface within an intertwined framework of filamentous green algae subsequently buried by amorphous Mg-Si matrices (Fig. 15). Spherulitic Intraclasts may have first formed as Botryoidat-Spherulitic Calcite bodies laterally encrusted to organic templates. Later reworking produced the intraclastic accumulations-texture (Fig. 16). Stacked Fans grew as laterally-stacked, Botryoidat-Spherulitic Calcite nucleated upon static substrates building

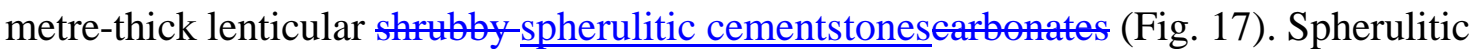
nucleation resumed upon corroded surfaces indicating that conditions of calcite supersaturation alternated with periods of undersaturation. Corrosive events are linked to input of fresher waters into the lake. 
795

4) Three lacustrine depositional settings were recognised: littoral, sublittoral, and profundal

\section{REFERENCES}

(Fig. 18). The littoral zone was characterised by coeval shrubby $\underline{\text { spherulitic }}$

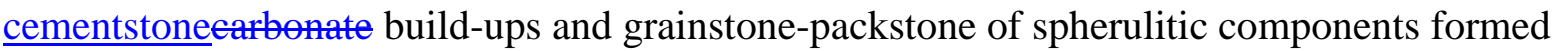
in well-agitated, shallow environment. The sublittoral zone was define by metric scale, slumped beds, and sediment gravity deposition triggered by slope gradients. Significant down-slope resedimentation of spherulitic grains allowed spherulitic laminites to form in the sublittoral to profundal region. The profundal setting was constituted by abundant carbonateshale alternations with highly preserved fossiliferous remains recording sporadic conditions of water stagnation, oxygen depletion and shedding episodes into lake depocentres.

\section{ACKNOWLEDGEMENTS}

BP Exploration Co. is thanked for funding, and particularly the Carbonate Team for supporting this research and for fruitful discussions. West Lothian Council and Scottish Natural Heritage are warmlythanked for allowing access and permission for sampling the site. Graham Tulloch (BGS Edinburgh), Nick Fraser (NMS), Tracey Gallagher and the Core Store Team at BGS Keyworth are particularly acknowledged for their assistance. Rona McGill is warmly kindly thanked for provide the photomosaic in Figure 3. Tony Sinclairis thanked for SEM sampling preparation and analysis., Mark Anderson (University of Hull), and Bouk Lacet (VU University Amsterdam) are thanked for producing sample preparation. $\underline{\text { Rthin sections.eviewers are warmly thanked for their detailed and valuable comments which }}$ help to sharpen the manuscript. Peir Pufahl is acknowledged for his constructive advice on an earlier draft, and Nereo Preto for his editorial assistance. 
Arp, G. Reimer, A. and Reitner, J. (2001). Photosynthesis-induced biofilm calcification and calcium concentrations in Phanerozoic oceans. Science 292, 1701-1704.

Arp, G., Helms, G., Karlinska, K., Schumann, G., Reimer, A., Reitner J. and Trichet. J. (2012). Photosynthesis versus exopolymer degradation in the formation of microbialites on the atoll of Kiritimati, Republic of Kiribati, Central Pacific. Geomicrobiology Journal, 29, 29-65

Arp, G., Reimer, A. and Reitner, J. (2003). Microbialite formation in seawater of increased alkalinity, Satonda Crater Lake, Indonesia. Journal of Sedimentary Research, 73, 105-127.

Arp, G., Thiel, V., Rimer, A., Michaelis, W. and Reitner, J. (1999). Biofilm exopolymers control microbialite formation at thermal springs discharging into alkaline Pyramid Lake, Nevada, USA. Sedimentary Geology, 126, 159-176.

Ayenew, T. (2008). Major ions composition of the groundwater and surface water systems and their geological and geochemical controls in the Ethiopian volcanic terrain. Ethiopian Journal of Science, 28, 171-188

Bahniuk, A. M., Anjos, S., França, A. B., Matsuda N., Eiler, J., Mckenzie, J. A. and Vasconcelos. C. (2015). Development of microbial carbonates in the Lower Cretaceous Codó Formation (north-east Brazil): Implications for interpretation of microbialite facies associations and palaeoenvironmental conditions. Sedimentology, 62, 155-181.

Bergner, A. G. N., Strecker, M. R., Trauth, M. H., Deino, A., Gasse, F., Blisniuk, P. and Dühnforth, M. (2009). Tectonic and climatic control on evolution of rift lakes in the Central Kenya Rift, East Africa. Quaternary Science Reviews, 25-26, 2804-2816.

Bertani, R. T. and Carozzi, A. V. (1985). Lagoa Feia Formation (Lower Cretaceous) Campos Basin, offshore Brazil: Rift Valley type lacustrine carbonate reservoirs - II. Journal of Petroleum Geology, 8, 199-220. 
Blott, S. J. and Pye, K. (2008). Particle shape: a review and new methods of characterization and classification. Sedimentology, 55, 31-63.

Bohacs, K. M., Carroll, A. R., Neal, J. E. and Mankiewicz, P. J. (2000). Lake-basin type, source potential, and hydrocarbon character: an integrated sequence-stratigraphicgeochemical framwework In: Lake basins through space and time (Eds E. H. GierlowskiKordesch, and K. Kelts. AAPG Studies in Geology 46, 3-37.

Bowser, C. J. and Jones, B. F. (2002). Mineralogic controls on the composition of natural waters dominated by silicate hydrolysis. American Journal of Science, 302, 582-662.

Braissant, O., Cailleau, G., Dupraz, C. and Verrecchia, E. P. (2003). Bacterially induced mineralization of calcium carbonate in terrestrial environments: the role of exopolysaccharides and amino acids. Journal of Sedimentary Research, 73, 485-490.

Browne, M. A. E. and Monro, S. K. (1989). Evolution of the coal basins of central Scotland. XIe Congrès International de Stratigraphie et de Géologie du Carbonifère. Compte Rendu $5,1-19$.

Bosak, T., and Newman, D. K. (2005). Microbial kinetic controls on calcite morphology in supersaturated solutions. Journal of Sedimentary Research, 75, $190-199$.

Buczynski, C. and Chafetz, H. S. (1993). Habit of bacterially induced precipitates of calcium carbonate: examples from laboratory experiments and recent sediments. In: Carbonate Microfacies (Eds. R. Rezak, D. L. Lavoie). Frontiers in Sedimentary Geology. pp 105-116

Burne, R. V., and Moore, L. S. (1987). Microbialites: organosedimentary deposits of benthic microbial communities. Palaios, 2, 241-254.

Cameron, I. B., Aitken, A.M., Browne, M.A.E. and Stephenson, D. (1998). Geology of the Falkirk district. Memoir of the British Geological Survey, Sheet 31E (Scotland). 
868 Carminatti, M., Wolff, B., and Gamboa, L. (2008). New exploratory frontiers in Brazil. 19th World Petroleum Congress. World Petroleum Congress.

Carroll, A. R. and Bohacs, K. M. (1999). Stratigraphic classification of ancient lakes: balancing tectonic and climatic controls. Geology, 27, 99-102.

Cazier, E. C., C. Bargas, L. Buambua, S. Cardosa, H. Ferreira, A. Lopez, T. Nicholson, C. Olson, A. Saller, and J. Shinol (2014). Petroleum geology of Cameia field, deepwater Pre-Salt Kwanza Basin,Angola, West Africa: AAPG Search and Discovery article 20275.

Chafetz, H. S., and Buczynski, C. (1992). Bacterially induced lithification of microbial mats. Palaios, 7 (3), 277-293.

Chafetz, H. S., and Guidry, S. A. (1999). Bacterial shrubs, crystal shrubs, and ray-crystal shrubs: bacterial vs. abiotic precipitation. Sedimentary Geology, 126(1), 57-74.

Clarkson, E. N. K., Milner, A. R., and Coates, M. I. (1993). Palaeoecology of the Viséan of East Kirkton, West Lothian, Scotland. Transactions of the Royal Society of Edinburgh: Earth Sciences, 84, 417-425.

Davies, G. R. (1977). Former magnesian calcite and aragonite submarine cements in upper Paleozoic reefs of the Canadian Aretic: a summary. Geology, 5, 11-15.

Decho, A. W. (2010). Overview of biopolymer-induced mineralization: what goes on in 885 biofilms?. Ecological Engineering, 36,137-144.

Deocampo, D. M., and Renaut, R. W. (2016). Geochemistry of African Soda Lakes. In: Soda Lakes of East Africa (pp. 77-93). Springer International Publishing.

Dittrich, M. and Obst, M. (2004). Are picoplankton responsible for calcite precipitation in lakes? Ambio, 33, 559-564.

Driscoll, C. T. and Newton, R. M. (1985). Chemical characteristic of Adirondack lakes: individual lakes respond differently to acid deposition. Environmental Science Technology, 19, 1018-1024. 
Dunbar, G. B., and Dickens, G. R. (2003). Late Quaternary shedding of shallow-marine earbenate along a tropical mixed siliciclastic carbonate shelf: Great Barrier Reef, Australia. Sedimentology, 50, 1061-1077.

Dupraz, C., Reid, R. P., Braissant, O., Decho, A. W., Norman, R. S., and Visscher, P. T. (2009). Processes of carbonate precipitation in modern microbial mats. Earth-Science Reviews, 96, 141-162.

\section{Durant, G.P. (1994). Voleanogenic sediments of the East Kirkton Limestone (Viséan) of} West Lothian, Scotland. Transactions of the Royal Society of Edinburgh: Earth Sciences, 84, 203207.

Embry, A. F., and Johannessen, E. P. (1993). T-R sequence stratigraphy, facies analysis and reservoir distribution in the uppermost Triassic-Lower Jurassic succession, Western Sverdrup Basin, Arctic Canada. Arctic Geology and Petroleum Potential, 2, 121 146.

Ercole, C., Cacchio, P., Botta, A. L., Centi, V., and Lepidi, A. (2007). Bacterially induced mineralization of calcium carbonate: the role of exopolysaccharides and capsular polysaccharides. Microscopy and Microanalysis, 13, 42-50.

Flugel, E. (2004). Microfacies of carbonate rocks: analysis, interpretation and application. Springer.

Folk, R. L. (1965). Some aspects of recrystallization in ancient limestones. In: Dolomitization and limestone diagenesis (Eds. L. C. Pray). Society of Economic Paleontologists and Mineralogists, Special Publication 13, 14-48.

Freytet, P., and Verrecchia, E. (1993). Complex calcitic crystallizations in nostoc parmelioides kütz (Freshwater cyanobacterium): Rhombs around trichomes inside nostoc colonies and epiphytic bacterial microstromatolites. Geomicrobiology Journal, 11, 77-84. 
Freytet, P., Toutin-Morin, N., Broutin, J., Debriette, P., Durand, M., El Wartiti, M., and Sarfati, J. (1999). Palaeoecology of non-marine algae and stromatolites: Permian of France and adjacent countries. Annales de Paléontologie 85, 99-153.

Galat, D. L., Verdin, J. P. and Sims, L. L. (1990). Large-scale patterns of Nodularia spumigena blooms in Pyramid Lake, Nevada, determined from Landsat imagery: 19721986. Hydrobiologia, 197, 147-164.

García-Ruiz, J. M. (2000). Geochemical scenarios for the precipitation of biomimetic inorganic carbonates. In: Carbonate sedimentation and diagenesis in the evolving Precambrian world (Eds. J. Grotzinger and N. James). SEPM Special Publications, 67, 75-89.

Gierlowski-Kordesch, E. H. (2010). Lacustrine carbonates. Developments in Sedimentology, 61, 1-101.

Ginsburg, R. N., and James, N. P. (1976). Submarine botryoidal aragonite in Holocene reef limestones, Belize. Geology 4, 431-436.

González-Muñoz, M. T., Chekroun, K. B., Aboud, A. B., Arias, J. M., and RodríguezGallego, M. (2000). Bacterially induced Mg-calcite formation: role of $\mathrm{Mg}^{2+}$ in development of crystal morphology. Journal of Sedimentary Research, 70, 559-564.

Goodacre, I. R. (1999). Microbial carbonates in lacustrine settings: an investigation into the Carboniferous East Kirkton Limestone. Doctoral dissertation, University of Aberdeen.

Gradstein, F. M., Ogg, J. G. and Hilgen, F. J. (2012). On the geological time scale. Newsletter Stratigraphy, 45, 171-188.

Grant, W. D. and Jones, B. E. (2000). Alkaline environments. In: Encyclopedia of Microbiology, volume 1 (Ed. J. Lederberg). Academic Press. 
Greensmith, J. T. (1968). Palaeogeography and rhythmic deposition in the Scottish OilShale Group. In: United Nations Symposium on the Development and Utilization of Oil Shale Resources, Section B (pp. 1-16).

Guardado, L. R., Spadini, A. R., Brandão, J. S. L., and Mello, M. R. (2000). Petroleum System of the Campos Basin, Brazil. AAPG Memoir 73, Chapter 22.

Guido, D.M., Campbell, K.A. (2011). Jurassic hot spring deposits of the Deseado Massif (Patagonia, Argentina): Characteristics and controls on regional distribution. Journal of Volcanology and Geothermal Research 203, 35-47.

Herlinger, R. (2016). Controles deposicionais e diagenéticos das propriedades petrofísicas dos reservatórios Aptianos/Barremianos do grupo Lagoa Feia no norte da Bacia de Campos. MSc Dissertation. Universidad Federal do Rio Grande do Sul. Brazil. 124pp.

Hoagland, K. D., Rosowski, J. R., Gretz, M. R., and Roemer, S. C. (1993). Diatom extracellular polymeric substances: function, fine structure, chemistry, and physiology. Journal of Phycology, 29, 537-566.

Jones, B. E., Grant, W. D., Duckworth, W. and Owenson, G. G. (1998). Microbial diversity of soda lakes. Extremophiles, 2, 191-200.

Jones, B., and Renaut, R. W. (1995). Noncrystallographic calcite dendrites from hot-spring deposits at Lake Bogoria, Kenya. Journal of Sedimentary Research, 65, 154-169.

Kandianis, M. T., Fouke, B. W., Johnson, R. W., Veysey II, J. and Inskeep, W. P. (2008). Microbial biomass: a catalyst for $\mathrm{CaCO}_{3}$ precipitation in advection-dominated regimes. GSA Bulletin, 120, 442-450.

Kawaguchi, T., and Decho, A. W. (2000). Biochemical characterization of cyanobacterial extracellular polymers (EPS) from modern marine stromatolites (Bahamas). Preparative Biochemistry and Biotechnology, 30, 321-330. 
Kaźmierezak, J., and Kempe, S. (1992). Recent cyanobacterial counterparts of Paleozoic

Wetheredella and related problematic fossils. Palaios, 7, 294-304.

Kebede, S., Travi, Y., Alemayehu, T. and Ayenew, T. (2005). Groundwater recharge,

circulation and geochemical evolution in the source region of the Blue Nile River, Ethiopia. Applied Geochemistry, 20, 1658-1676.

Kelts, K., and Hsï, K. J. (1978). Freshwater carbenate sedimentation. In: Lakes (Ed. A. Lerman). 295-323. Springer New York.

Kelts, K., and Talbot, M. (1990). Lacustrine carbonates as geochemical archives of environmental change and biotic/abiotic interactions. In: Large Lakes (Eds. M. M. Tilzer and C. Serruya). 288-315. Springer Berlin Heidelberg.

Kempe, S., Kazmierczak, J., Landmann, G., Konuk, T., Reimer, A., and Lipp, A. (1991). Largest known microbialites discovered in Lake Van, Turkey. Nature, 349, 605-608.

Littlewood, J. L., Shaw, S., Peacock, C. L., Bots, P., Trivedi, D., \& Burke, I. T. (2017). Mechanism of Enhanced Strontium Uptake into Calcite via an Amorphous Calcium Carbonate Crystallization Pathway. Crystal Growth \& Design, 17(3), 1214-1223.

Loftus, G.W.F. and Greensmith, J. T. (1988). The lacustrine Burdiehouse Limestone Formation — a key to the deposition of the Dinantian Oil Shales of Scotland. In: Lacustrine Petroleum Source Rocks. (Eds. A. J.Fleet, K. Kelts, M. R.Talbot). Geological Society of London, Special Publications, 40, 219-234.

Longman, M. W. (1980). Carbonate diagenetic textures from nearsurface diagenetic environments. AAPG Bulletin, 64, 461-487.

Loste, E., Wilson, R. M., Seshadri, R., and Meldrum, F. C. (2003). The role of magnesium in stabilising amorphous calcium carbonate and controlling calcite morphologies. Journal of Crystal Growth, 254(1), 206-218. 
Lowe, D. R. (1979). Sediment gravity flows: their classification and some problems of application to natural flows and deposits. In: Geology of Continental Slopes (Eds. L. J. Doyle and O. H. Pilkey). SEPM Special Publications, 27, 75-82.

Luiz--Dias, J. (1998). Análise sedimentológica e estratigráfica do Andar aptiano em parte da margem leste do Brasil e no platô das Malvinas: considerações sobre as primeiras incursões e ingressões marinhas do oceano Atlântico Sul Meridional. Doctoral dissertation. Universidade Federal do Rio Grande do Sul. 1-411.

Mazzullo, S. J. (1980). Calcite pseudospar replacive of marine acicular aragonite, and implications for aragonite cement diagenesis. Journal of Sedimentary Research, 50, 409422.

McGill, R. A. R. (1994). Geochemistry and petrography of a Lower Carboniferous, lacustrine, hot spring deposit: East Kirkton, Bathgate, Scotland. Doctoral dissertation, University of Glasgow.

Melack, J. M. (1981). Photosynthetic activity of phytoplankton in tropical African soda lakes. Hydrobiologia, 81, 71-85.

Mercedes-Martín, R., Rogerson, M. R., Brasier, A. T., Vonhof, H. B., Prior, T., J., Fellows., S. M., Reijmer, J.J.G., Billing, I., and Pedley, H. M., (2016). Growing spherulitic calcite grains in saline, hyperalkaline lakes: experimental evaluation of the effects of Mg-clays and organic acids. Sedimentary Geology, 335, 93-102.

Merz, M. U. (1992). The biology of carbonate precipitation by cyanobacteria. Facies, 26, 81101.

Moreira, J. L. B., C.V. Madeira, J.A., Gil, and M.A. P.Machado (2007). Bacia de Campos (carta estratigráfica). Boletim de Geociencias da Petrobras, 14, 2, 531-549. 
Morrow, D. W. (1982). Descriptive Field Classification of Sedimentary and Diagenetic Breccia Fabries in Carbonate Rocks: GEOLOGICAL NOTE. Bulletin of Canadian Petroleum Geology, 30, 227-229.

Muir, R. D. and Walton, E. K. (1957). The East Kirkton Limestone. Transactions of the Geological Society of Glasgow, 22, 157-168.

Narcisi, B. (2001). Palaeoenvironmental and palaeoclimatic implications of the LateQuaternary sediment record of Vico volcanic lake (central Italy). Journal of Quaternary Science, 16 (3), 245-255.

Page, M. C. and Dickens, G. R. (2005). Sediment fluxes to Marion Plateau (southern Great Barrier Reef province) over the last $130 \mathrm{ky}$ : New constraints on 'transgressiveshedding'off northeastern Australia. Marine geology, 219, 27-45.

Parnell, J. (1988). Lacustrine petroleum source rocks in the Dinantian Oil Shale Group, Scotland: a review. In: Lacustrine Petroleum Source Rocks. (Eds. A. J.Fleet, K. Kelts, M. R.Talbot). Geological Society of London, Special Publications, 40, 235-246.

Passow, U. (2002). Production of transparent exopolymer particles (TEP) by phyto-and bacterioplankton. Marine ecology-progress series, 236, 1-12.

Passow, U., Shipe, R. F., Murray, A., Pak, D. K., Brzezinski, M. A. and Alldredge, A. L. (2001). The origin of transparent exopolymer particles (TEP) and their role in the sedimentation of particulate matter. Continental Shelf Research, 21, 327-346.

Pecoraino, G., D'Alessandro and W., Salvatore, I. (2015). The other side of the coin: geochemistry of alkaline lakes in volcanic areas. In: Volcanic Lakes, Advances in Volcanology (Eds. D. Rouwet, B. Christenson, F. Tassi and J. Vandemeulebrouck) IAVCEI. 219-237. Springer.

Pedley, M. (1992). Freshwater (phytoherm) reefs: the role of biofilms and their bearing on marine reef cementation. Sedimentary Geology, 79, 255-274. 
Pedley, M., Rogerson, M. and Middleton, R. (2009). Freshwater calcite precipitates from in vitro mesocosm flume experiments: a case for biomediation of tufas. Sedimentology, $\mathbf{5 6}$, $511-527$.

Platt, N. H. and Wright, V.P. (1991). Lacustrine carbonates: facies models, facies distributions and hydrocarbon aspects. In: Lacustrine Facies Analysis (Eds. P. Anadon, L1. Cabrera and K. Kelts). SEPM Special Publication, 13, 57.74.

Pueyo, J. J., Saez, A., Giralt, S., Valero-Garces, B. L., Moreno, A., Bao, R., Schwalb, A., Herrera, C., Klosowska, B. and Taberner, C. (2011). Carbonate and organic matter sedimentation and isotopic signatures in Lake Chungará, Chilean Altiplano, during the last 12.3 kyr. Palaeogeography, Palaeoclimatology, Palaeoecology, 307, 339-355.

Radke, L. C., Howard, K. W. F., and Gell, P. A. (2002). Chemical diversity in southeastern Australian saline lakes. I: geochemical causes. Marine and Freshwater Research, 53, 941-959.

Raymond, A. C. (1991). Carboniferous rocks of the Eastern and Central Midland Valley of Scotland: organic petrology, organic geochemistry and effects of igneous activity. Doctoral dissertation, University of Newcastle upon Tyne.

$\underline{\text { Raz, S., Weiner, S., \& Addadi, L. (2000). Formation of high-magnesian calcites via an }}$ amorphous precursor phase: possible biological implications. Advanced Materials, 12(1), 38-42.

Read, W.A., Browne, M.A.E., Stephenson, D., and Upton, B.J.G. (2002). Carboniferous. In: The Geology of Scotland, 4th. (Eds. N. H. Trewin). Geological Society, London, 251300. 
6

Renaut, R.W., Jones, B. (1997). Controls on aragonite and calcite precipitation in hot spring travertines at Chemurkeu, Lake Bogoria, Kenya. Canadian Journal of Earth Sciences, 34, 801-818.

Reuss, J. O., Cosby, B. J. and Wright, R. F. (1987). Chemical processes governing soil and water acidification. Nature, 329, 27-32

Rezende, M. F. and Pope, M. C. (2015). Importance of depositional texture in pore characterization of subsalt microbialite carbonates, offshore Brazil. In: Microbial Carbonates in Space and Time: Implications for Global Exploration and Production. (Eds. D. W. J. Bosence, K. A. Gibbons, D. P. Le Heron, W. A. Morgan, T. Pritchard, and B. A. Vining). Geological Society of London, Special Publications, 418, 193-207.

Rippon, J., Read, W. A., and Park, R. G. (1996). The Ochil Fault and the Kincardine basin: key structures in the tectonic evolution of the Midland Valley of Scotland. Journal of the Geological Society, 153(4), 573-587.

Rodriguez-Blanco, J. D., Shaw, S., Bots, P., Roncal-Herrero, T., and Benning, L. G. (2012). The role of $\mathrm{pH}$ and $\mathrm{Mg}$ on the stability and crystallization of amorphous calcium carbonate. Journal of Alloys and Compounds, 536, S477-S479.

Rodríguez-Navarro, C., Jiménez-Lopez, C., Rodríguez-Navarro, A., González-Muñoz, M. T., and Rodríguez-Gallego, M. (2007). Bacterially mediated mineralization of vaterite. Geochimica et Cosmochimica Acta, 71, 1197-1213.

Rogerson, M., Mercedes-Martín, R., Brasier, A. T., McGill, R. A., Prior, T. J., Vonhof, H., Fellows, S., Reijmer, J. J. G., McClymont, E., Billing, I., Matthews, A and Pedley, M. (2017). Are spherulitic lacustrine carbonates an expression of large-scale mineral carbonation? A case study from the East Kirkton Limestone, Scotland. Gondwana Research. https://doi.org/10.1016/j.gr.2017.04.007. 
Rolfe, W. D. I. , Durant, G. P, Baird, W. J., Chaplin, C, Paton, R. L., and Reekie, R. J. (1993). The East Kirkton Limestone, Viséan, of West Lothian, Scotland: introduction and stratigraphy. Transactions of the Royal Society of Edinburgh: Earth Sciences, 84, 177-188.

Romero, J. R. and Melack, J. M. (1996). Sensitivity of vertical mixing in a large saline lake to variations in runoff. Limnology and Oceanography, 41, 955-965.

Rowe, G. L. and Brantley, S. L. (1993). Estimation of the dissolution rates of andesitic glass, plagioclase and pyroxene in a flank aquifer of Poas Volcano, Costa Rica. Chemical Geology, 105, 71-87.

Ruta, M. and Clack, J. A. (2006). A review of Silvanerpeton miripedes, a stem amniote from the Lower Carboniferous of East Kirkton, West Lothian, Scotland. Transactions of the Royal Society of Edinburgh: Earth Sciences, 97, 31-63.

Sánchez-Navas, A., Martín-Algarra, A., Rivadeneyra, M. A., Melchor, S. and MartínRamos, J. D. (2009). Crystal-Growth Behavior in $\mathrm{Ca}-\mathrm{Mg}$ Carbonate Bacterial Spherulites. Crystal Growth and Design, 9, 2690-2699.

Schneider, J. and Le Campion-Alsumard, T. (1999). Construction and destruction of carbonates by marine and freshwater cyanobacteria. European Journal of Phycology, 34, 417-426.

Schroeder, J. H. (1972). Fabrics and sequences of submarine carbonate cements in Holocene Bermuda cup reefs. Geologische Rundschau, 61, 708-730.

Scott, A. C., Brown, R., Galtier, J., and Meyer-Berthaud, B. (1993). Fossil plants from the Viséan of East Kirkton, West Lothian, Scotland. Transactions of the Royal Society of Edinburgh: Earth Sciences, 84, 249-260.

Smithson, T. R. (1989). The earliest known reptile. Nature, 342, 676-678. 
Spadafora, A., Peri, E., McKenzie, J. A. and Vasconcelos, C. (2010). Microbial

biomineralization processes forming modern $\mathrm{Ca}: \mathrm{Mg}$ carbonate stromatolites. Sedimentology, 57, 27-40.

Spence, G.H., and Tucker, M.E. (2007). A proposed integrated multi-signature model for peritidal cycles in carbonates. Journal of Sedimentary Research, 77(10), 797808.

Stabel, H. H. (1986). Calcite precipitation in Lake Constance: chemical equilibrium, sedimentation, and nucleation by algae. Limnology and Oceanography, 31, 1081-1094.

Stockner, J., Callieri, C. and Cronberg, G. (2000). Picoplankton and other non-bloomforming cyanobacteria in lakes. In: The ecology of cyanobacteria. (Eds. B. A. Whitton and M. Potts). Kluwer Academic Publishers, 195-231

Strachan, L. J., and Alsop, G. I. (2006). Slump folds as estimators of palaeoslope: a case study from the Fisherstreet Slump of County Clare, Ireland. Basin Research, 18, 451-470.

Terra G. J. S., Terra, G.J.S., Spadini, A.R., França, A.B., Sombra, C.L., Zambonato, E.E., Juschaks, L.C.d.S., Arienti, L.M., Erthal, M.M., Blauth, M., Franco, P.P., Matsuda, N.S., da Silva, N.G.C., Junior, P.A.M., D’Avila, R.S.F., deSouza, R.S., Tonietto, S.N., dos Anjos, S.M.C., Campinho, V.S. and Winter, W.R. (2010). Classificação de rochas carbonáticas aplicável às bacias sedimentares brasileiras. Bulletin Geoscience Petrobras, Rio de Janeiro, 18, 9-29.

Tosca, N. J. and Wright, V. P. (2015). Diagenetic pathways linked to labile Mg-clays in lacustrine carbonate reservoirs: a model for the origin of secondary porosity in the Cretaceous Pre-Salt Barra Velha Formation, offshore Brazil. In: Reservoir quality of clastic and carbonate rocks: analysis, modelling and prediction. (Eds. P. J. Armitage, A. R., Butcher, J. M. Churchill, A. E. Csoma, C. Hollis, R. H. Lander, J. E. Omma, and R. H. Worden). Geological Society, London, Special Publications, 435, SP435-1. 
Trichet, J. and Défarge, C. (1995). Non-biologically supported organobiomineralization. Bulletin de l'Institut Océanographique, 14, 203-236.

Verrecchia, E. P, Freytet. P., Verrecchia, K. E. and Dumont, J-L. (1995). Spherulites in calcrete laminar crusts: biogenic $\mathrm{Ca} \mathrm{CO}_{3}$ precipitation as a major contributor to crust formation. Journal of Sedimentary Research, 65, 690-700

Walkden, G. M., Roddy Irwin, J. and Fallick, A. E. (1993). Carbonate spherules and botryoids as lake floor cements in the East Kirkton Limestone of West Lothian, Scotland. Transactions of the Royal Society of Edinburgh: Earth Sciences, 84, 213-221.

Wanas, H. A. (2012). Pseudospherulitic fibrous calcite from the Quaternary shallow lacustrine carbonates of the Farafra Oasis, Western Desert, Egypt: A primary precipitate with possible bacterial influence. Journal of African Earth Sciences, 65, 105-114.

Wang, D., Hamm, L. M., Giuffre, A. J., Echigo, T., Rimstidt, J. D., De Yoreo, J.

Grotzinger, J. \& Dove, P. M. (2012). Revisiting geochemical controls on patterns of carbonate deposition through the lens of multiple pathways to mineralization. Faraday Discussions, 159(1), 371-386.

Whyte, M. A. (1993). Scottish Carboniferous fresh-water limestones in their regional setting. Transactions of the Royal Society of Edinburgh: Earth Sciences, 84(3-4), 239-248.

Wolthers, M., Nehrke, G., and Fokkema, M. (2008). Coupled Effects of Aspartic Acid and Magnesium on Biocalcification. Geophysical Research Abstracts, 10, EGU General Assembly.

Wood, S. P., Panchen, A. L. and Smithson, T. R. (1985). A terrestrial fauna from the Scottish Lower Carboniferous. Nature 314, 355-356

Woodcock, N. H. (1979). The use of slump structures as palaeoslope orientation estimators. Sedimentology, 26, 83-99. 
Wright, V.P. (2012). Lacustrine carbonates in rift settings: the interaction of voleanic and microbial processes on carbonate deposition. In: Advances in carbonate exploration and reservoir analysis. (Eds. J. Garland, L. E. Neilson, S. E., Laubach, and K. J. Whidden). Geological Society, London, Special Publications 2012, 370, 39-47.

Wright, V. P., and Barnett, A. J. (2015). An abiotic model for the development of textures in some South Atlantic early Cretaceous lacustrine carbonates. In: Microbial Carbonates in Space and Time: Implications for Global Exploration and Production. (Eds. D. W. J. Bosence, K. A, Gibbons, D. P. le Heron, W.A. Morgan, T. Pritchard and B. A. Vining). Geological Society, London, Special Publications 418, 209-219.

\section{FIGURE CAPTIONS}

FIGURE 1. Litho- and chronostratigraphical divisions of the Carboniferous in the Midland Valley of Scotland. The East Kirkton Limestone area is located in the red square. Modified from Read et al., (2002). Ages from Gradstein et al., (2012).

FIGURE 2. A) The Midland Valley isopachs during Strathclyde Group deposition_(modified from

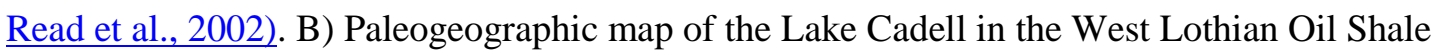
Formation(Bathgate Group). Extensive volcanic piles divided the Midland Valley into a series of semi-enclosed lacustrine-lagoonal basins (modified from Parnell, 1988). Marine incursions were intermittent. C) Geological map of the East Kirkton Limestone area, modified from Cameron et al., (1998).

FIGURE 3. The East Kirkton Limestone Quarry area. A) Photomosaic of the studied quarry and location of boreholes BH-1, BH-2 and BH-3, and logs EK-1 and EK-2 (inset) (reprinted from McGill, 1994).Person for scale. B) Detail of mMetric-scale slumped beds inclined towards the WNW. C) 
1182

1

21183

3

41184

5

6

$7^{1185}$

8

91186

10

111187

12

131188

14

15

16

17

Detail of B showing distorted slumped Facies 1laminites. D) Internal soft-sediment deformation within a flat-bounded bed.

FIGURE 4. Laminites. A) Left: Flat tabular beds in outcropshowing millimetre thick alternation of earbenate-rich layers with organic-rich layers. Right: B)-Internal structure shows tThicker yellowish carbonate laminae $[\mathrm{C}]$ alternating with thinner darker organic laminae $[\mathrm{O}]$ or milky-silica laminae [Si] in eross $\underline{X}$-Nichols. $\underline{B})$ Composite image of alternating organic laminae $[\mathrm{O}]$ with primary silica laminae [Si] seen vitreous in X-Nichols (left) and milky in plane light (right). Cracks in silica laminae are filled by calcite (arrow). C) BSE image of pyrite framboids al aggregates-(EDX pattern, bottom leftinset)-embedded in carbonate or organic laminae. D) Spherulitic laminites eontain-with Spherulitic Coated Grains [SG] displayingisolated, loosely packed textures mainly-within organic laminae. E) Organic laminae pinches out towards the edges of grains [arrows] displaying thickness variations across them. Carbonaceous/algal remains constitute the core of some grains (centre) (eross $\underline{X}$-Nichols image).

FIGURE 5. Spherulitic grainstone-packstone and Spherulitic cementstoneShrubby carbenate buildups. A) Laminated gGrainstone-packstone displaying a laminated fabric made ofwith spherulitic grains alternating with thin amorphous Mg-Si tayers-clays [arrow]. B) Đetail of-Moderately-sorted and well-rounded grainstone-packstone of well-sorted and well rounded-spherulitic grains embedded in an amorphous $\mathrm{Mg}$-Si matrix [arrow] locally replaced by blocky calcite, in eress $\underline{X}-$ Nichols. C) Dome-shaped-to lenticular spherulitic cementstone shrubby carbonate-build-ups (F3) tilted on top of slumped layers eomposed-made of laminites (F1), volcanic tuffs (F4) and shales (F6). Original

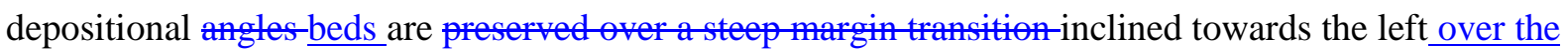
margin. D) An incised surface [dotted line] on top of laminites (F1) is filled by volcanic and intraclastic tuffs (F4), and overlaid by spherulitic cementstone shrubby carbenates-(F3). E) Detail on C showing laminites (F1) overlaid by tiny shrubby 'clotted' fabrics [arrow] giving risevertically evolving to to decimetre thick bodies of spherulitic cementstone shrubby carbonate-build-ups (F3). F) 
Polished slab of the spherulitic cementstone shrubby carbonate build-ups-displaying 'clotted'-clastsupported breccias with interelast voids-filled with silica cements [red arrow].

FIGURE 6. Volcanic and intraclastic calcareous tuffs, Intraclastic wackestone-floatstone layered earbenates-and s. Shales. A) Volcanic tuffs as they appear-in core (BH-2) and intraclastic calcareous tuffs (arrowed in BH-3). B) Volcanic tuff in thin section-showdisplaying a porphyritic texture with of phenocrysts floating in a cryptocrystalline glassy matrix. Plagioclase (Pg), Clinopyroxene (Cpx) and Olivine (Ol). C) Floatstone of spherulitic components (Spherulitic Coated Grains, (SG) in a red-brown $\mathrm{Mg}-\mathrm{Si}$ clay matrix [S]. Lapilli intraclasts [Lap] with-show vesicular textures-are observed. SerpentineClay like XRD pattern at the bottom (red spot). D) BSE image of a similar-floatstone with Spherulitic Coated Grains [SG], and lapilli fragments [Lap] embedded-in a Mg-Si matrix [S]. EDX analyses of amorphous $\mathrm{Mg}$-Si phases (now serpentine, red spots) and volcanic minerals (blue spots).

E) Intraclastic wackestone-floatstone Layered carbonates-alternating with dark- $\underline{S}$ shales in outcrop (left). Cores from $\mathrm{BH}-3$ Cores on the right displaying-showing laminites (F1) on top of shales (F6) and volcanic tuffs (F4) en the right (arrow peints-to base). F) Detail of E showing Intraclastic wackestonefloatstone the internal fabric of the layered carbenates. Wackestene floatstene of intraclastic-contorted carbonate laminae are floating in a muddy matrix.

FIGURE 7. A) Depositional architecture of a SㅌE-NNW transect in the East Kirkton Limestone Quarry including data from-logs (EK-1 and 2) and boreholes (BH-1, 2 and 3). Two large-scale cycles are identified (Cycle 1 and 2) and they are in turn-composed up to 5 small-scale cycles. Note that mMetre-thick basalt layers occur on top of borehole BH-1. B) Location of logs and boreholes-ever the Stereographic projection displaying slump fold polar axes grouped fairly parallel ene another and-to the inferred paleo-slope strike polar projection [blue asterisk].

FIGURE 8. Key symbols used in figures. Type section at East Kirkton succession (EK-1 and EK-2) integrating facies, small-scale cycles (SSC), large-scale cycles (LSC), sedimentary environment, lake level variations and distribution of spherulitic components. 
FIGURE 9. Spherulitic Coated Grains. A) Fibrous Calcite crystals [f] are bordering fanning out from the carbonaceous cores [c]. Pervasive corrosion and later Subhedral Silica [Ss] obliterated the fibrous terminations. B) Spherulitic Calcite fabric is made of fibro-radial polycrystals growing upon Fibrous Calcite, and producing spheroidal grains (Type 1) (eross $\underline{X}-N i c h o l s) . C)$ Botryoidal-Spherulitic Calcite eensist growing on top of elongated substrates produced botryoidal fan-shaped coatings en radially divergent polycrystals generating botryoidal fans, and producing non-spheroidal, elongated grains (Type 2 grains) in X-Nichols. Subhedral Silica [Ss] cementing decayed organic filaments as seen in a BSE image.Competition for growth space between fans is common. D) Spherulitic Calcite fans and Botryoidal Calcite exhibit show corrosion scars (dotted lines) which acting as nucleation surfaces $\theta f$ renewed generations offrom successive crystals (eress $\underline{X}$-Nichols). E) Detail of D showing resumed Botryoidat-Spherulitic Calcite-growth upon dissolution surfaces (dotted lines). Calcite growth directions shown in arrows (eress $\underline{X}$-Nichols). F) Spherulitic 'oncoids' are formed by concentric layers of crystals growing in optical and lattice continuity upon subtle previous surfaces (yellow arrows) (eross $\underline{X}$-Nichols). Deflection of ealeite-fibres in the edges (red arrow) and corrosion surfaces (dotted line) are presentcommon.

FIGURE 10. Spherulitic Coated Grains. A) Spherulitic Calcite crystals commonly deflect in later stages of growth [red arrows] (eress $\underline{X}$-Nichols). B) Detail of A showing crystal deflection of spherules [red arrow], and corrosion surfaces [yellow dotted line] overlaid by Botryoidal- $\underline{\text { Spherulitic }}$

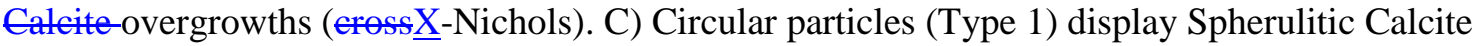
fabrics growing in a spheroidal fashion, whereas elongated particles (Type 2) display show Botryoidat Ealcite fabriesbotryoidal fan overgrowths. Note the carbonaceous core within the elongated coated grain (eross $\underline{X}$-Nichols). D) Elongated algae fragments (top) or ash remains (bottom) ean serve-as precursor nuclei. Fibrous Calcite fringes (f) and Subhedral Silica (Ss) are observed-eating coresseen in cores (eress $\underline{X}-$ Nichols). 
1264

1

21265

3

41266

5

6

$7^{1267}$

8

91268

10

111269

12

131270

14

15

16

17

FIGURE 11. Spherulitic Crusts. A) Spherulitic Crusts [SC] are buried by Mg-Si layers [S]. Note

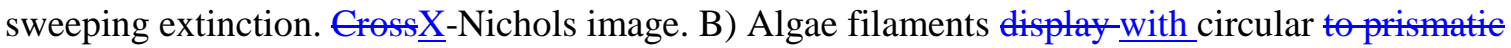

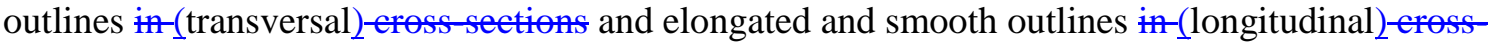
sections and-are embeddedtrapped within Spherulitic Calcite. C) Boundaries between discrete Spherulitic Calcite bundles are corroded and filled by Mg-Si minerals [arrows]. D) Cross $\underline{X}$-Nichols image of C displaying with overlapping of crusts showing with sweeping extinction. Mg-Si minerals are replaced by new generations ofnewer epitaxially grown spherulitic crusts-growing on top of older erusts. E) Algae inclusions-Moulds of decayed filaments within spherules can beare replaced filled by sparite (left) or filled with-Mg-Si minerals [S, arrow]. F) Spherulitic Crust enveloping fanning out

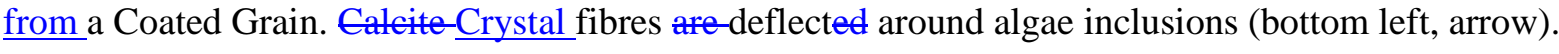

FIGURE 12. Spherulitic Intraclasts. A) Packstone of Type 1 Intraclasts formed by elongated $\underline{\text { Spherulitic BotryoidalCalcite objects cemented by blocky calcite (c). Cross } \underline{X}-N i c h o l s ~ i m a g e . ~ B) ~}$ Tubiform Type 2 Intraclasts made of laterally linked Spherulitic BotryoidatCalcite. Tubes are filled by peloids (Pel) and buried by $\mathrm{Mg}$-Si matrices-clays (S) eften-replaced by calcite pseudemerphs-after dissolution (top). C) Panoramic view of a tubiform Type 2 Intraclast (outlined in dotted line) filled with Spherulitic Crusts [SC]. D) Surface of a-Spherulitic Intraclast corroded and filled with a

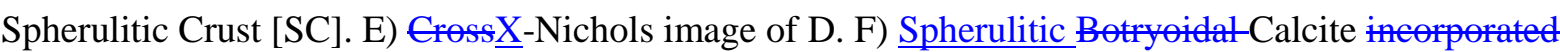
encapsulating filamentous algae. Deflection of calcite fibres is observed on top of the filament.

FIGURE 13. Stacked Fans. A) Laterally and vertically-stacked shrubby 'clotted' forms. Dark patches are kerogeneus organic matter. Micro-seale b $b$ Brecciastion features_filled with silica cements are [arrows]. B) Scalloped dissolution pits [arrows]. C) Cross $\underline{X}$-Nichols image of B. Note sweeping extinction and thin and continuous silica taminae-rims outlining previous Stacked Fans [arrows]. D) Corroded Stacked Fans are successively

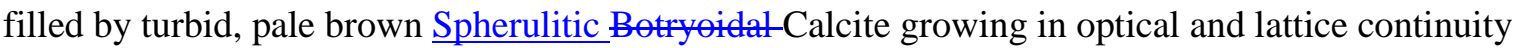
[arrows]. E) Chert filling corrosion cavities of individualfans. Cross $\underline{X}$-Nichols image. F) Detail in A. Interclast breccia voids (top) are filled with microcrystalline to fibro-radial/spherulitic 
silicachalcedony. Spherulitic BotryoidalCalcite fans (bottom) are stacked forming positive micro-

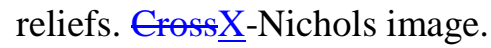

FIGURE 14. Formation of Spherulitic Coated Grains (top to bottom).

FIGURE 15. Formation of Spherulitic Crusts (top to bottom).

FIGURE 16. Formation of Spherulitic Intraclasts (top to bottom).

FIGURE 17. Formation of Stacked Fans (top to bottom).

FIGURE 18. Depositional model of the East Kirkton Limestone deposit, including sedimentary

features and the occurrence of processes, textures and small-scale cycles. Not to scale (See Fig. 8 for symbols).

TABLE 1. Summary of the facies types.

TABLE 2. Summary of the petrographic features of spherulitic components. 


\begin{tabular}{|c|c|c|c|c|c|c|c|c|}
\hline \multirow{2}{*}{ 응 } & \multirow{2}{*}{ Series } & \multirow{2}{*}{ Group } & \multicolumn{6}{|c|}{ Midland Valley } \\
\hline & & & \multicolumn{2}{|c|}{ Ayrshire \& Fife } & \multicolumn{4}{|c|}{ W Lothian } \\
\hline & \multirow{3}{*}{ 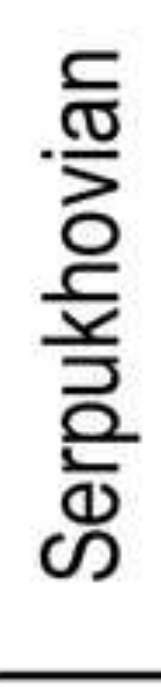 } & \multirow{4}{*}{ 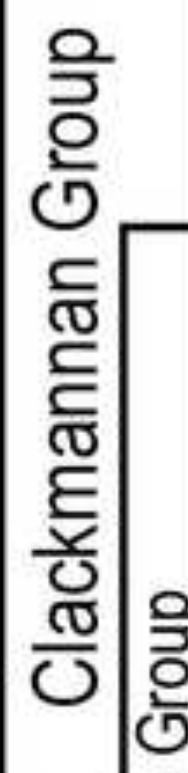 } & \multicolumn{6}{|c|}{ Passage Fm. mostly fluvial } \\
\hline & & & \multirow{2}{*}{\begin{tabular}{|l|} 
Upper \\
Limestone \\
Fm. \\
Limestone Coal \\
Fm.
\end{tabular}} & \multirow{4}{*}{ 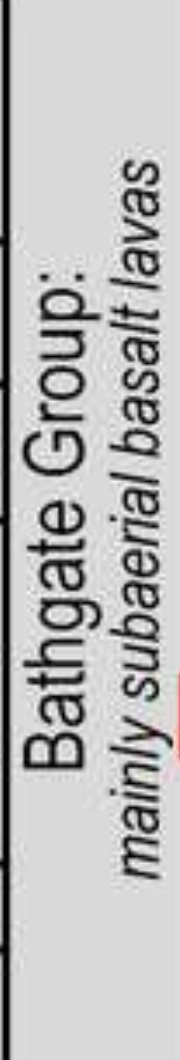 } & \multicolumn{4}{|c|}{$\begin{array}{l}\text { Major marine limestone \& } \\
\text { incised fluvial sandstones }\end{array}$} \\
\hline & & & & & \multicolumn{4}{|c|}{$\begin{array}{l}\text { Fluviodeltaic coal-bearing } \\
\text { cycles \& sandstones }\end{array}$} \\
\hline \multirow{3}{*}{ 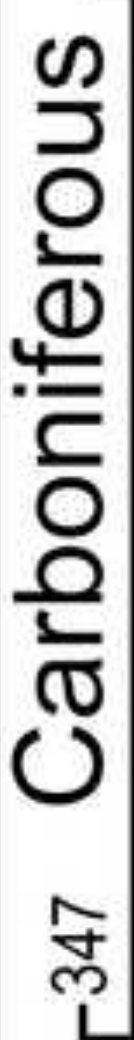 } & \multirow{3}{*}{$\begin{array}{l}\frac{C}{\mathbb{U}} \\
. \stackrel{\mathscr{N}}{>}\end{array}$} & & $\begin{array}{l}\text { Lower Limestone } \\
\text { Fm. }\end{array}$ & & \multicolumn{4}{|c|}{ Marine to fluviodeltaic } \\
\hline & & 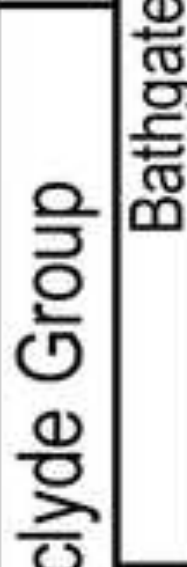 & $\begin{array}{l}\text { Lawmuir Fm. } \\
\text { Kirkwood } \\
\text { Clyde } \\
\text { Plateau } \\
\text { Volcanic }\end{array}$ & & \multicolumn{3}{|c|}{\begin{tabular}{l|}
$\begin{array}{l}\text { West Lothian } \\
\text { Oil-shale Fm. }\end{array}$ \\
$\begin{array}{l}\text { Fluvial \& } \\
\text { lacustrine: } \\
\text { oil-shales in deep, } \\
\text { stratified lakes }\end{array}$ \\
\end{tabular}} & \multirow[t]{2}{*}{ 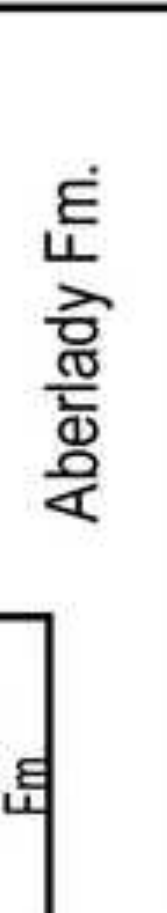 } \\
\hline & & 売 & $\begin{array}{l}\text { Fm. } \\
\text { Subaerial basalts } \\
\text { from vents \& } \\
\text { volcanoes }\end{array}$ & \multicolumn{4}{|c|}{ 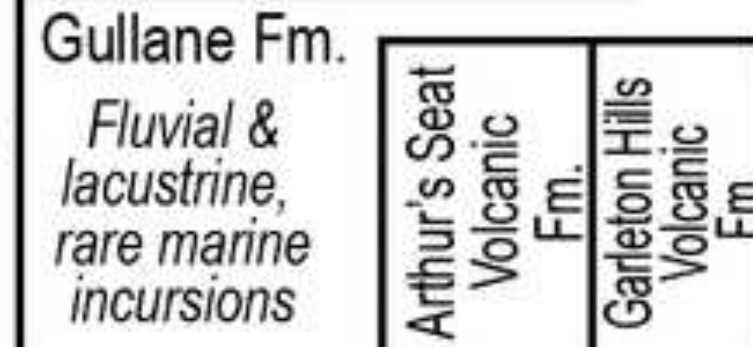 } & \\
\hline & \multirow{2}{*}{ 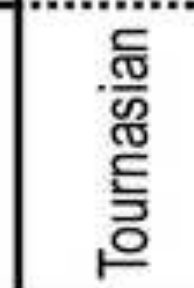 } & \multirow{2}{*}{ 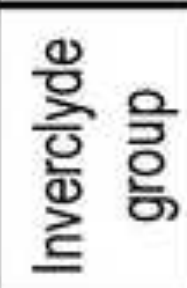 } & \multicolumn{6}{|c|}{$\begin{array}{r}\text { Clyde Sandstone Fm. } \\
\text { Ballagan Fm. }\end{array}$} \\
\hline & & & \multicolumn{6}{|c|}{ Kinnesswood Fm. } \\
\hline
\end{tabular}


Click here to download high resolution image

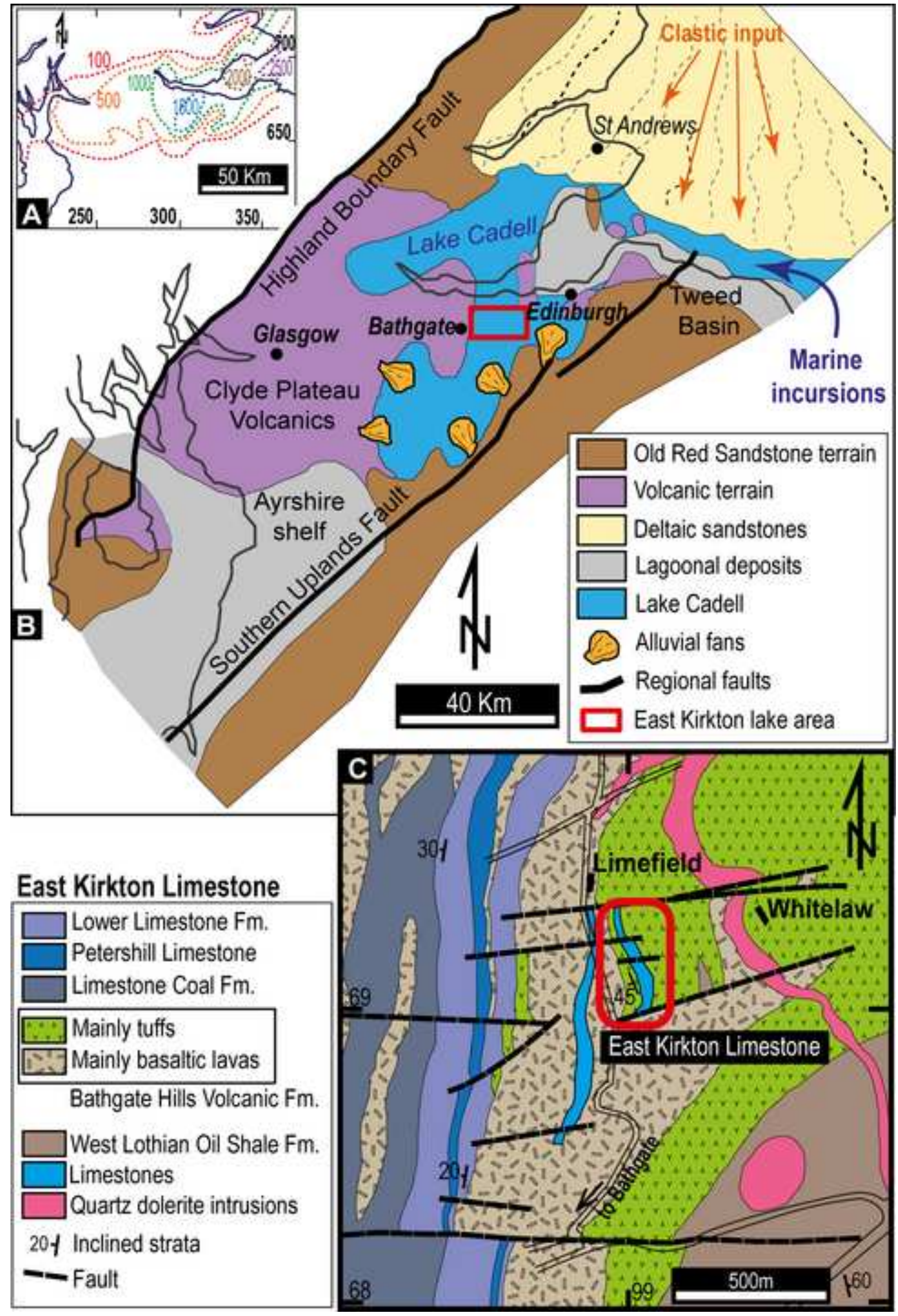


Click here to download high resolution image

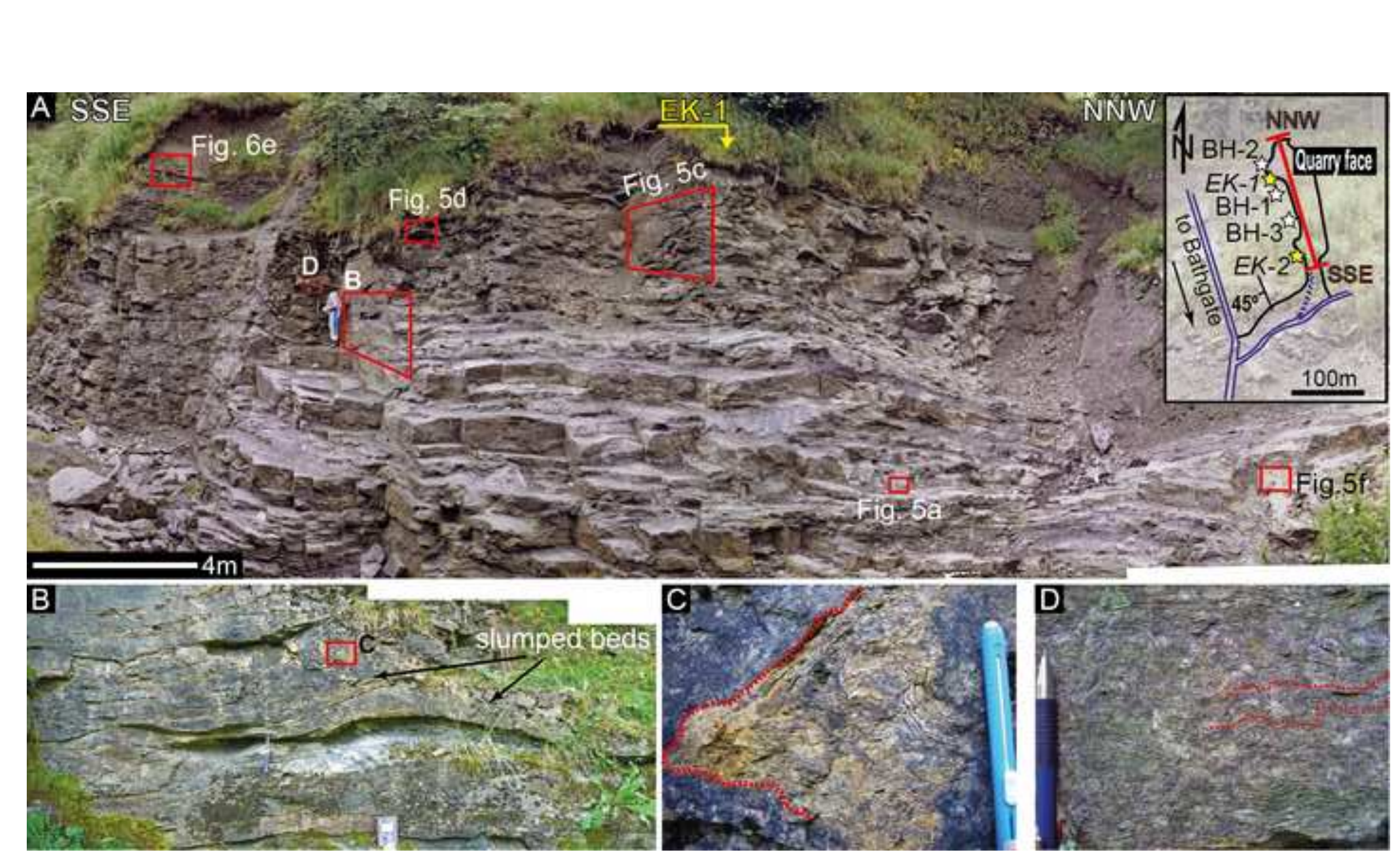

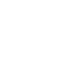

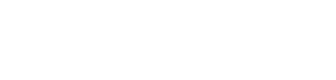

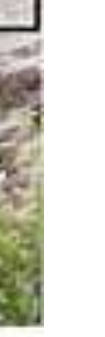
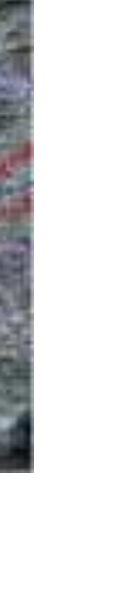

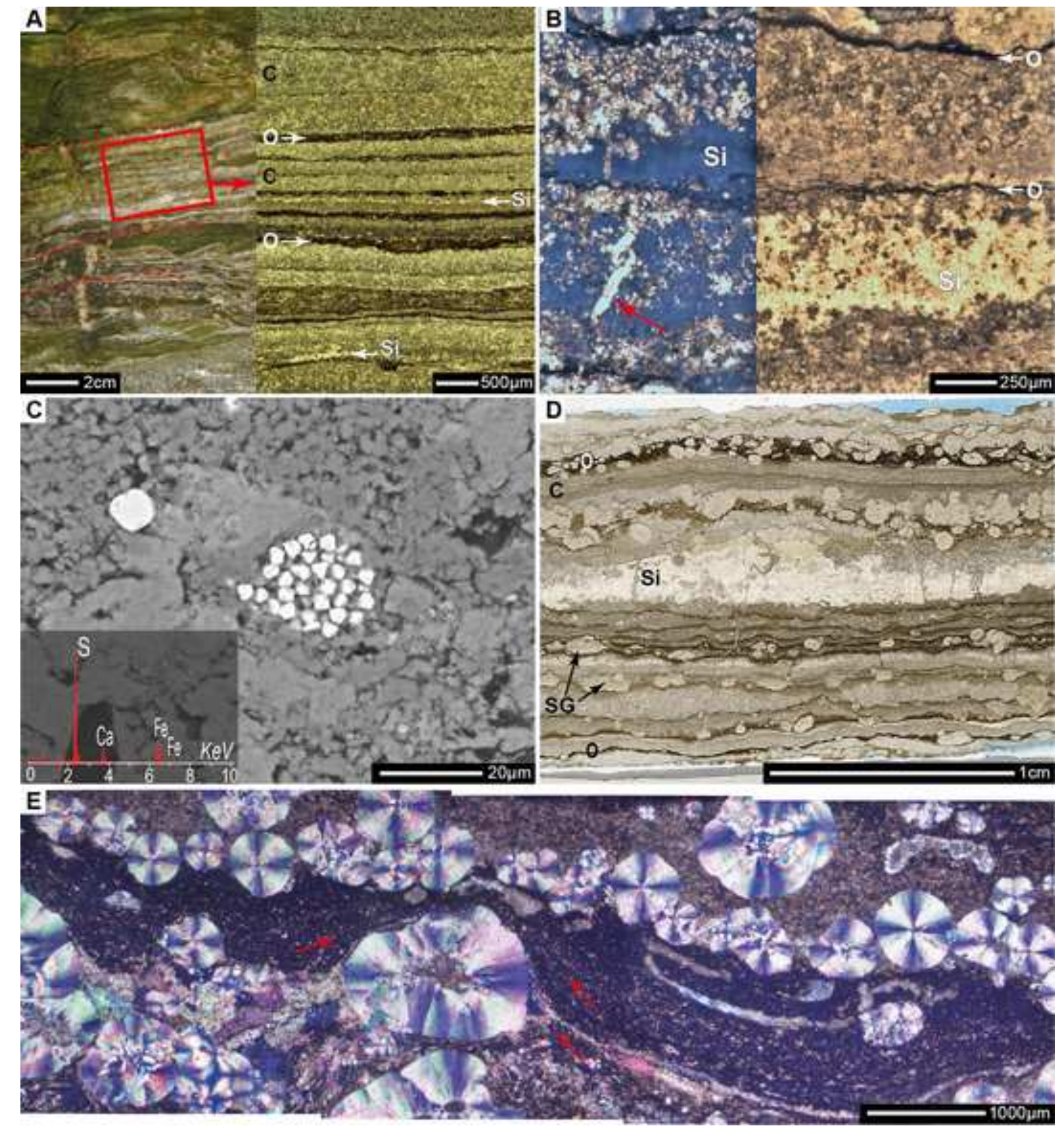

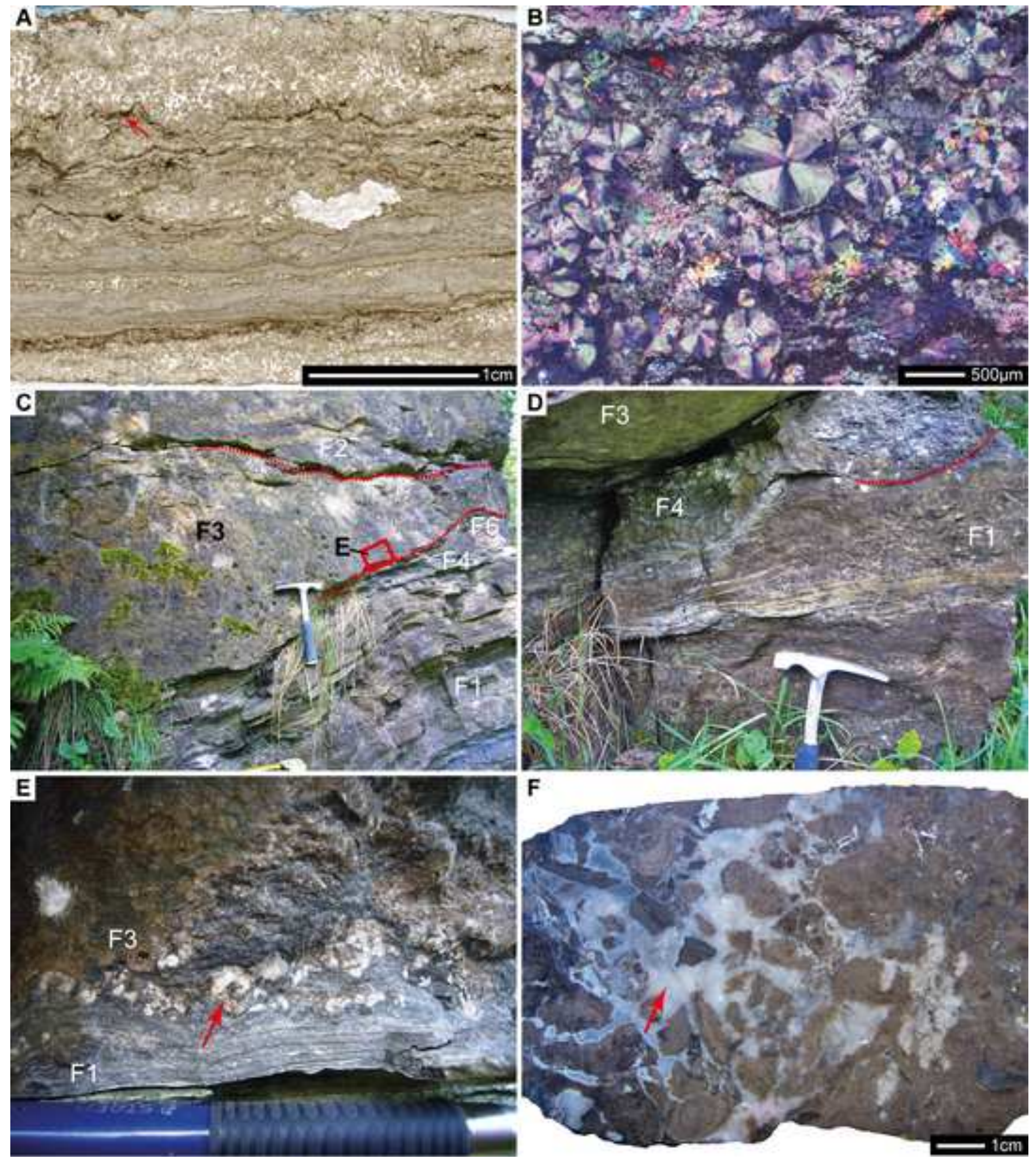

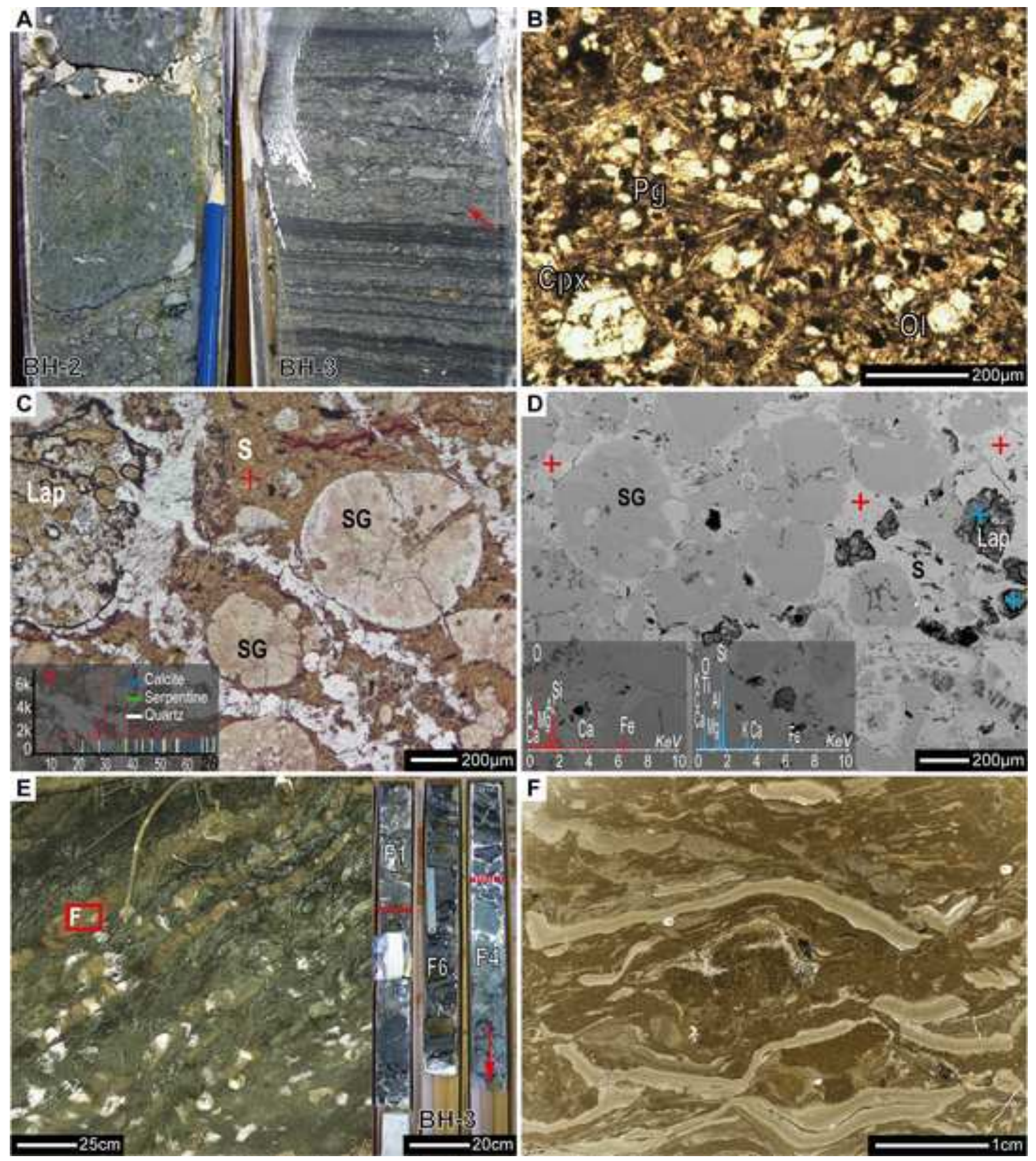
Click here to download high resolution image

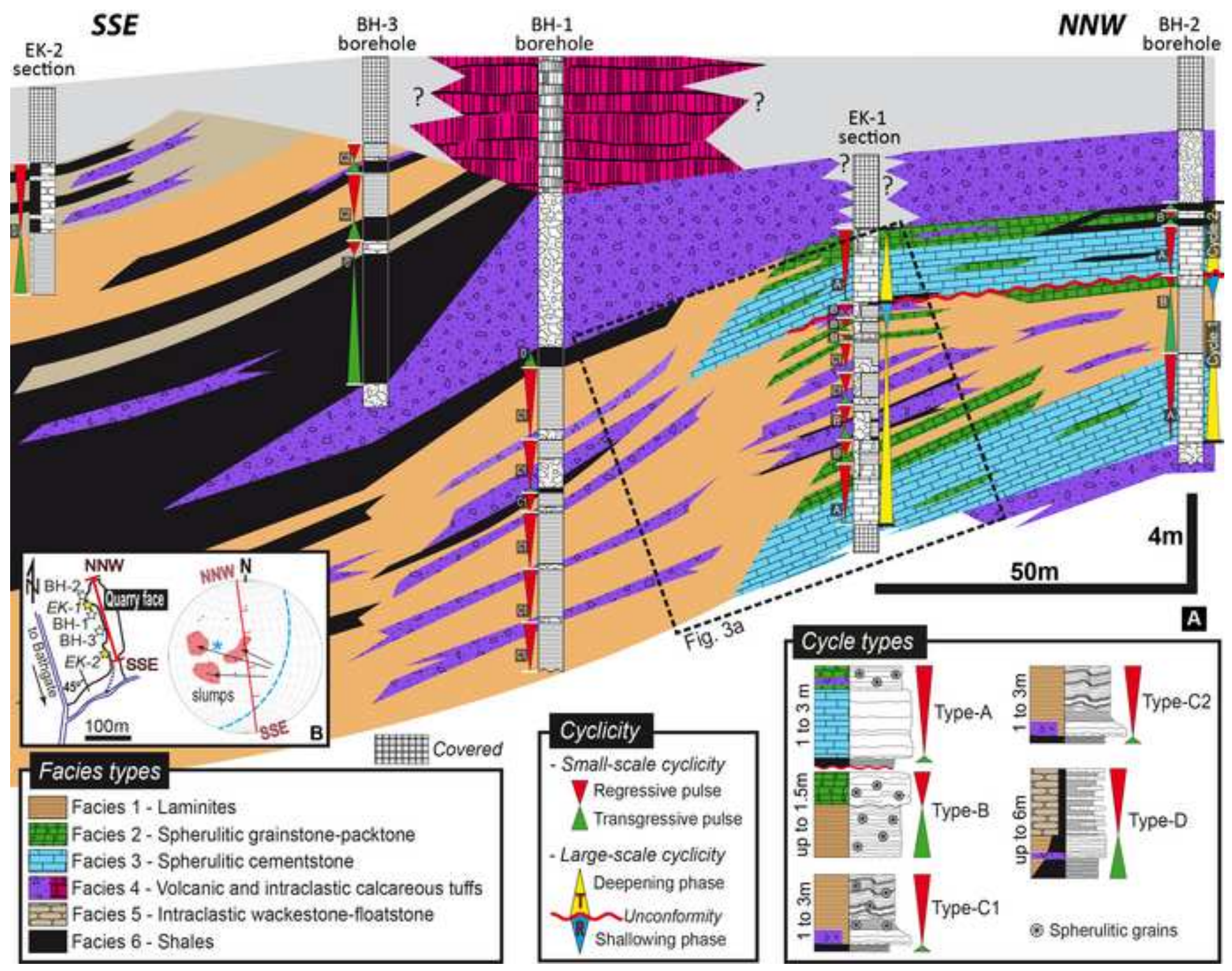




\section{Symbols used in Figures}

Sedimentary features and fossil content

$\approx$ Slumps

$\equiv$ Laminated fabrics

$=\approx$ Creeping and micro-sliding

$\theta_{\mathrm{Si}}$ Silica nodules

$\checkmark$ Ostracods (Carbonita)

$\theta$ Plant remains

4 Clotted fabrics

$\overleftrightarrow{S M W P G C}$ Shale, Mud-,Wacke-, Pack-,Grainstone Cementstone

Spherulitic components and related textures

${ }_{\text {w }}$ Stacked Fans

$\triangle$ Cavity-filling silica cements

* Coated Grains

(2) Oncoids

Crusts

d) Intraclasts

1) Algae/plants incrusted with Spherulitic Calcite

Distribution and abundance of components

\section{Allochthonous grains}

Autochthonous grains

0, 1, 2, 3 Scarce, Common, Abundant, Very abundant 
Figure $8 b$

Click here to download high resolution image

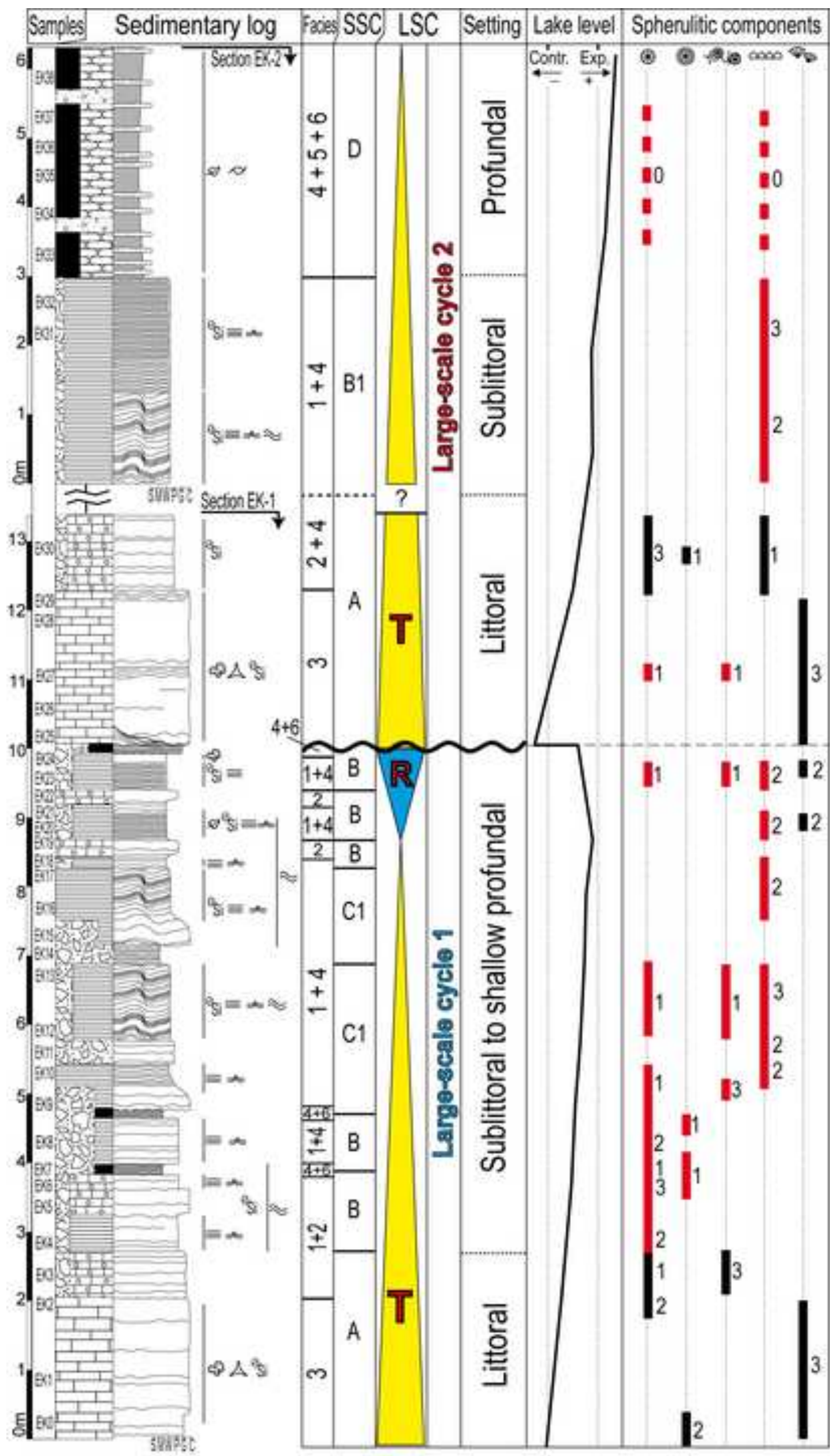



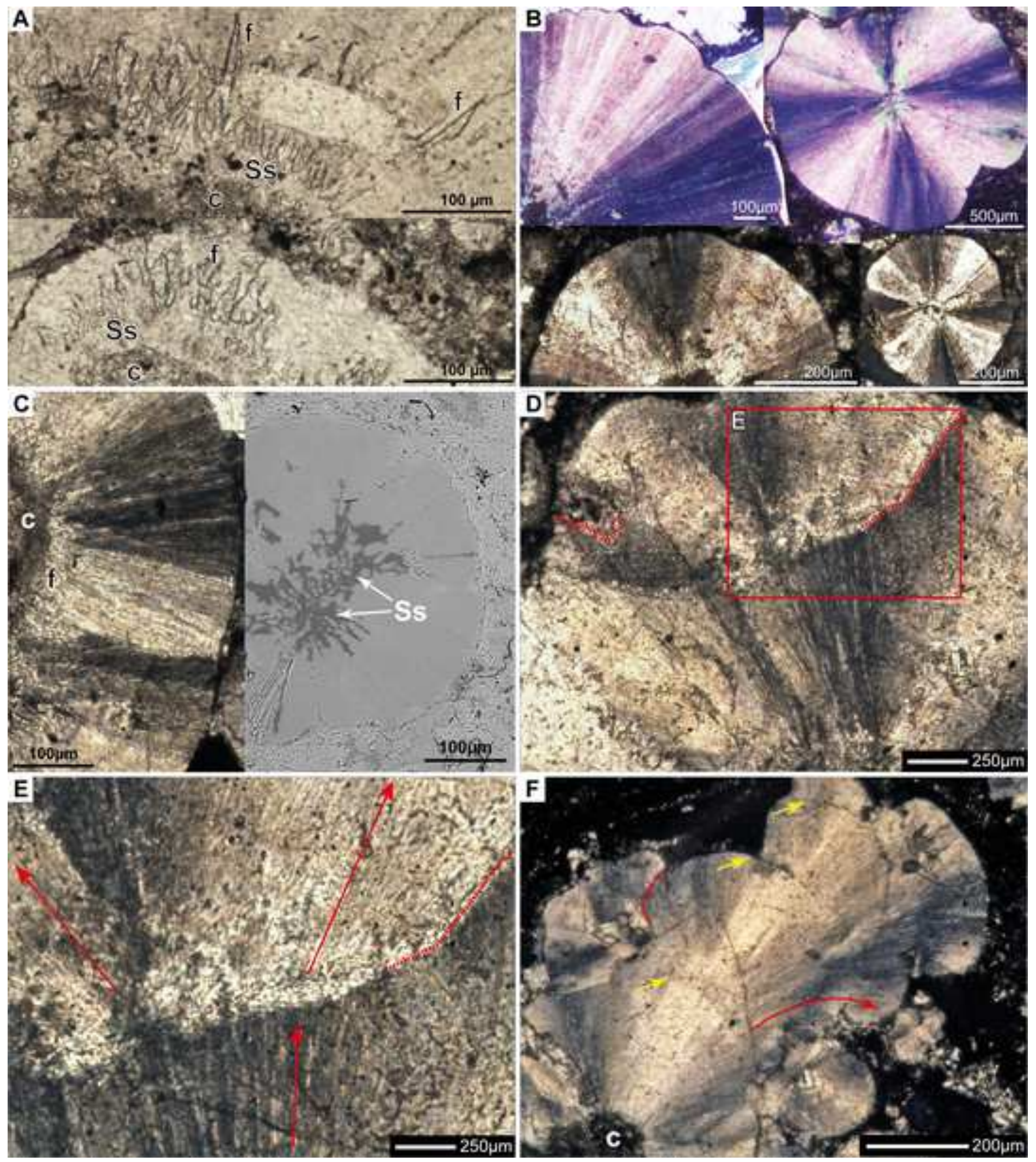
Click here to download high resolution image
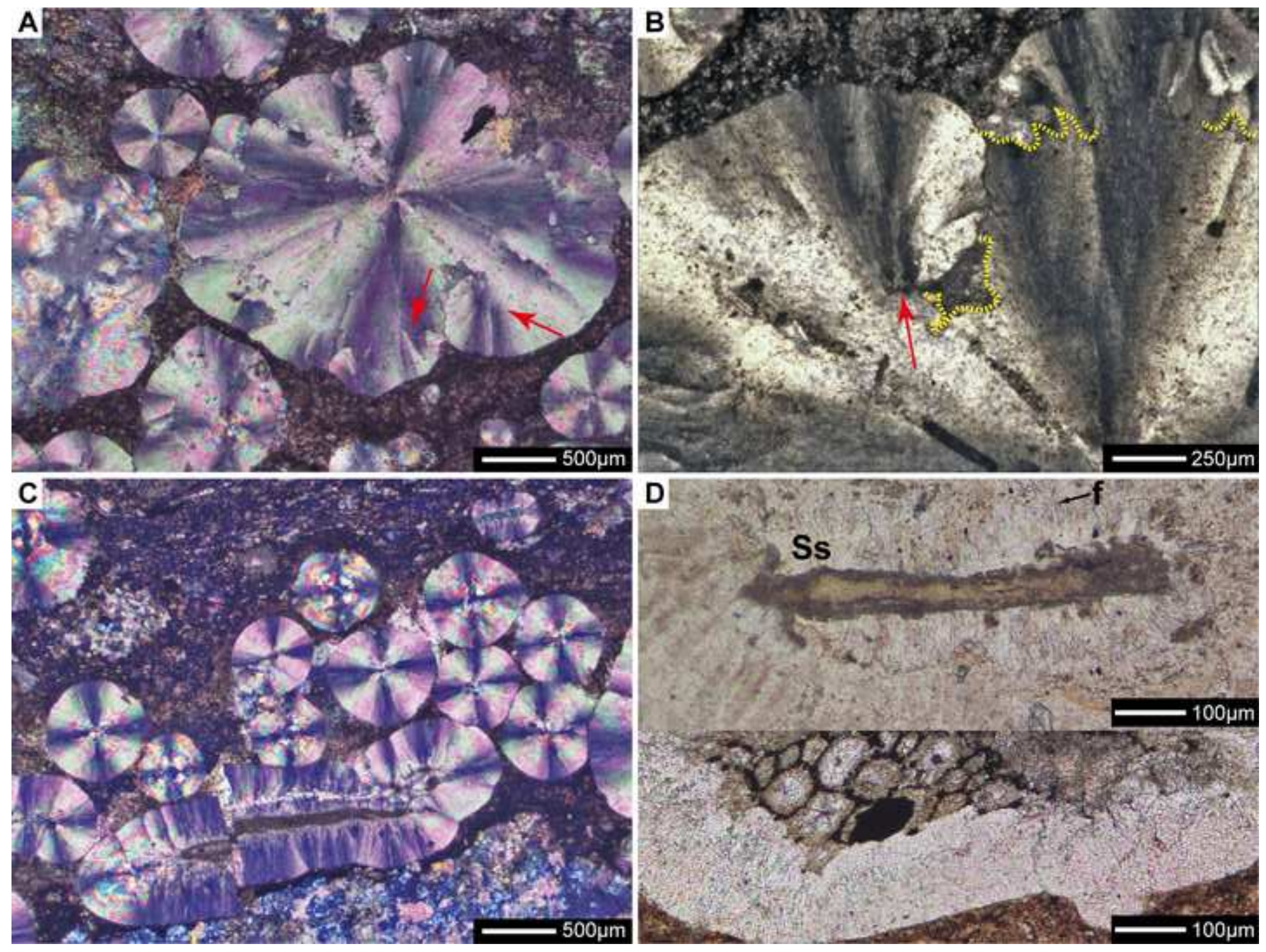


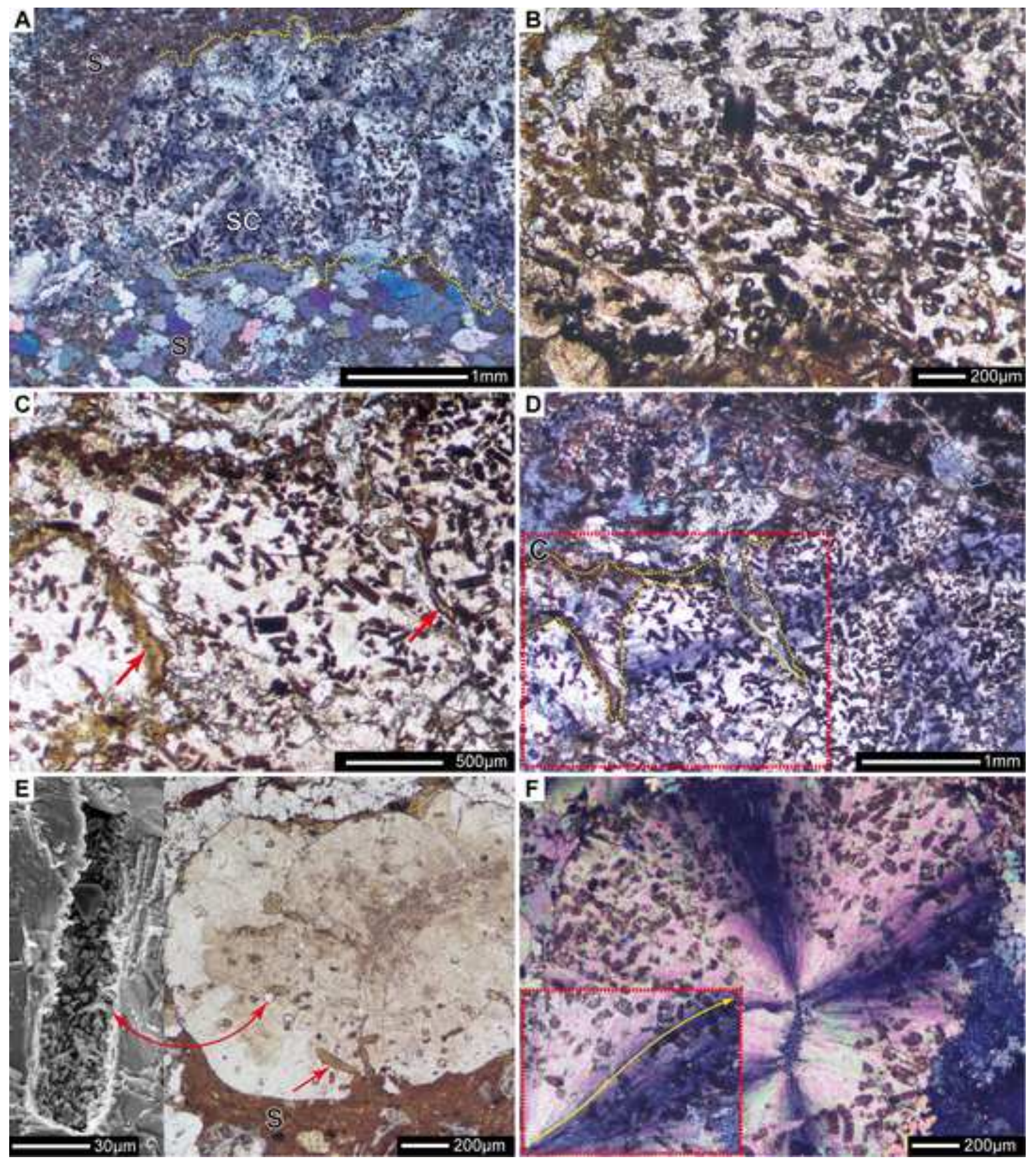


Click here to download high resolution image
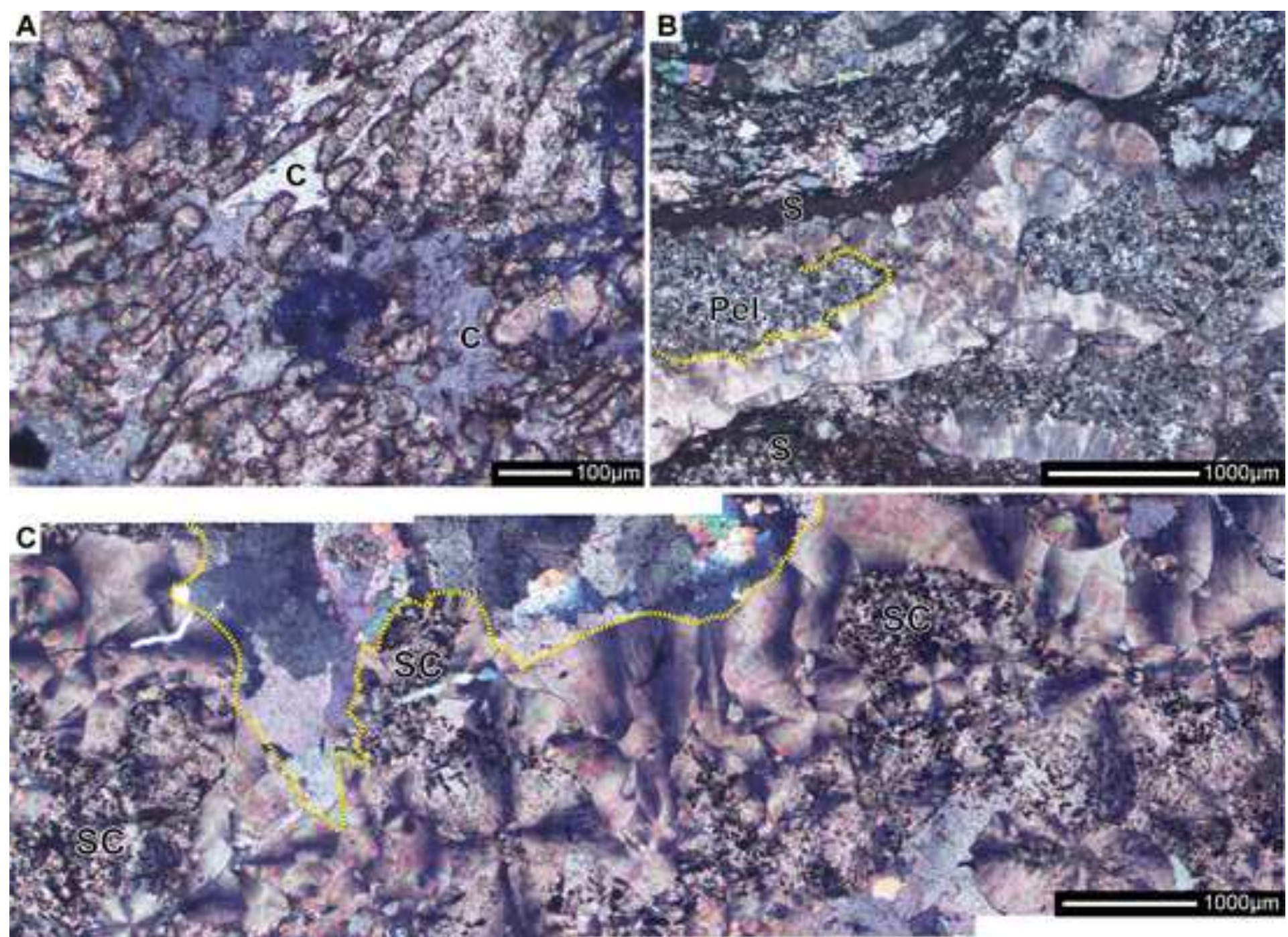

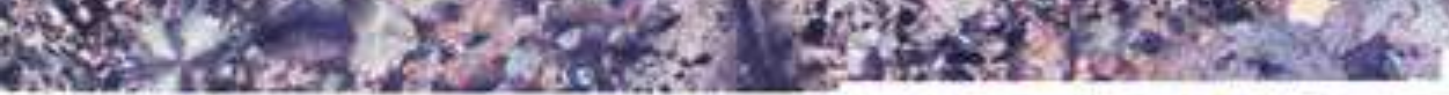
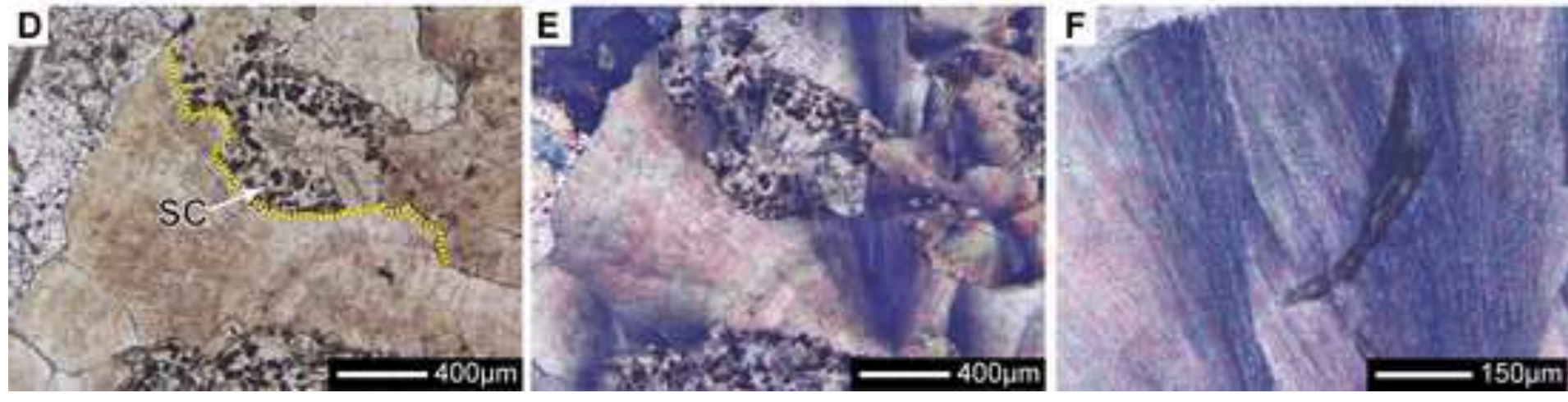
Figure 13

Click here to download high resolution image
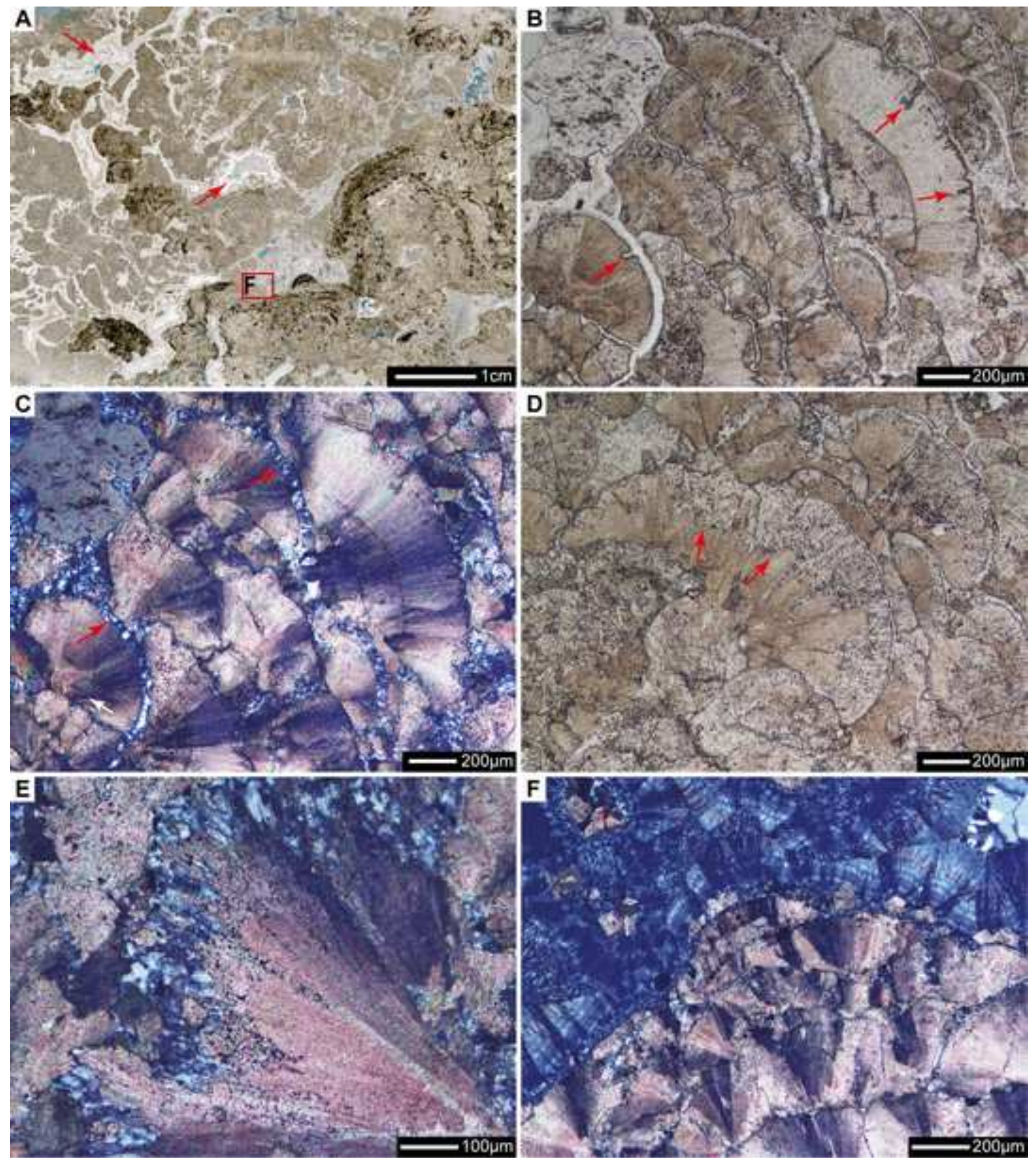


\section{Figure 14}

Click here to download high resolution image
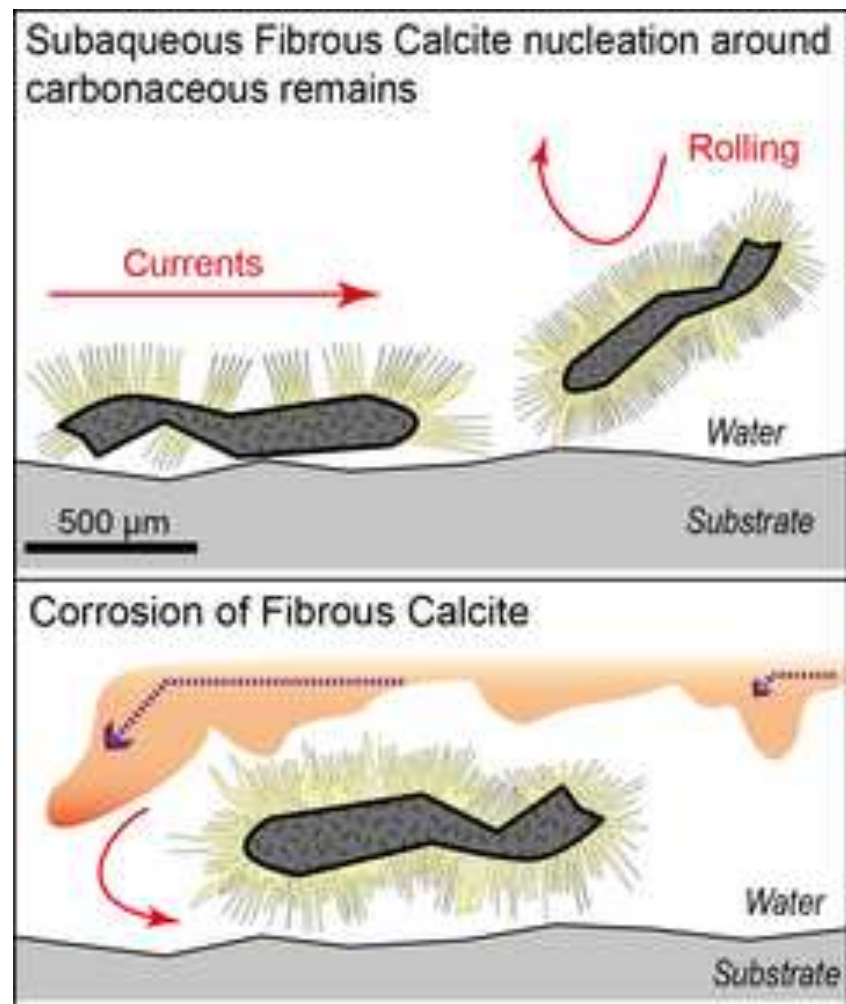

Spherulitic Calcite grew upon Fibrous Calcite

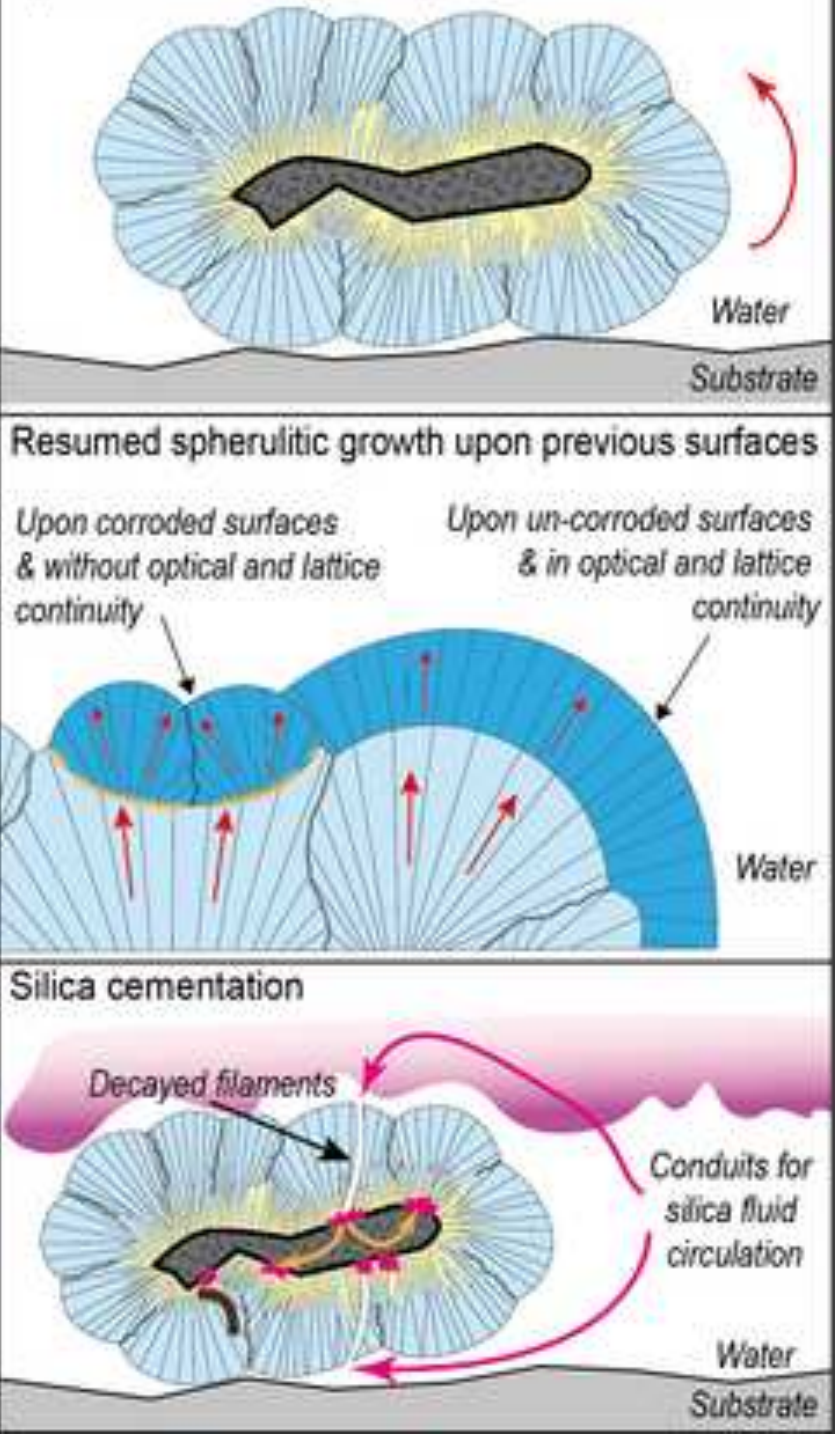


Figure 15

Click here to download high resolution image

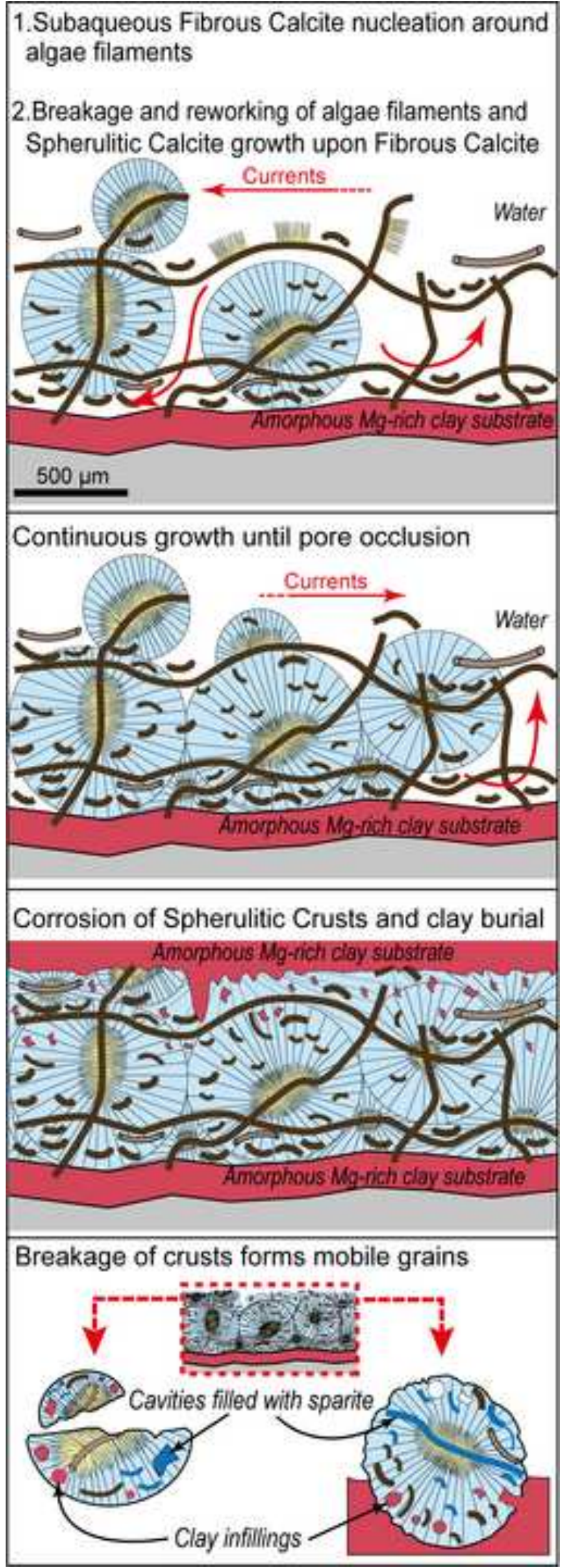


Subaqueous Spherulitic Calcite nucleation encrusting algae/ plant thallus

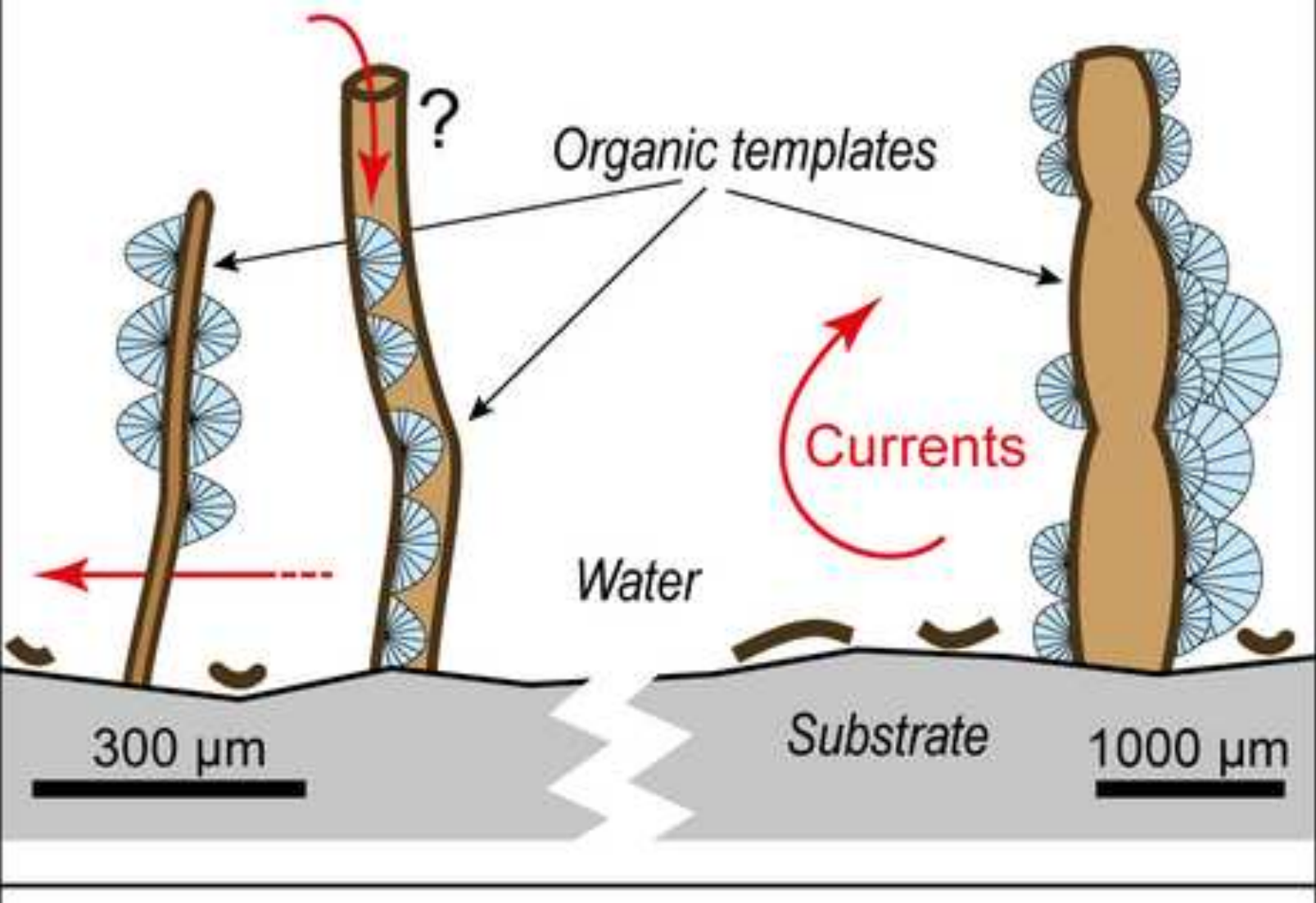

Reworking of the organic templates and dispersion forming Spherulitic Intraclasts
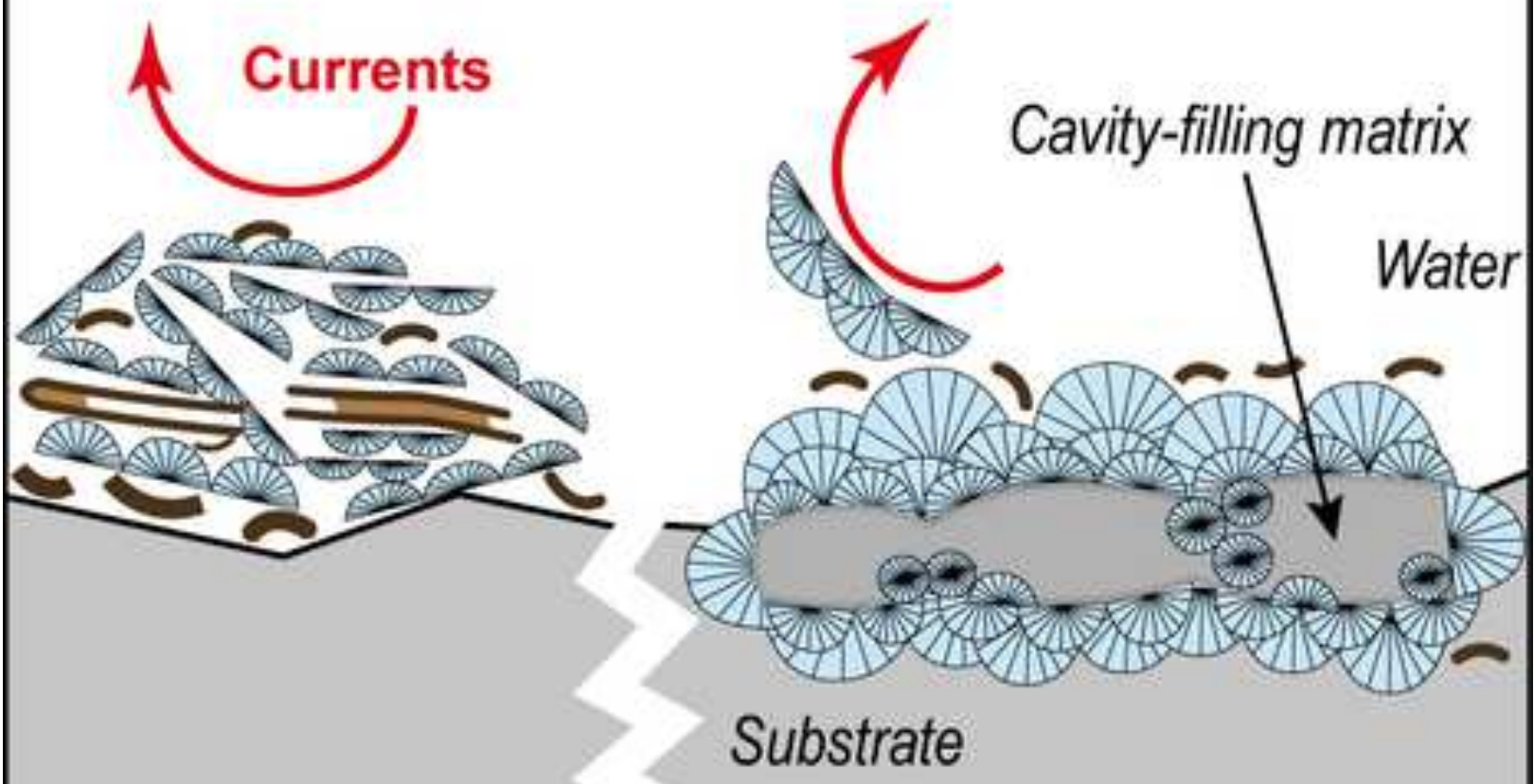


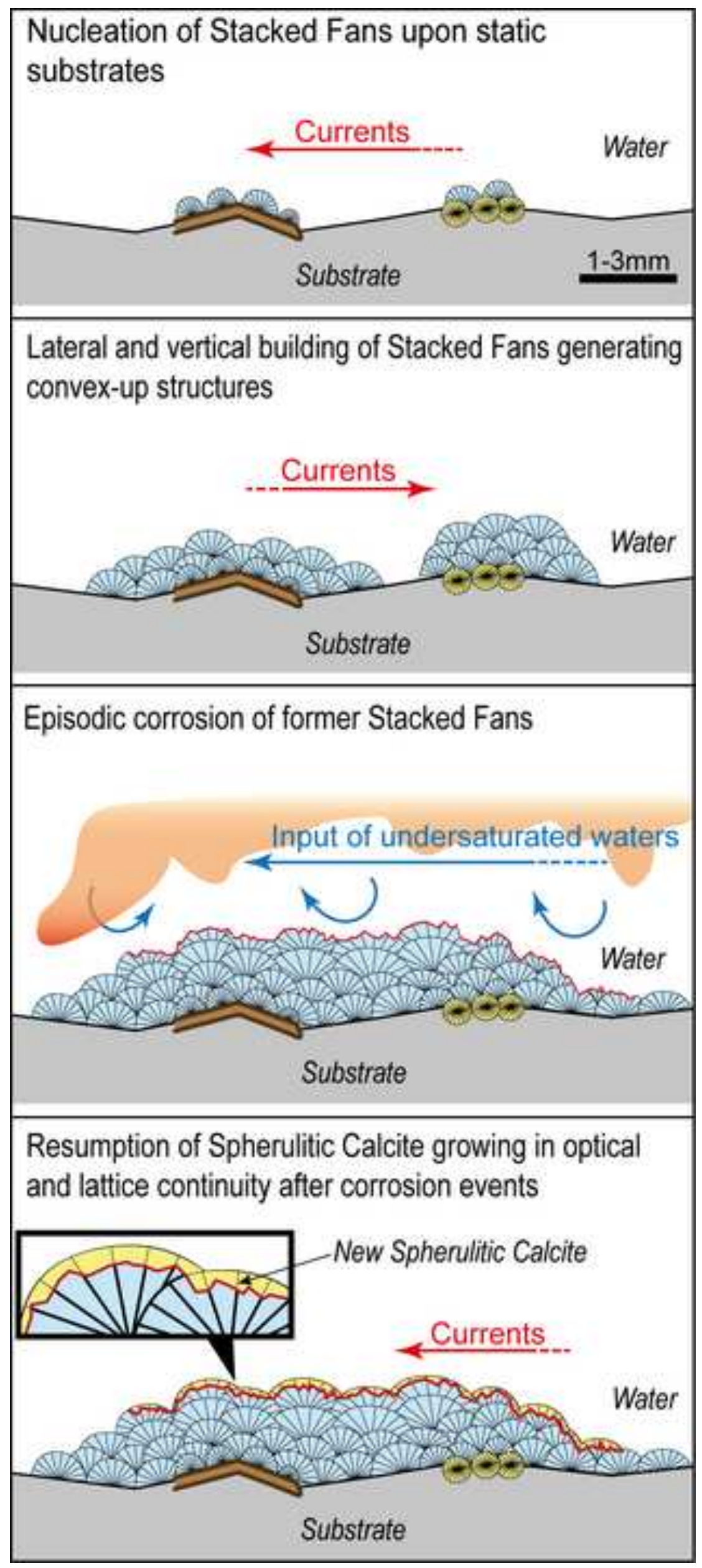


Click here to download high resolution image

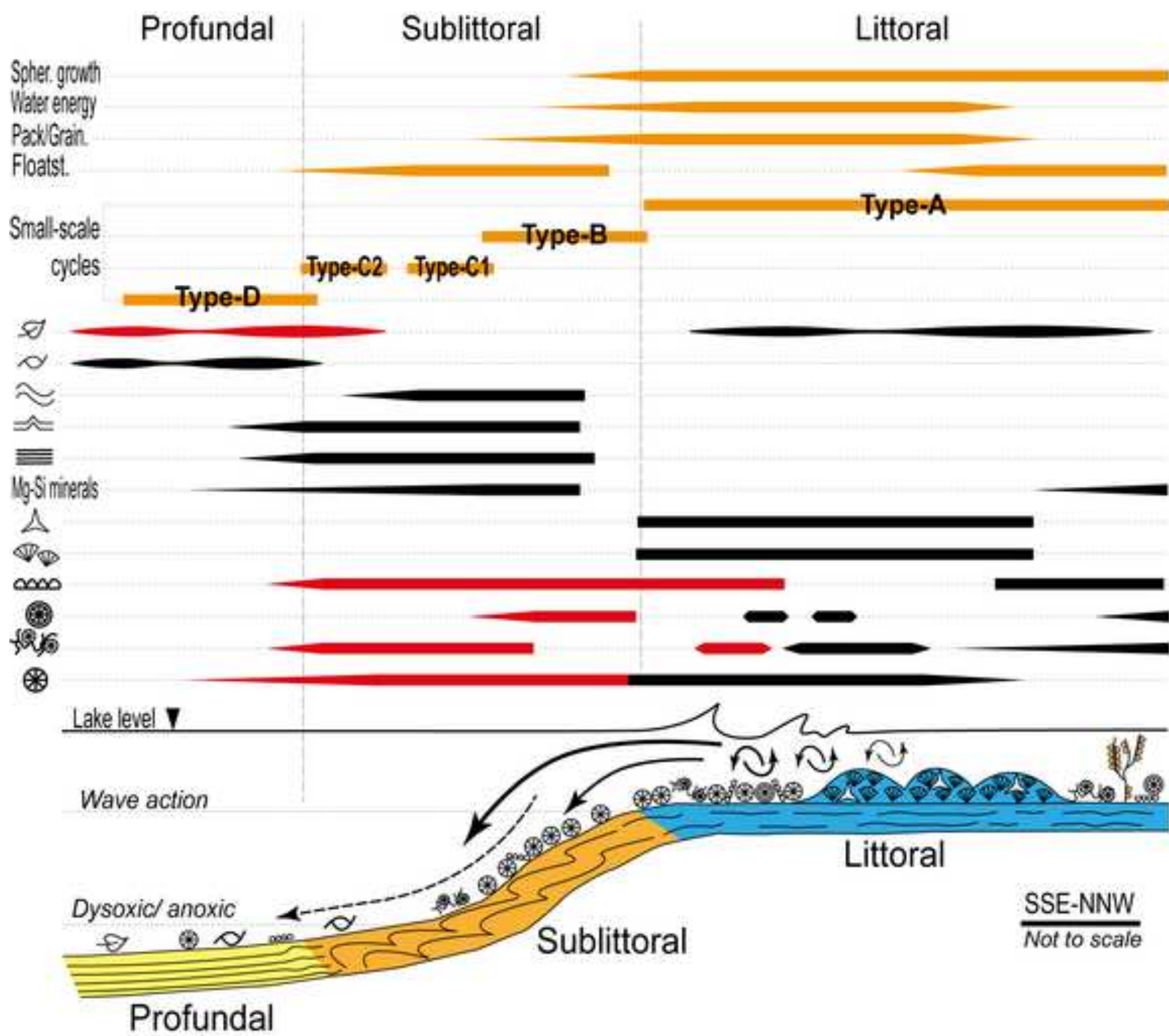




\begin{tabular}{|c|c|c|c|c|c|c|}
\hline $\begin{array}{l}\text { Laminites } \\
\text { Fig. } 4\end{array}$ & $\begin{array}{l}\text { Flat and tabular beds } \\
\text { with high lateral } \\
\text { continuity }(5 \text { to } 50 \mathrm{~cm}- \\
\text { thick, decametric lateral } \\
\text { extension) }\end{array}$ & $\begin{array}{l}\text { Repetitive alternation of } \\
\text { carbonate-rich layers (up } \\
\text { to } 4 \mathrm{~cm} \text {-thick) and } \\
\text { organic/ fine gained } \\
\text { silica-rich layers (up to } 3 \\
\mathrm{~cm} \text {-thick) }\end{array}$ & $\begin{array}{l}\text { Alternation of } \\
\text { carbonate, organic and } \\
\text { silica laminae }\end{array}$ & 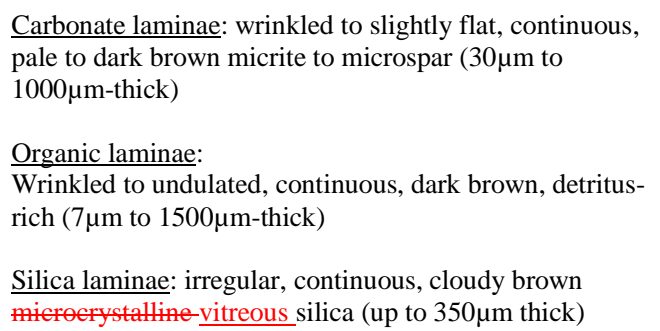 & $\begin{array}{l}\text { Plant/ Algae remains, } \\
\text { Fish scales, pellets, } \\
\text { Spherulitic Coated } \\
\text { Grains } \\
\text { Organic matter, Pellets, } \\
\text { Fish scales, Spherulitic } \\
\text { Coated Grains, Pyrite } \\
\text { framboids }\end{array}$ & $\begin{array}{l}\text { Laminites } \\
\text { Spherulitic Laminites }\end{array}$ \\
\hline $\begin{array}{l}\text { Grainstone- } \\
\text { packstone } \\
\text { Sspherulitic } \\
\text { grainstone- } \\
\text { packstone } \\
\text { grains, } \\
\text { intraclasts and } \\
\text { erusts } \\
\text { Fig.5a,b }\end{array}$ & $\begin{array}{l}\text { Discontinuous layers, } \\
\text { restricted continuity (5 to } \\
80 \mathrm{~cm} \text {-thick, decimetric } \\
\text { lateral extension) }\end{array}$ & Sub-cm layers & - & $\begin{array}{l}\text { Poorly to moderately sorted spherulitic grainstone- } \\
\text { packstone. Fine to coarse sand size, well-rounded to } \\
\text { angular grains. } \\
\text { Matrix of red-brown amorphous Mg-Si matrices-clay } \\
\text { (kaolinite-serpentine group) occasionally replaced by } \\
\text { ferroan blocky to granular calcite cements }\end{array}$ & $\begin{array}{l}\text { Spherulitic Coated } \\
\text { Grains, Spherulitic } \\
\text { Intraclasts, Spherulitic } \\
\text { Crusts, Volcanic clasts } \\
\text { - }\end{array}$ & Grainstone-packstone, \\
\hline $\begin{array}{l}\text { Shrubby } \\
\text { Spherulitic } \\
\text { cementstonecar } \\
\text { bonate build- } \\
\text { ups } \\
\text { Fig.5c tof }\end{array}$ & $\begin{array}{l}\text { Dome-shaped to } \\
\text { lenticular bodies (up to } 2 \\
\text { m-thick and } 3 \mathrm{~m} \text {-wide } \\
\text { decametric lateral } \\
\text { extension) }\end{array}$ & $\begin{array}{l}\text { Massive and indurated } \\
\text { 'clotted' bodies }\end{array}$ & $\begin{array}{l}\text { Pale white coloured } \\
\text { irregular cavities filled } \\
\text { with silica cements } \\
\text { (mm- to cm-sized) }\end{array}$ & See Stacked Fans (Table 2) & - & $\begin{array}{c}\text { 'Boundstone'Cementston } \\
\underline{\mathrm{e}}\end{array}$ \\
\hline $\begin{array}{l}\text { Volcanic and } \\
\text { intraclastic } \\
\text { calcareous tuffs } \\
\text { Fig.6a to d }\end{array}$ & $\begin{array}{l}\text { Layered bodies } \\
\begin{array}{l}(5 \mathrm{~cm}-\text { to } 5 \mathrm{~m} \text {-thick } \\
\text { decametric lateral }\end{array} \\
\text { extension) }\end{array}$ & - & $\begin{array}{l}\text { Pyroclastic texture } \\
\text { (lapilli) surrounded by a } \\
\text { chaotic shard } \\
\text { groundmass }\end{array}$ & $\begin{array}{l}\text { Lapilli: Porphyritic texture with phenocrysts floating in a } \\
\text { cryptocrystalline glassy matrix. Plagioclase, } \\
\text { Clinopyroxene (augite), Olivine, Magnetite. } \\
\text { Red-brown amorphous Mg-Si minerals are common }\end{array}$ & - & Basalt/ Basanite \\
\hline $\begin{array}{l}\text { Layered } \\
\text { earbonatesIntrac } \\
\text { lastic } \\
\frac{\text { wackestone- }}{\text { floatstone }} \\
\text { Fig.6e,f}\end{array}$ & $\begin{array}{l}\text { Continuous and slightly } \\
\text { nodular to tabular layers } \\
\text { (up to } 15 \mathrm{~cm} \text { thick, } \\
\text { decametric lateral } \\
\text { extension) }\end{array}$ & $\begin{array}{l}\text { Slumps and convolute } \\
\text { beds, graded beds }\end{array}$ & - & Wackestone-floatstone of contorted laminae intraclasts & $\begin{array}{l}\text { Intraclastic laminae, } \\
\text { peloids, ostracods, } \\
\text { minor Spherulitic } \\
\text { Coated Grains, pyrite } \\
\text { framboids }\end{array}$ & Wackestone - floatstone \\
\hline $\begin{array}{l}\text { Shales } \\
\text { Fig. 6e }\end{array}$ & $\begin{array}{l}\text { Dark blue-grey, organic- } \\
\text { rich shale/clay (up to } \\
6 \mathrm{~m} \text {-thick, decametric } \\
\text { lateral extension) }\end{array}$ & $\begin{array}{l}\text { Ironstone bands and } \\
\text { concretions in thin } \\
\text { horizons }\end{array}$ & - & - & $\begin{array}{l}\text { Bivalves, Ostracods, } \\
\text { Arthropod cuticles, } \\
\text { Foliage remains, } \\
\text { Trunks, Fish scales, } \\
\text { Vertebrates }\end{array}$ & Shale \\
\hline
\end{tabular}


Vegetated remains (lycopsids, ferns or gymnosperms), algae, volcanic remains, and peloids acting as cores

Fibrous Calcite

Spherulitic Coated Grains

Fig. 4, 5, 9, 10
Facies 1, 2, 4 and 5

Subhedral Silica

Spherulitic Calcite

$\underline{\text { Subhedral Silica }}$

Botryoidal Calcite
Type $1(85 \%)$ - Circular and spheroidal grain morphologies, rounded to sub-rounded corners and edges, and irregular and/or abraded outlines. Build upon arcuate and spheroidal nucleus (50 to $700 \mu \mathrm{m}$-length). Spherulitic Calcite fabrics common (sweeping extinction)

Type $2(15 \%)$ - Elongated and non-spheroidal grain morphologies, and similar roundness and irregularities. Build upon irregular and elongated nucleus (up to $4 \mathrm{~mm}$-length). Spherulitic Botryoidal-Calcite fabrics common (sweeping extinction)

Spherulitic and Botryoidal Calcite crystals experience deflection in later stages of growth. Corrosion features are common

\begin{tabular}{|c|c|c|}
\hline \multirow{2}{*}{$\begin{array}{l}\text { Spherulitic Crusts } \\
\text { Fig. } 11\end{array}$} & \multirow[t]{2}{*}{ Facies 1, 2 and 4} & $\begin{array}{l}\text { Fibrous Calcite } \\
\text { Subhedral Silica }\end{array}$ \\
\hline & & Spherulitic Calcite \\
\hline & & $\underline{\text { Subhedral Silica }}$ \\
\hline
\end{tabular}

Facies 1, 2 and 4 Fig. 12 Calcite

Spherulitic Calcite encapsulating fragments ( $50 \mu \mathrm{m}$ in diameter) and whole specimens (at least $4 \mathrm{~mm}$ in length) of green algae filaments and sporadic plant remains. Sweeping extinction

Fragments of Spherulitic Crusts display polished outlines and decayed filament inclusions are now filled by amorphous Mg-Si phases-minerals or calcite cements

Corrosion features are common. Resultant cavities can be filled by clay or blocky calcite cement

Type 1 (90\%) - Laterally stacked Spherulitic Botryoidal-Calcite (up to 20-30 $\mu \mathrm{m}$ in width) with flat and smooth bases (100 to $500 \mu \mathrm{m}$ long). Sweeping extinction

Cype 2 (10\%) - Tubiform objects (4mm in length, $2 \mathrm{~mm}$ in width) with outer layers made of composite laterally and vertically stacked Spherulitic Botryoidat-Calcite (100 to $500 \mu \mathrm{m}$ in width). Sweeping extinction

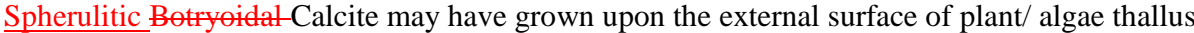
Corrosion cavities are common and can be filled by Spherulitic Crusts

\section{Stacked fans}

Fig. 13
Facies 3

Laterally and vertically-stacked 'shrub-like' Spherulitic Botryoidal Calcite (100 to 1000 $\mu \mathrm{m}$ thick, and 100 to $3000 u \mathrm{~m}$ width). Sweeping extinction

Spherulitic BotryoidatCalcite have scalloped dissolution pits and vertical cracks (up to $200 \mu \mathrm{m}$-length) and are outlined by thin and continuous silica laminae (10 to $50 \mu \mathrm{m}$-thick) 